\title{
Exploring Single-Payer Alternatives for Health Care Reform
}

Jodi L. Liu

This document was submitted as a dissertation in May 2016 in partial fulfillment of the requirements of the doctoral degree in public policy analysis at the Pardee RAND Graduate School. The faculty committee that supervised and approved the dissertation consisted

of Robert H. Brook (Chair), Christine Eibner, and Jeffrey Wasserman.

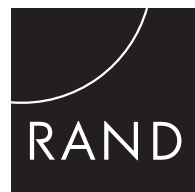

PARDEE RAND GRADUATE SCHOOL 
For more information on this publication, visit http://www.rand.org/pubs/rgs_dissertations/RGSD375.html

Published by the RAND Corporation, Santa Monica, Calif.

(C) Copyright 2016 RAND Corporation

RAND $^{\circledR}$ is a registered trademark

\section{Limited Print and Electronic Distribution Rights}

This document and trademark(s) contained herein are protected by law. This representation of RAND intellectual property is provided for noncommercial use only. Unauthorized posting of this publication online is prohibited. Permission is given to duplicate this document for personal use only, as long as it is unaltered and complete. Permission is required from RAND to reproduce, or reuse in another form, any of its research documents for commercial use. For information on reprint and linking permissions, please visit www.rand.org/pubs/permissions.html.

The RAND Corporation is a research organization that develops solutions to public policy challenges to help make communities throughout the world safer and more secure, healthier and more prosperous. RAND is nonprofit, nonpartisan, and committed to the public interest.

RAND's publications do not necessarily reflect the opinions of its research clients and sponsors.

Support RAND

Make a tax-deductible charitable contribution at

www.rand.org/giving/contribute

www.rand.org 


\section{Abstract}

The Affordable Care Act (ACA) has reduced the number of uninsured and established new cost containment initiatives. However, interest in more comprehensive health care reform such as a single-payer system has persisted. Definitions of single-payer systems are heterogeneous, and estimates of the effects on spending vary. The objectives of this dissertation were to understand single-payer proposals and to estimate health care spending under single-payer alternatives in the United States.

Single-payer proposals are wide-ranging reform efforts spanning financing and delivery, but vary in the provisions. I modeled two sets of national scenarios - one labeled comprehensive and the other catastrophic - and compared insurance coverage and spending relative to the ACA in 2017. First, I estimated the effects of utilization and financing changes, and then I added the effects of "other savings and costs" relating to administration, drug and provider prices, and implementation.

Due to coverage of all legal residents and low cost sharing and prior to adjusting for other savings and costs, the comprehensive scenario increased national health care expenditures by $\$ 435$ billion and federal expenditures by $\$ 1$ trillion relative to the ACA. The range of the net effect of the other savings and costs in the literature was $\$ 1.5$ trillion in savings to $\$ 140$ billion in costs, with a mean estimate of $\$ 556$ billion in savings. If this mean estimate was applied to the comprehensive scenario, national expenditures would be $\$ 121$ billion lower but federal expenditures would still be $\$ 446$ billion higher relative to the ACA. The catastrophic scenario also covered all legal residents but increased overall cost sharing, resulting in a reduction in national expenditures by $\$ 211$ billion and federal expenditures by $\$ 40$ billion even before adjusting for other savings and costs. Average household spending on health care in both sets of scenarios could be more progressive by income than spending under the ACA.

I also developed an interactive, web-based cost tool that allows the savings and cost assumptions to be adjusted by any user. As the debate on how to finance health care for all Americans continues, this study provides increased transparency about economic evaluations of health care reform. 



\section{Table of Contents}

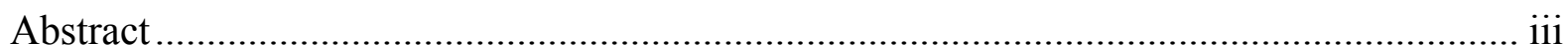

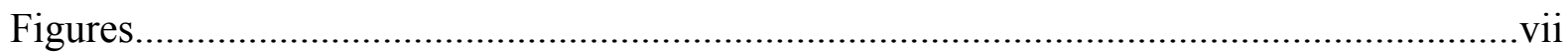

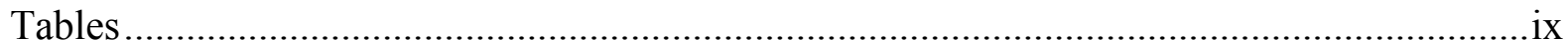

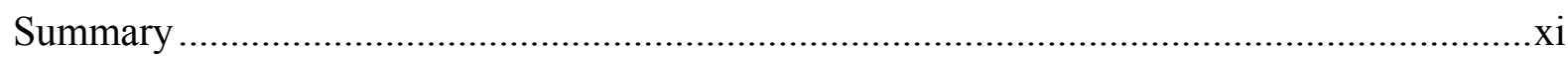

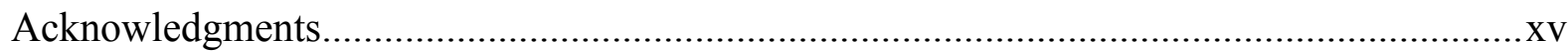

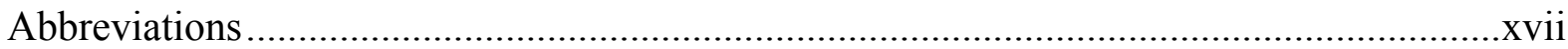

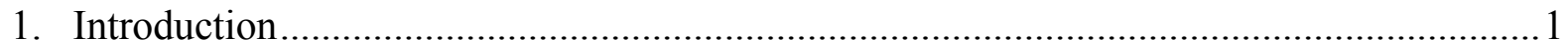

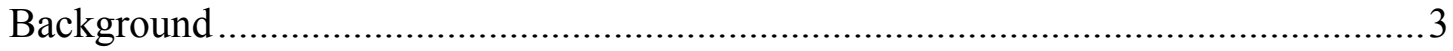

Types of Health Care Systems ........................................................................ 3

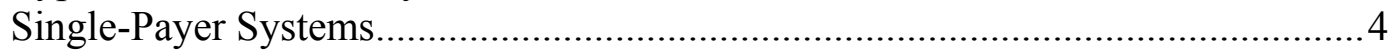

Single-Payer Health Care Reform in the U.S. ................................................. 6

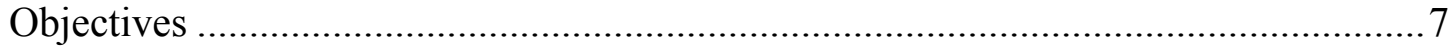

2. Single-Payer Definitions and Proposals in the U.S. Context.......................................... 9

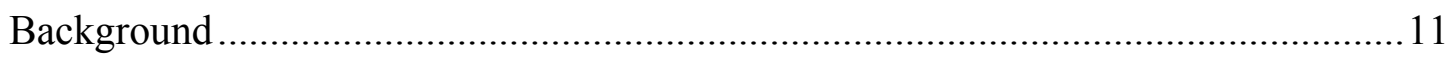

Conceptual Framework of Health System Functions ....................................... 11

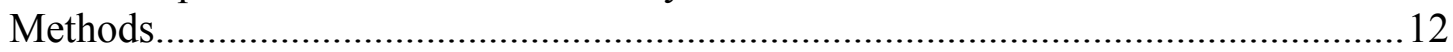

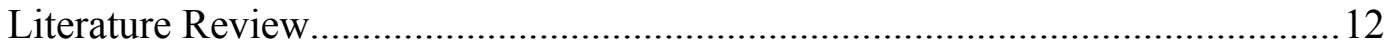

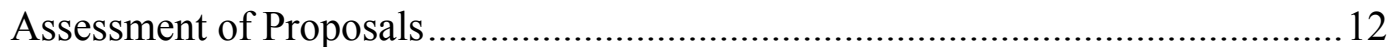

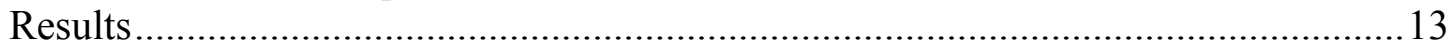

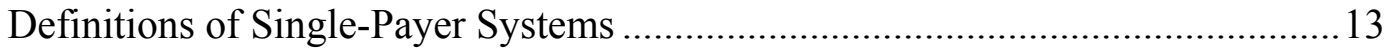

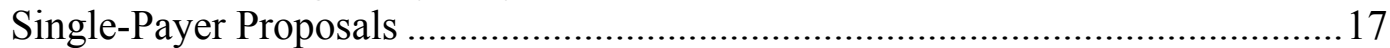

Breadth across Health Care System Functions .................................................29

Provisions towards Increased Access, Improved Quality, and Reduced Costs ..... 31

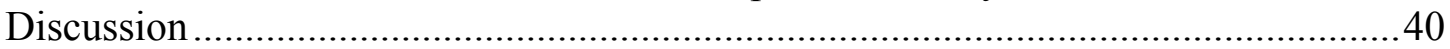

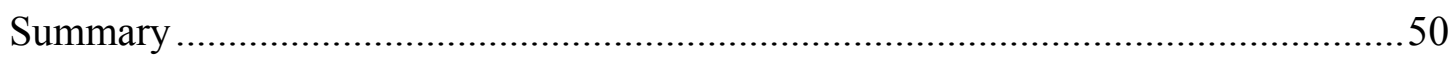

3. Health Care Coverage and Spending under National Single-Payer Alternatives ..............52

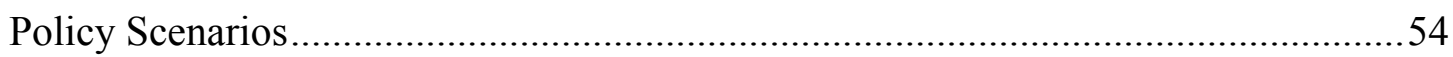

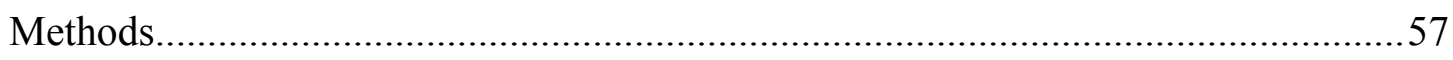

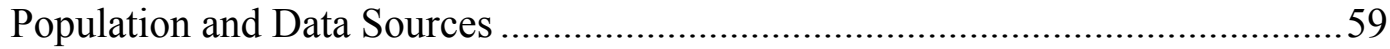

Behaviors in the Microsimulation..................................................................6 60

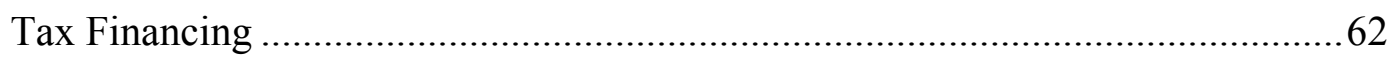

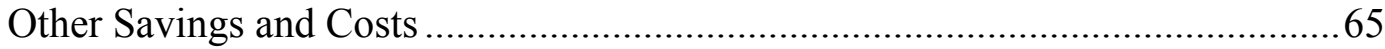

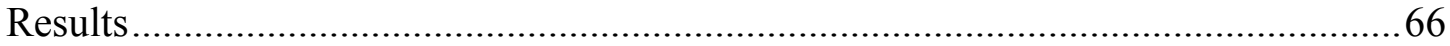

Effects of Cost Sharing and Financing on Coverage and Spending .....................66

Effects of Other Savings and Costs ................................................................. 73

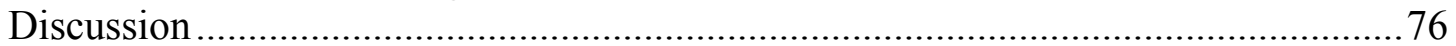




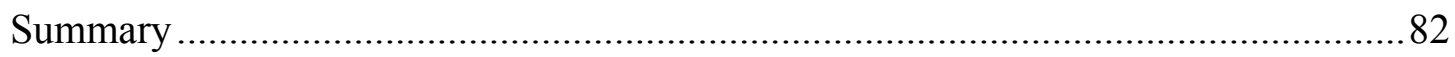

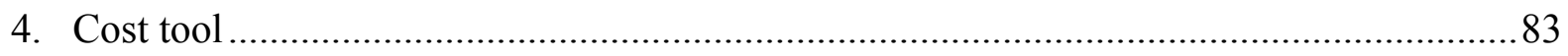

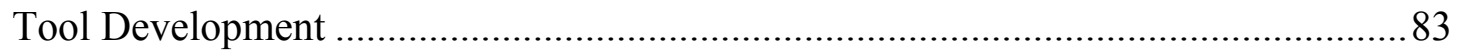

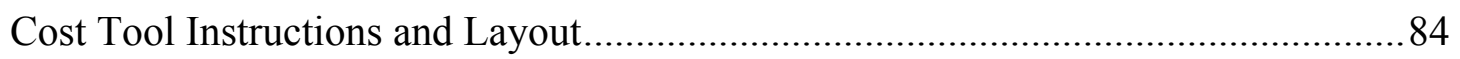

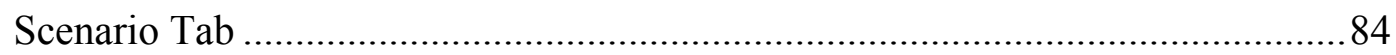

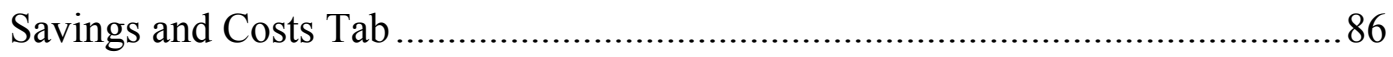

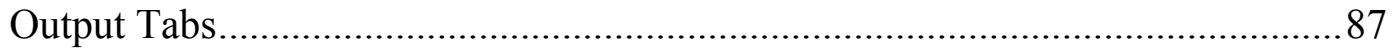

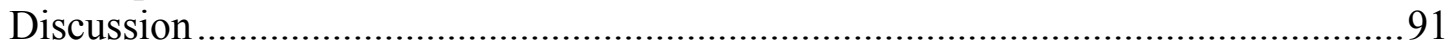

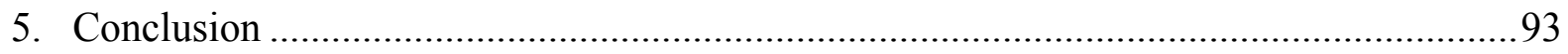

Appendix A: Proposal Provisions for Access, Quality, and Cost Reduction ....................... 100

Appendix B: Technical Details of Modeling Assumptions ................................................ 115

Firm Offers and Spending without the Tax Exclusion ........................................ 115

Private Premium Calculation in Catastrophic Scenarios ........................................ 115

Existing Federal Income Taxes Supporting Health Care ........................................ 118

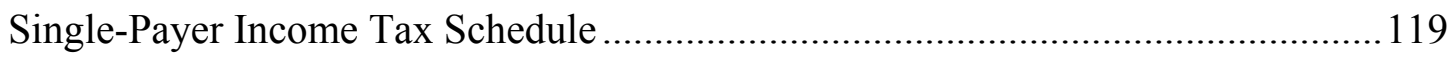

Trading Volume Assumption with the Single-Payer Securities Transaction Tax ..... 120

Appendix C: Alternative Comprehensive Single-Payer Scenario .................................... 121

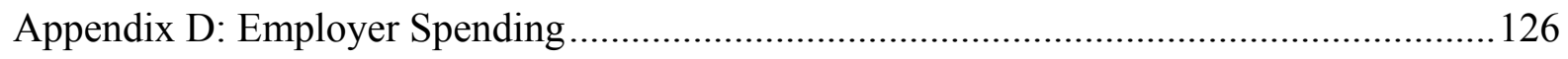

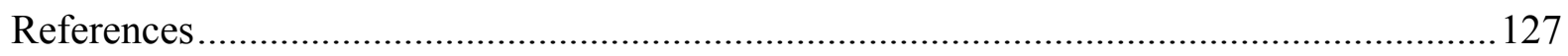




\section{Figures}

Figure 2.1. Conceptual Framework of a Health System..................................................... 11

Figure 2.2. Breadth of Proposals across Health Care System Functions...............................30

Figure 2.3. Common Access, Quality, and Cost Provisions in the Proposals ........................ 31

Figure 3.1. Conceptual Framework of Health Care Financing ............................................58

Figure 3.2. National Health Care Spending by Source of Revenue in 2017 ........................68

Figure 3.3. Average Household Spending on Health Care in 2017 .................................... 71

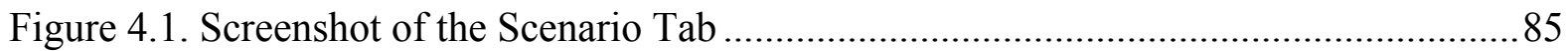

Figure 4.2. Screenshot of Sample Panels in the Savings \& Costs Tab .................................87

Figure 4.3. Screenshot of the National Spending $\mathrm{Tab}$..................................................... 88

Figure 4.4. Screenshot of the Federal Spending Tab ......................................................... 89

Figure 4.5. Screenshot of the Household Spending Tab................................................. 90

Figure 4.6. Screenshot of the Coverage Tab .................................................................. 90

Figure B.1. Private Insurance Coverage below the Catastrophic Deductible......................116

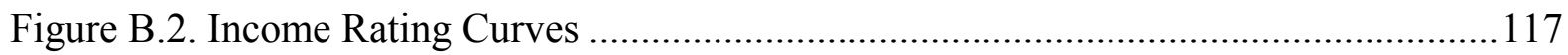

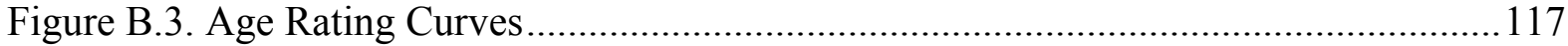

Figure C.1. National Health Care Spending by Source of Revenue in 2017: Alternative Comprehensive Scenario

Figure C.2. Average Household Spending on Health Care in 2017: Alternative Comprehensive Scenario. 



\section{Tables}

Table 1.1. Examples of Health Care Systems with a Single Payer........................................5

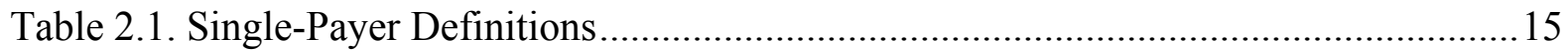

Table 2.2. Characteristics of Single-Payer Proposals .......................................................20

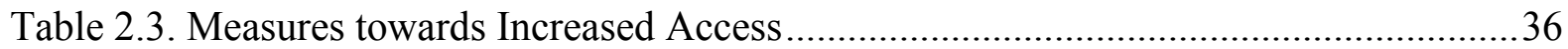

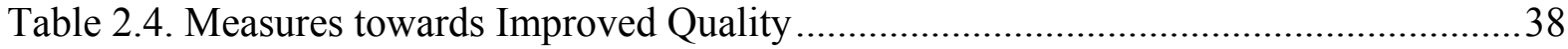

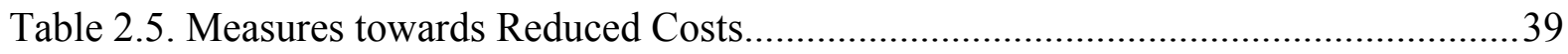

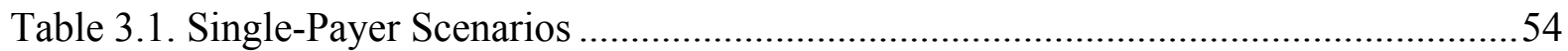

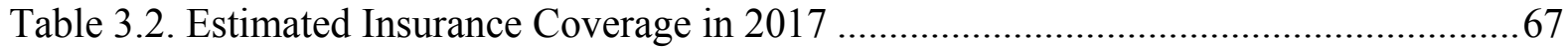

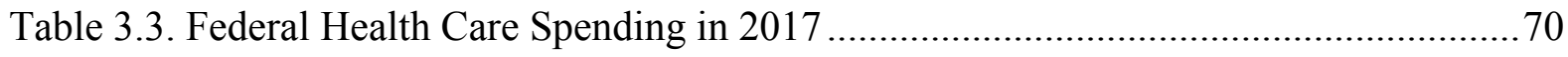

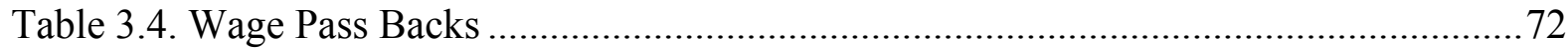

Table 3.5. Ranges of Other Savings and Cost Estimates............................................. 75

Table 3.6. National and Federal Spending Before and After Savings and Cost Assumptions 76

Table A.1 Measures to Improve Access, Quality, and Cost Reduction...............................100

Table C.1. Alternative Comprehensive Scenario............................................................... 122

Table C.2. Federal Health Care Spending in 2017: Alternative Comprehensive Scenario ... 124

Table D.1. Employer Spending on Health Care in 2017 ............................................... 126 



\section{Summary}

The Patient Protection and Affordable Care Act (ACA) has reduced the number of uninsured and established new cost containment initiatives, but gaps in insurance and high health care costs remain. As such, interest in more comprehensive health care reform including single-payer systems has persisted. However, there is no agreed upon definition of a single-payer system: it varies, for example, by the type of payer, eligibility, benefits, cost sharing, and cost controls. Furthermore, there is no consensus on the impact of a single payer on health care spending. The purpose of this dissertation is to explore the landscape of single-payer definitions and proposals, and to estimate spending under single-payer alternatives.

Single-payer definitions are heterogeneous and range from broad to narrow. Most definitions characterize a single-payer system as a system with one entity that collects funds and pays for health care on behalf on an entire population. Some definitions delineate details on both the financing and delivery of care, e.g., restricting single-payer systems to those with care delivered by private providers, while others refer to the potential for administrative efficiencies and cost controls. In the U.S. context, I found that a definition that allows for single-payer systems within a broader U.S. system by restricting the scope of a single-payer system by a defined population, benefit package, and geography is useful because it is inclusive of systems relevant for the U.S. yet provides some characteristics by which the system can be specified. This definition includes federal and state bills that have been proposed in legislatures, and includes plans providing a subset of services or plans with cost sharing.

I explored the contents of health care reform proposals that involve a single payer by assessing the proposals on the breadth across health care system functions and the aims to 
improve access, quality, and cost reduction in the system. I reviewed 25 proposals including federal and state bills introduced in recent years. The proposals typically call for wide-ranging reform beyond simply the number of payers, and include a diverse array of provisions addressing improvements to access, quality, and cost containment. Most of the proposals are comprehensive reform plans and include some provisions that are not unique to single-payer systems. Common provisions to address access, quality, and cost include comprehensive benefits, little to no cost sharing, patient choice of providers, provider guidelines and quality standards, electronic medical records and billing systems, drug and medical supply formularies, global budgets, and thresholds for administrative costs.

I analyzed two sets of national single-payer scenarios - comprehensive and catastrophic relative to predicted spending and coverage under the ACA in 2017. The comprehensive scenarios are based on the American Health Security Act (S. 1782, 113th Congress), in which all legal residents have coverage with little to no cost sharing and duplication by private insurance would be prohibited. The catastrophic scenarios are based on the Health-Insurance Solution, in which Medicare and Medicaid continue and all other legal residents have income-dependent coverage; options allowing supplemental private insurance were considered.

I estimated coverage and expenditures in response to the single-payer plans and financing using the RAND Corporation's Comprehensive Assessment of Reform Efforts (COMPARE) microsimulation model. For "other savings and costs" resulting from administrative efficiencies, changes in drug and provider payment, and implementation, I summarized a range of possible effects from the literature and incorporated the estimates into an interactive cost tool.

Relative to the estimated spending under the ACA in 2017 and prior to adjusting for the "other savings and costs," coverage of all legal residents and low cost sharing in the 
comprehensive scenario increased national health care expenditures by $\$ 435$ billion and increased federal health care expenditures by $\$ 1$ trillion. The overall lower generosity of the catastrophic scenario reduced national health care expenditures by $\$ 211$ billion and federal expenditures by $\$ 40$ billion relative to the ACA, while still providing all legal residents with some level of coverage. The design of both sets of scenarios can be modified: I adjusted the plan generosity and the tax levels in the comprehensive scenarios to address the financing deficit, and I estimated options for voluntary private insurance to supplement the catastrophic plan as variations to the catastrophic scenarios. The financing plans in both sets of scenarios could be designed such that average household spending on health care as a share of income would be more progressive than spending under the ACA.

The mean estimate of the net effect of the "other savings and costs" (i.e., administrative costs, drug and provider prices, and implementation costs) on national health care expenditures was $\$ 556$ billion in savings, with a range from over $\$ 1.5$ trillion in savings to $\$ 140$ billion in costs. If a single-payer system was able to achieve substantial administrative savings and lower prices, expenditures could be reduced significantly. Rather than produce a single set of static estimates based on relatively weak evidence for these savings and costs, I developed an interactive cost tool that allows users to adjust the savings and cost assumptions in real-time and view the impact on spending. The tool allows for increased transparency of how each effect influences overall spending and can be adapted as new evidence emerges.

Acknowledgment of what is considered a single-payer system and the characteristics that are variable can help shape a more nuanced policy debate on specific reform proposals rather than ambiguous concepts. Further research on possible pathways to a single-payer system and estimates of its impact is needed to support decision-making on future health care reform efforts. 
As the debate on how to finance health care for all Americans continues, the results of this study provide increased transparency about economic evaluations of health care reform policies and may be useful to the American public and policymakers. 


\section{Acknowledgments}

I thank my dissertation committee - Robert H. Brook, Christine Eibner, and Jeffrey Wasserman - for their invaluable guidance and support throughout this work. I am incredibly grateful that they encouraged me to think big and pushed for rigor and clarity. I also thank Arleen Leibowitz for serving as my outside reader and providing insightful comments. I am grateful to Sarah A. Nowak and Chapin White for their advice and discussions on the technical details of the modeling work. Dana Goldman and Kip Hagopian were generous with their time in discussing their proposal and providing feedback.

This dissertation was made possible by funding support through the generosity of anonymous donors. 



\section{Abbreviations}

ACA

$\mathrm{ACO}$

AGI

ASPE

AV

$\mathrm{CBO}$

CHIP

CMS

COMPARE

ERISA

ESI

FPL

GAO

HHS

HRET

IPAB

IRS

KFF

MEPS-HC

NBER

NHEA

NICE

NIIT

OOP

PNHP

SIPP

SOA
Affordable Care Act

accountable care organization

adjusted gross income

Assistant Secretary for Planning and Evaluation

actuarial value

Congressional Budget Office

Children's Health Insurance Program

Centers for Medicare and Medicaid Services

Comprehensive Assessment of Reform Efforts

Employee Retirement Income Security Act

employer-sponsored insurance

federal poverty level

Government Accountability Office (formerly General Accounting Office)

Department of Health and Human Services

Health Research Educational Trust

Independent Payment Advisory Board

Internal Revenue Service

Kaiser Family Foundation

Medical Expenditure Panel Survey - Household Component

National Bureau of Economic Research

National Health Expenditure Accounts

National Institute for Health and Care Excellence

Net Investment Income Tax

out-of-pocket

Physicians for a National Health Program

Survey on Income and Program Participation

Society of Actuaries 



\section{Introduction}

The Patient Protection and Affordable Care Act (ACA) as modified by the Health Care and Education Reconciliation Act of 2010 is the most substantial health care reform legislation since Medicare and Medicaid were enacted in 1965. The ACA has reduced the number of uninsured (Office of the Assistant Secretary for Planning and Evaluation, 2016; Centers for Medicare \& Medicaid Services, 2016a) and demonstration projects to improve quality and reduce costs are underway. However, insurance levels under the ACA fall short of universal coverage, with 27 million individuals estimated to be uninsured in 2025 (Congressional Budget Office, 2015c). Although an array of cost containment initiatives and demonstrations are proceeding, these models are still in early development phases and their effectiveness remains to be seen. ${ }^{1}$ Given these shortfalls and uncertainties, interest in more comprehensive health care reform has persisted, and debates on health care reform continue as the nation strives to achieve the "Triple Aim" of improved care experience, improved population health, and reduced per capita health care costs (Berwick, Nolan and Whittington, 2008).

The U.S. has the highest per capita health care costs among high-income countries, spending nearly twice as much or more on health care, yet fares poorly on health outcomes (Organization of Economic Cooperation and Development, 2013b). In addition, the U.S. stands out for its prevalence of the uninsured and underinsured (Organization of Economic Cooperation and Development, 2013a).

While most other peer countries achieve universal or near universal health insurance coverage, 47 million Americans were estimated to be uninsured prior to the ACA (Garfield,

\footnotetext{
${ }^{1}$ The cost containment strategies are not exclusive to certain payers and may be used within a single-payer system. 
Licata and Young, 2014). Although 9 to 10 million people were newly insured in the first year of the ACA (Sommers et al., 2014; Martinez and Cohen, 2014; Carman and Eibner, 2014; Collins, Rasmussen and Doty, 2014) and an estimated 20 million people have gained coverage between 2010 and early 2016 (Uberoi, Finegold and Gee, 2016), universal coverage will not be reached under the ACA. Even with the implementation of the ACA, 27 million individuals are projected to still be uninsured by 2025 (Congressional Budget Office, 2015c). Individuals remain uninsured for a variety of reasons, including the gap between Medicaid eligibility (in states that did not expand the program) and eligibility for federal subsidies for insurance purchased on the health insurance marketplaces, and affordability issues (Kaiser Family Foundation, 2015). The remaining uninsured population likely includes a disproportionally high number of the approximately 11 million undocumented immigrants in the U.S. (Passel and Cohn, 2009; Passel et al., 2014), who are less likely to be insured (Wallace et al., 2013; Artiga et al., 2016).

Although most agree that high health care spending is a major problem and access and quality of care should be improved, health care reform efforts are often constrained by political issues and the desire to maintain existing systems. Proposed changes to the health care system, and resistance to such changes, are often ideological and are labeled politically "right" or "left" often without an understanding of the substantive content. Some call for repeal and replacement of the ACA, while others argue to fix and repair the ACA. In addition to the coverage provisions of the ACA, numerous demonstration projects involving quality and cost initiatives are underway as policymakers, payers, practitioners, and researchers are still figuring out how to address adequately high health care costs while maintaining or improving quality. The ACA attempts to address many of the problems in the system, but how well its provisions work remains to be seen as the implementation of the ACA continues. The Congressional Budget Office (CBO) has estimated that the ACA provisions will save $\$ 137$ billion over 2016-2025 but 
also acknowledges that there substantial uncertainty in this estimate, enough that the estimate could be reversed and instead increase federal expenditures (Congressional Budget Office, 2015b).

\section{Background}

\section{Types of Health Care Systems}

Health care systems vary country by country but generally follow similar models. Reid classifies health care systems in four basic models: Beveridge, Bismarck, National Health Insurance, and Out-of-Pocket (Reid, 2009). Other classifications describe three main models that include National Health Insurance as a Beveridge model (Kulesher and Forrestal, 2014; Lameire, Joffe and Wiedemann, 1999). In the Beveridge model, health care is financed through taxes and is provided by the government as the single payer. An example of the Beveridge model is the United Kingdom's National Health Service, in which most hospitals are government facilities and health care providers are government employees. The National Health Insurance model also has the government as the single payer with financing from residents generally through taxes. However, one distinction from the National Health Service is that the National Health Insurance model relies on mostly private providers to deliver care. The health system in Canada is an example of the National Health Insurance model. The Bismarck model has employer-sponsored insurance and coverage provided through non-profit, private insurers. For example, Germany's sickness funds are compulsory (high-income individuals may opt out) and financed through payroll taxes (premium contributions for the unemployed are made by federal and local governments), and care is delivered through private providers. Last, the Out-of-Pocket model is a system in which most people pay for services directly without a widespread insurance system; this model exists mostly in developing countries. 
The U.S. health care system is unique in that it incorporates aspects of these four basic models for subsets of its population. The Veterans Health Administration follows the Beveridge model. Medicare follows a National Health Insurance model for those ages 65 and older or with a qualifying disability. The employer-sponsored insurance system for the majority of Americans is similar to the Bismarck model, although insurers are generally not non-profit. Finally, the health care system for the uninsured population operates as an Out-of-Pocket model. As the U.S. includes aspects of several types of health models, the result is a complicated system of multiple payers and financing structures.

\section{Single-Payer Systems}

The term "single payer" is used in different ways. The term originated as a descriptor of the Canadian national health insurance system, but is sometimes used more broadly to include Beveridge models (Tuohy, 2009). In addition, the term is sometimes used interchangeably with universal coverage (although different types of systems can achieve universal coverage) or used loosely to describe any European health care system. Understanding what is meant by a singlepayer system is important for policymakers who would design such a system, as well as the politics around single-payer systems. A Kaiser Family Foundation tracking poll found that the American public has different reactions to the following terms: Medicare-for-all, guaranteed universal health coverage, single-payer health insurance system, and socialized medicine (DiJulio et al., 2016). Each term has certain connotations and one indication of the ambiguity of the terms is the differential favorability ratings for a single-payer system ( $44 \%$ positive, $40 \%$ negative) and Medicare-for-all (63\% positive, $29 \%$ negative), which has been used to label different proposals but could be considered a subset of single-payer systems. 
In practice, single-payer health care systems vary by numerous characteristics, such as the payer structure and administration, financing mechanism, population covered, services covered, cost sharing, provider characteristics, provider payment mechanisms, and the role of private insurers. Table 1.1 contains examples of health care systems that may be referred to as singlepayer. The listing is intended to be inclusive; thus, the table includes systems that not all would consider single-payer.

Table 1.1. Examples of Health Care Systems with a Single Payer

\begin{tabular}{ll}
\hline Australia - Medicare & Norway - National Insurance Scheme \\
Canada - Medicare & Portugal - National Health Service \\
Denmark & South Korea - National Health Insurance \\
Finland & Spain - National Health System \\
Greece - National Health Service & Sweden \\
Iceland & Taiwan - National Health Insurance \\
Israel - National Health Insurance & United Kingdom - National Health Service \\
Italy - National Health Service & United States - Medicare \\
New Zealand & United States - Veterans Health Administration \\
\hline SOURCES: European Observatory on Health Systems and Policies 2014; Thomson et al. 2013; Lu and Chiang 2011
\end{tabular}

Countries with national single-payer systems typically provide universal coverage to legal residents. Subnational systems such as the U.S. Medicare and Veterans Health Administration systems cover all members of their defined population. Most, but not all, provide comprehensive benefits including hospital and physician services. Most countries allow complementary insurance for services not covered by the single-payer plan, and some allow supplementary insurance for parallel coverage (e.g., improved access or private rooms) and/or substitutive insurance for coverage that duplicates benefits provided by the single-payer plan.

In addition to providing health insurance coverage for all, proponents of single-payer systems claim that single-payer systems reduce costs through administrative efficiencies, increased purchasing power, and budgetary control (Woolhandler et al., 2003; General Accounting Office, 1991). Administrative costs may be lower due to reduced complexities in billing, claim 
processing, and marketing. A single-payer system that is centrally administered may be better able to control costs, such as through global budgeting and promoting cost-effective care. Opponents of single-payer systems point to the potential for long waiting times if the supply of health care services are constrained, diminished innovation, and other consequences of ineffective cost control strategies (Deber, 2003; Shaw, 2005; Thomson et al., 2013; Emanuel, 2008).

\section{Single-Payer Health Care Reform in the U.S.}

National health insurance through a single payer has been proposed as a way to achieve universal coverage in the U.S. since the early 1900s (Harrison, 2003; Kaiser Family Foundation, 2009; Morone, 2010). However, proposals have faced strong opposition from some stakeholder groups and have been stymied by political constraints. For example, President Franklin D. Roosevelt pulled his support from national health insurance in order to focus on passing the Social Security Act in 1935, partly due to powerful opposition by the American Medical Association (Blumenthal, 2006). After World War II, President Harry Truman included a provision on national health insurance administered through Social Security, but the effort again faced strong opposition and was labeled as socialized medicine. In recent debates, "single payer" is a politically charged term that is often used without a clear definition of its meaning. Most recently, Senator Bernie Sanders has highlighted his single-payer plan as part of his 2016 presidential campaign (Sanders, 2016).

While federal legislation has not gained significant traction, legislation for single-payer systems at the state level has also been proposed in numerous states. In 2011, Vermont became the first state to enact legislation for a single-payer system, with plans to implement the system in 2017 (Vt. Act 48, 2011). Observations of Vermont's single-payer experience may provide 
lessons to other states considering single-payer alternatives (Hsiao et al., 2011). Despite substantial planning and analysis that was undertaken to operationalize Vermont's single-payer aspirations, the state administration announced in December 2014 that it will not pursue legislation on the financing plan due to the considerable tax burden that would need to be placed on Vermont residents and businesses (The Official Website of the Governor of Vermont, 2014). In November 2016, Colorado residents will vote on a ballot measure (Amendment 69) that would establish ColoradoCare as a state-run health system (Hanel et al., 2016).

\section{Objectives}

Given the issues that remain post-ACA, health reform proposals and legislation for additional changes to improve the health care system have continued, and have included proposals for single-payer health care. Clearly defined proposals for improved health systems and evidence of their effects will inform the continued debate.

This dissertation explores single-payer health care alternatives through the following questions:

1. What is a single-payer system?

a) What are definitions of a single payer?

b) What are the proposed changes and aims in single-payer proposals?

2. What are the potential effects of single-payer scenarios on coverage and spending in the U.S.?

a) What is the effect of utilization changes on overall health care spending?

b) What are the distributional effects of financing plans on spending?

c) How much impact would allowing private insurance options alongside a single-payer plan have on coverage and spending?

d) What are the estimated spending effects of other savings and costs relating to administration and drug and provider prices?

e) How can uncertainties in the estimated effects be communicated? 
In Chapter 2, I discuss definitions of single-payer systems and the landscape of single-payer proposals. Chapter 3 contains estimates of health insurance coverage and health care spending under single-payer scenarios. I modeled two sets of national scenarios based on existing proposals: comprehensive scenarios with uniform coverage and catastrophic scenarios with income-dependent coverage. In Chapter 4, I describe an interactive cost tool that I developed to increase transparency of the savings and costs assumptions underlying the spending estimates. I present conclusions and policy implications in Chapter 5. 


\section{Single-Payer Definitions and Proposals in the U.S. Context}

In order to achieve the "Triple Aim" of improved care experience, improved population health, and reduced per capita health care costs (Berwick, Nolan and Whittington, 2008), further changes to the U.S. health care system are needed. Throughout the passage of the ACA and implementation that is still underway, the ACA has received constant scrutiny, drawing both praise and criticism. With the ACA coverage provisions, insurance coverage has increased by approximately 20 million people (Uberoi, Finegold and Gee, 2016), but a coverage gap of 27 million Americans is projected to remain in 2025 (Congressional Budget Office, 2015c). Similarly, demonstration projects under the Centers of Medicare and Medicaid Innovation (CMMI) are in progress, but their effectiveness in improving quality of care and reducing health care costs is not yet clear. As inadequacies in coverage, access, quality, and costs are likely to be not fully addressed by the ACA, debates on health care reform have continued. Policymakers have proposed alternative ways of improving the health care system, including fixing or repealing certain provisions of the ACA as well as introducing completely different models of health care financing and delivery.

One set of reform alternatives that has been considered at both the federal and state levels is a single-payer system. National health insurance administered by a single payer has been considered in the U.S. since the early 1900s (Harrison, 2003; Kaiser Family Foundation, 2009). A recent attempt to implement a state-based single-payer system by the state of Vermont (An act relating to a universal and unified health system, 2011) was halted at the end of 2014, with the governor's office citing higher than expected estimates of taxes needed to finance the system (State of Vermont Agency of Administration, 2014; McDonough, 2015). Although other bills 
have been proposed at the federal and state levels, none have garnered substantial legislative support. However, Senator Bernie Sanders' single-payer plan as part of his 2016 presidential campaign (Sanders, 2016) has brought renewed attention to single-payer proposals. Single-payer legislation faces political challenges in passage, operational challenges in implementation, and uncertain impacts on spending and health outcomes.

Although health care reform with a single payer has been continually proposed in the U.S., the term is often used with different meanings. Single-payer is often used in political rhetoric, with some using it to refer to the Canadian health care system, others using it synonymously with "social insurance," and other variations (Sparer, Brown and Jacobs, 2009). Canada has a singletiered, tax-financed system that is administered by the provinces and care is delivered by private, non-profit providers. Social insurance typically refers to systems such as the National Health Service in the United Kingdom, which is a tax-financed system with mostly government-run health facilities. Although the term single-payer is used loosely in political discourse, welldefined proposals for health care reform must delineate the scope and role of a single payer in health care financing and delivery.

In this chapter, I describe single-payer definitions and the contents of health care reform proposals that involve a single payer. I assessed the breadth of the proposal provisions across health care financing and delivery functions. To assess how the provisions aim to improve the health care system, I evaluated how they address health care access, quality, and costs. I also considered how the proposals compare to different definitions of single-payer systems. Clearly defined policy proposals would inform the debate on whether a single-payer system could be a viable and effective reform alternative in the U.S. 


\section{Background}

\section{Conceptual Framework of Health System Functions}

A health system typically has four major functions: revenue collection, pooling of funds, purchasing of services, and provision of services (Kutzin, 2001). Following the framework developed by Kutzin (2001), Figure 2.1 shows the process flow between these four functions of a health system and the interactions with individuals and regulation. The cones indicate the flow of funds. Revenue is collected in the form of contributions (e.g., taxes, premiums) from individuals to payers (e.g., private insurers, governments, self-insured employers). These funds are pooled on behalf of the eligible population and allocated to the purchasers of services, who pay providers in exchange for services for the covered individuals. Provision of services involves the delivery of care for covered benefits and may include cost sharing for individuals (e.g., copayments, deductibles). Health system reforms may involve changes to eligibility, financing, type and number of payers, payment system, delivery system, covered benefits, cost sharing, and regulation of each function.

Figure 2.1. Conceptual Framework of a Health System.

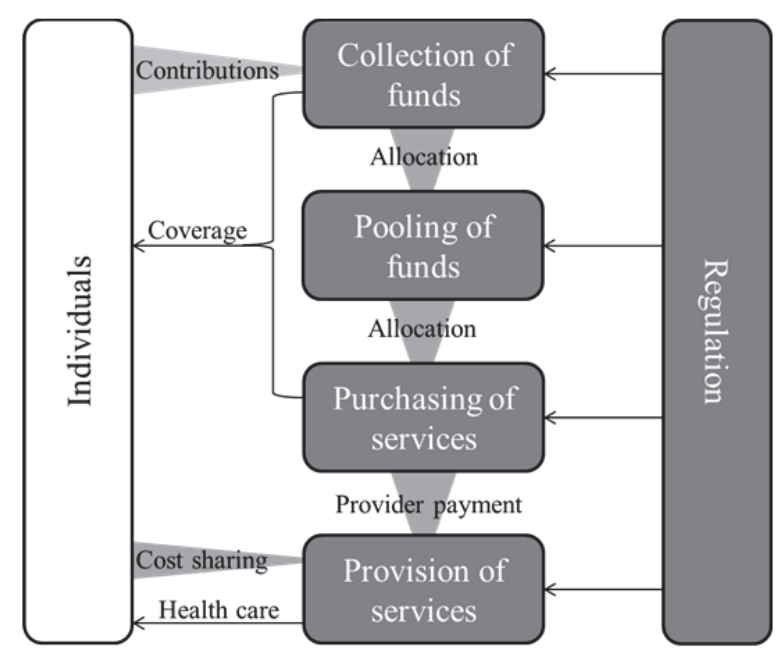

SOURCE: Adapted from Kutzin, 2001. 


\section{Methods}

\section{Literature Review}

I conducted literature searches on legislative and academic journal databases to identify proposals involving a single payer. I used the following search terms: single payer, Medicare for all, national health insurance, Beveridge model, universal coverage, publicly funded, United States, America, definition, proposal, plan, and bill. I excluded search results from earlier than 1990 because the term single-payer in its current usage appeared in the early 1990s and may have been used differently in prior years (Tuohy, 2009).

The initial search for federal and state single-payer bills on Congress.gov, Scout, and WestlawNext yielded 262 results. I reviewed titles and bill summaries to determine inclusion. Resolutions were excluded. If a group or legislative body had produced multiple proposals, only the most recent version was included. I identified additional state legislation via Google searches and reference mining. These searchers resulted in the identification of three federal bills and 20 state bills that proposed single-payer systems.

Literature searches on PubMed, Scopus, and Academic Search Complete resulted in 2,498 articles. Articles discussing only existing proposals, politics, stakeholder perspectives, implementation, and health care reform in other countries were excluded. Screening of the titles and abstracts resulted in 29 articles. A full text review of the articles resulted in two unique proposals that were not legislative bills.

\section{Assessment of Proposals}

Using the proposals identified in the literature review, I assessed the proposals in terms of their breadth across health care system functions and their relation to access, quality, and cost.

I assessed the breadth of the proposals based on the inclusion of provisions relating to the health care system functions shown in Figure 2.1. This conceptual framework, adapted from 
Kutzin (2001), shows four main functions of a health care system: the collection of funds, pooling of funds, purchasing of services, and provision of services. These functions include financing functions of a health care system as well as health care delivery functions. The collection of funds includes the types of revenue sources and the levels of contribution. Funds are pooled for the eligible population. Purchasing of services includes provider payment schemes, such as fee-for-service and institutional budgets. The provision of services includes specifications of the covered services and the eligibility of participating providers. The characteristics of single-payer proposals relating to these health care system functions were placed into a matrix to enable comparison across the proposed single-payer systems.

To evaluate how the provisions of the proposals would improve the health care system, I considered linkages to increased health care access, better quality of care, and cost containment. As the impacts of the provisions have not been scored, I coded the intent and plausible impact of measures aiming to improve access, quality, and cost containment based on the proposal text. When the assignment of access, quality, and cost was unclear, a second reviewer (RB) independently assessed the assignment and then the reviewers discussed and reconciled the assignment. I documented the measures into a matrix and tallied the results in order to identify common themes relating to access, quality, and cost.

\section{Results}

\section{Definitions of Single-Payer Systems}

Tuohy (2009) describes the origination of the term single-payer as a descriptor of the Canadian health care system, in which medical and hospital services are financed by the government and delivered by private providers. The term was meant to differentiate the system in Canada from that in the United Kingdom, where the government is responsible for both 
financing and delivery. However, the term has since evolved to often be used as a descriptor of financing by a single public entity, irrespective of the delivery of care. Merriam-Webster dictionary defines single-payer as "of, relating to, or being a system in which health-care providers are paid for their services by the government rather than by private insurers." Table 2.1 shows a summary of single-payer definitions. The definitions are listed from narrow to broad. Most definitions include a description of the payer, most frequently described as a government, though some allow for the possibility of a private entity as the payer. Half the definitions explicitly describe the eligible population (frequently as universal or the entire population), characteristics of the plan and benefits (e.g., comprehensive, limited cost sharing, uniform benefits), and financing (e.g., government funds, tax revenue). The geographic area of coverage was also mentioned in several definitions. Characteristics that were mentioned in only a few of the definitions were provider characteristics (e.g., private, non-profit), provider payment mechanisms, simplified administration, cost controls, and the role of private insurance.

Although the single payer is most frequently thought of as a public entity, some definitions do not restrict the payer to only government. For example, Slee and Slee (1994) describe a single-payer system as a "method of health care financing in which there is only one source of money for paying health care providers.... the single-payer could be an insurance company. Or the scope of the plan would not have to be national; it could be employed by a single state or community." The Slee and Slee definition also expands the geographic level to subnational systems, which better describes the Canadian system that is decentralized to 13 local payers one for each province and territory. Similarly, Kutzin (2001) describes a single payer with flexible geography and public/private sector affiliation, as a "single purchaser for the main service package on behalf of the entire population living in a defined geographic area," while also specifying a minimum level for the benefit package. 


\begin{tabular}{|c|c|c|c|c|c|c|c|c|c|c|}
\hline Source & Definition & & & & & & & & & \\
\hline $\begin{array}{l}\text { Medicine } \\
\text { Net, } \\
2012\end{array}$ & $\begin{array}{l}\text { "A system of health care characterized by universal and } \\
\text { comprehensive coverage. Single-payer health care is similar to the } \\
\text { health services provided by Medicare in the US. The government } \\
\text { pays for care that is delivered in the private (mostly not-for-profit) } \\
\text { sector. Doctors are in private practice and are paid on a fee-for- } \\
\text { service basis from government funds....Single-payer health care is } \\
\text { distinct and different from socialized medicine in which health care } \\
\text { facilities and workers receive payment as government employees." }\end{array}$ & $\checkmark$ & $\checkmark$ & $\checkmark$ & $\checkmark$ & & \begin{tabular}{l|l}
$\checkmark$ & $\checkmark$
\end{tabular} & & & \\
\hline $\begin{array}{l}\text { Blewett, } \\
2009\end{array}$ & $\begin{array}{l}\text { "a government-run health care system, providing universal benefits } \\
\text { to all, financed by general tax revenue" and can have "simplified } \\
\text { administration, uniform benefits, and explicit controls on costs" }\end{array}$ & $\checkmark$ & $\checkmark$ & $\checkmark$ & $\checkmark$ & & & $\checkmark$ & $\checkmark$ & \\
\hline $\begin{array}{l}\text { White, } \\
2009\end{array}$ & $\begin{array}{l}\text { a system in which a government organization is the primary payer } \\
\text { for all citizens "in any given geographic area", who make } \\
\text { "mandatory contributions to a single pool" and receive coverage of } \\
\text { "normal medical and hospital care" }\end{array}$ & $\checkmark$ & $\checkmark$ & $\checkmark$ & $\checkmark$ & $\checkmark$ & & & & \\
\hline $\begin{array}{l}\text { Tuohy, } \\
2009\end{array}$ & $\begin{array}{l}\text { a government plan that does not "compete(s) with other insurers in } \\
\text { offering comprehensive coverage.....could be contained in a broader } \\
\text { hybrid, by restricting the scope...by the population group... by the } \\
\text { category of service...by jurisdiction" }\end{array}$ & $\checkmark$ & $\checkmark$ & $\checkmark$ & & $\checkmark$ & & & & \\
\hline $\begin{array}{l}\text { Kutzin, } \\
2011\end{array}$ & $\begin{array}{l}\text { "a single purchaser for the main service package on behalf of the } \\
\text { entire population living in a defined geographic area" }\end{array}$ & $\checkmark$ & $\checkmark$ & $\checkmark$ & & $\checkmark$ & & & & \\
\hline $\begin{array}{l}\text { Glied, } \\
2009\end{array}$ & $\begin{array}{l}\text { single-payer advocates call for "a universal, single-tiered, public } \\
\text { insurance system, with limited or no patient cost sharing, that pays } \\
\text { for the services of private, not-for-profit providers" }\end{array}$ & $\checkmark$ & $\checkmark$ & $\checkmark$ & & & $\checkmark$ & & & \\
\hline $\begin{array}{l}\text { Slee and } \\
\text { Slee, } \\
1994\end{array}$ & $\begin{array}{l}\text { "A method of health care financing in which there is only one source } \\
\text { of money for paying health care providers. The Canadian-style } \\
\text { system is the prime example of a single-payer plan, but not all } \\
\text { elements of the Canadian program need to be included for a plan to } \\
\text { be "single-payer"; in fact, the single-payer could be an insurance } \\
\text { company. Or the scope of the plan would not have to be national; it } \\
\text { could be employed by a single state or community. Proponents of a } \\
\text { single-payer plan emphasize the administrative simplicity for } \\
\text { patients and providers, and the resulting significant savings in cost." }\end{array}$ & $\checkmark$ & & & $\checkmark$ & $\checkmark$ & & $\checkmark$ & & \\
\hline $\begin{array}{l}\text { Tuohy, } \\
2009\end{array}$ & $\begin{array}{l}\text { originally used to describe a system "which health care is financed } \\
\text { by government and delivered by privately owned and operated } \\
\text { health care providers" }\end{array}$ & $\checkmark$ & & & $\checkmark$ & & $\checkmark$ & & & \\
\hline $\begin{array}{l}\text { Oliver, } \\
2009\end{array}$ & $\begin{array}{l}\text { a single collector with the possibility of multiple payers at the local } \\
\text { level }\end{array}$ & $\checkmark$ & & & & $\nabla$ & & & & \\
\hline $\begin{array}{l}\text { Glied, } \\
2009\end{array}$ & $\begin{array}{l}\text { a system that relies on "a limited number of revenue sources and } \\
\text { systems in which financing is concentrated and private insurance } \\
\text { for hospital and medical services is limited"; single-payerness: } \\
\text { characterized by the number of revenue sources, use of private } \\
\text { insurance, and subnational financing }\end{array}$ & & & & $\checkmark$ & & & & & \\
\hline $\begin{array}{l}\text { Merriam- } \\
\text { Webster }\end{array}$ & $\begin{array}{l}\text { "of, relating to, or being a system in which health-care providers are } \\
\text { paid for their services by the government rather than by private } \\
\text { insurers" }\end{array}$ & $\checkmark$ & & & & & & & & \\
\hline $\begin{array}{l}\text { Stone, } \\
2009\end{array}$ & a rhetorical term used in politics to avoid the term "social insurance" & & & & & & & & & \\
\hline
\end{tabular}


In a 2009 special issue of the Journal of Health Politics, Policy and Law on single-payer concepts, several authors note the lack of consensus on what is meant by single-payer and offer definitions of single-payer systems (Sparer, Brown and Jacobs, 2009). The definitions proposed by Oliver, Tuohy, and White allow for single-payer systems within broader systems, by restricting the scope of the single payer by different characteristics. Oliver (2009) describes a single payer as a single collector with the possibility of multiple payers at the local level. Tuohy (2009) suggests using the population covered, service category, and jurisdiction to describe a single-payer system within a broader hybrid. White (2009) further restricts the scope of singlepayer as a system for all citizens in a geographic area, who make "mandatory contributions to a single pool" and receive coverage of "normal medical and hospital care." Although the above definitions focused on the financing source, eligible population, and service package, Blewett (2009) also includes the possibility of "simplified administration" and "explicit controls on costs" as part of a definition. Glied (2009) refers to single-payer advocates who call for little or no cost sharing and the delivery of care by private, non-for-profit providers. In addition, Glied offers a definition that departs from defining single-payer to describing "single-payerness" based on the number of revenue sources, use of private insurance, and subnational financing. Last, Stone (2009) calls single payer a rhetorical term used in politics to avoid naming anything "social insurance."

\section{Role of Private Insurance alongside a Single Payer}

Private insurance options may be available alongside a statutory public plan. Mossialos and Thomson (2004) describe three roles of private voluntary health insurance in this capacity: complementary, supplementary, and substitutive. Complementary insurance covers services that are excluded or not fully covered in the statutory plan, e.g., prescriptions or dental coverage could be acquired through private insurance if it is not included in statutory benefits, or 
copayments could be reduced. ${ }^{2}$ White (2009) refers to complementary insurance as gap coverage that largely occurs when the statutory benefit package is inadequate. Supplementary insurance provides improved coverage; for example, faster access to a specialist or a provider for elective services, or increased choice of providers through private insurance. The existence of supplementary insurance in parallel to the statutory system may be partially due to capacity and access issues, e.g., long waiting times for services (White, 2009). Last, substitutive insurance, which duplicates coverage offered in the statutory plan, could be available to populations not covered by or those who opt out of the statutory plan.

\section{Single-Payer Proposals}

The 25 proposals reviewed in this analysis are shown in Table 2.2. Two proposals for a national program were identified from the literature (Woolhandler et al., 2003; Hagopian and Goldman, 2012). Three federal bills aiming to establish a single payer at the national level have been proposed in recent years: the Expanded \& Improved Medicare For All Act, the American Health Security Act, and the National Health Insurance Act (Expanded \& Improved Medicare For All Act, 2015; American Health Security Act of 2015, 2015; American Health Security Act of 2013, 2013; National Health Insurance Act, 2009). In this chapter, these journal articles, bills, and Vermont's Act 48 (originally a house bill that was enacted in 2011) will be collectively referred to as single-payer proposals.

The Physicians for a National Health Program (PNHP) proposal (Woolhandler et al., 2003) and the Health-Insurance Solution (Hagopian and Goldman, 2012) are two very different approaches to provide benefits for defined populations. The PNHP proposal recommends universal comprehensive coverage without copayments and deductibles. Duplication of the

\footnotetext{
${ }^{2}$ In the U.S., an example of complementary insurance is Medicare supplemental insurance, such as Medigap. Medigap is provided by private insurers and usually reduces cost sharing. Terminology for voluntary health insurance is not standardized; in addition, plans may be a combination of types.
} 
covered services by private insurance is prohibited. The proposal also includes provider payment reform, along with the conversion of investor-owned hospitals and other provider groups to notfor-profit status. Although a single payer is frequently the government, the Health-Insurance Solution would have a private insurer contracted by the federal government. Like the PNHP plan, the Health-Insurance Solution would be financed through taxes. However, instead of comprehensive benefits, the Health-Insurance Solution would provide catastrophic coverage with an income-dependent deductible and out-of-pocket maximum. Private insurance options alongside the catastrophic plan would not be restricted as some individuals may desire additional coverage to the catastrophic plan with high deductibles. For the purposes of the proposal, the coverage would apply to legal residents not covered under Medicare or Medicaid. Another key feature of the proposal is that tax subsidies for employer contributions to health insurance and for the self-employed would be eliminated.

Three federal bills aiming to establish a single payer at the national level have been proposed in recent years: the Expanded \& Improved Medicare For All Act (H.R. 676, 2013), the American Health Security Act (S. 1782, 2013; H.R. 1200, 2015), and the National Health Insurance Act (H.R. 15, 2009). These bills have had a long history of versions introduced and re-introduced in Congressional sessions as early as 1957. The Medicare For All Act and the American Health Security Act are similar. Both health plans would be financed through a combination of taxes, include provider payment reform, be comprehensive and cover all medically necessary services (including prescriptions and long-term care) without any cost sharing, and prohibit substitutive insurance. Other public programs such as Medicare, Medicaid, and CHIP would be transferred to the new plan. One notable difference is that the Medicare For All Act would require all health care providers to be public or not-for-profit. The Medicare For All Act also allows complementary insurance (not explicitly mentioned in the American Health Security Act). The 
single payer in the Medicare For All Act would be the federal government (with regional or state administration), while the single payer in the American Health Security Act would be state governments or groups of states. The National Health Insurance Act of 2009 similarly allows states to lead the administration of benefits, with the option of local administration. A global budget would be set each year, and administrative costs could not to exceed five percent of aggregate expenditures. The Secretary of Department of Health and Human Services would conduct studies of cost control mechanisms and how Medicare may be transferred into the program under this act. 
Table 2.2. Characteristics of Single-Payer Proposals

\begin{tabular}{|c|c|c|c|c|c|}
\hline Proposal/Bill & Author, Year & Payer & Eligibility & Coverage & Financing \\
\hline $\begin{array}{l}\text { Proposal of the } \\
\text { Physicians' } \\
\text { Working Group } \\
\text { for Single-Payer } \\
\text { National Health } \\
\text { Insurance }\end{array}$ & $\begin{array}{l}\text { Woolhandler, } \\
\text { Himmelstein, } \\
\text { et.al., } 2003\end{array}$ & $\begin{array}{l}\text { Federal } \\
\text { government as } \\
\text { the single } \\
\text { insurer; regional } \\
\text { offices and } \\
\text { boards to aid in } \\
\text { administration }\end{array}$ & All Americans & $\begin{array}{l}\text { Comprehensive: all medically } \\
\text { necessary services, including } \\
\text { prescriptions, mental health, dental, } \\
\text { and long-term care } \\
\text { No cost sharing }\end{array}$ & $\begin{array}{l}\text { Combination of taxes, e.g., income, } \\
\text { payroll }\end{array}$ \\
\hline $\begin{array}{l}\text { Health- } \\
\text { Insurance } \\
\text { Solution }\end{array}$ & $\begin{array}{l}\text { Hagopian and } \\
\text { Goldman, } 2012\end{array}$ & $\begin{array}{l}\text { A private insurer } \\
\text { contracted by } \\
\text { the federal } \\
\text { government as } \\
\text { the single } \\
\text { insurer }\end{array}$ & $\begin{array}{l}\text { All legal } \\
\text { residents not } \\
\text { covered by } \\
\text { Medicare or } \\
\text { Medicaid }\end{array}$ & $\begin{array}{l}\text { Catastrophic: income-dependent } \\
\text { coverage for health care costs } \\
\text { Deductible set at } 10 \% \text { of adjusted } \\
\text { gross income beyond Medicaid } \\
\text { thresholds, } 5 \% \text { copayment between } \\
\text { the deductible, and the out-of-pocket } \\
\text { maximum set at } 10 \text { times the } \\
\text { deductible }\end{array}$ & $\begin{array}{l}\text { Per-capita tax (“Catastrophic Insurance } \\
\text { Premium”) set at approximately the } \\
\text { actuarial value of the benefits; } \\
\text { subsidies for individuals }<300 \% \text { FPL }\end{array}$ \\
\hline $\begin{array}{l}\text { Expanded \& } \\
\text { Improved } \\
\text { Medicare For All } \\
\text { Act (HR 676, } \\
\text { 113th Congress) }\end{array}$ & $\begin{array}{l}\text { Representative } \\
\text { John Conyers, } \\
\text { Jr. (D-MI), } 2013\end{array}$ & $\begin{array}{l}\text { Federal } \\
\text { government as } \\
\text { the single } \\
\text { insurer; regional } \\
\text { and state } \\
\text { administration }\end{array}$ & $\begin{array}{l}\text { All U.S. } \\
\text { residents }\end{array}$ & $\begin{array}{l}\text { Comprehensive: all medically } \\
\text { necessary services, including primary } \\
\text { care, prescriptions, mental health, } \\
\text { dental, vision, palliative care and long- } \\
\text { term care } \\
\text { No cost sharing }\end{array}$ & $\begin{array}{l}\text { Federal government revenue (including } \\
\text { Medicare, Medicaid, CHIP } \\
\text { appropriations), personal income tax, } \\
\text { excise tax on payroll and self- } \\
\text { employment income, tax on unearned } \\
\text { income, tax on stock and bond } \\
\text { transactions } \\
\text { Funds to be deposited in the Medicare } \\
\text { for All Trust Fund, which will be used } \\
\text { for health care expenditures }\end{array}$ \\
\hline $\begin{array}{l}\text { American Health } \\
\text { Security Act (S } \\
\text { 1782, 113th } \\
\text { Congress; HR } \\
\text { 1200, 114th } \\
\text { Congress) }\end{array}$ & $\begin{array}{l}\text { Senator Bernard } \\
\text { Sanders (I-VT), } \\
2013, \\
\text { Representative } \\
\text { Jim McDermott } \\
\text { (D-WA), } 2015\end{array}$ & $\begin{array}{l}\text { State } \\
\text { governments or } \\
\text { a group of } \\
\text { neighboring } \\
\text { states as the } \\
\text { single insurers } \\
\text { for states or } \\
\text { regions }\end{array}$ & $\begin{array}{l}\text { All U.S. } \\
\text { residents }\end{array}$ & $\begin{array}{l}\text { Comprehensive: all medically } \\
\text { necessary services, including } \\
\text { community-based primary care, } \\
\text { prescriptions, dental, and long-term } \\
\text { care } \\
\text { No cost sharing }\end{array}$ & $\begin{array}{l}\text { Income tax, excise tax on securities } \\
\text { transactions, payroll tax on employers, } \\
\text { self-employment tax } \\
\text { Funds to be deposited in the American } \\
\text { Health Security Trust Fund, from which } \\
\text { funds will be allocated to states }\end{array}$ \\
\hline
\end{tabular}




\begin{tabular}{|c|c|c|c|c|c|}
\hline Proposal/Bill & Author, Year & Payer & Eligibility & Coverage & Financing \\
\hline $\begin{array}{l}\text { National Health } \\
\text { Insurance Act } \\
\text { (HR 15, 111th } \\
\text { Congress) }\end{array}$ & $\begin{array}{l}\text { Representative } \\
\text { John Dingell, Jr. } \\
\text { (D-MI), } 2009\end{array}$ & $\begin{array}{l}\text { Local areas or } \\
\text { states as the } \\
\text { single insurers } \\
\text { for the health- } \\
\text { service area }\end{array}$ & $\begin{array}{l}\text { All individuals, } \\
\text { and their } \\
\text { dependents, } \\
\text { meeting wage } \\
\text { thresholds or } \\
\text { receiving } \\
\text { disability or civil } \\
\text { service } \\
\text { retirement } \\
\text { benefits }\end{array}$ & $\begin{array}{l}\text { Comprehensive: all services essential } \\
\text { to good care, including medical, dental, } \\
\text { podiatric, home nursing, hospital, and } \\
\text { auxiliary services } \\
\text { Cost sharing allowed for additional } \\
\text { services not covered or more } \\
\text { expensive facilities } \\
\text { Benefits may be provided to ineligible } \\
\text { individuals if the Trust Fund is } \\
\text { reimbursed on behalf of the needy }\end{array}$ & $\begin{array}{l}\text { Value-added tax on sellers for the sale } \\
\text { of property, performance of services, } \\
\text { and import of property in commercial- } \\
\text { type transactions } \\
\text { Funds to be deposited in the National } \\
\text { Health Care Trust Fund, from which } \\
\text { funds will be allocated to states }\end{array}$ \\
\hline $\begin{array}{l}\text { An act to } \\
\text { establish a } \\
\text { single-payor } \\
\text { health care } \\
\text { system to be } \\
\text { effective in 2017 } \\
\text { (Maine, HP 962) }\end{array}$ & $\begin{array}{l}\text { State } \\
\text { Representative } \\
\text { Charles Priest } \\
\text { (D-Brunswick), } \\
2013\end{array}$ & $\begin{array}{l}\text { State } \\
\text { government as } \\
\text { the single } \\
\text { insurer, with } \\
\text { administration by } \\
\text { the Maine Health } \\
\text { Care Agency; } \\
\text { claims to be } \\
\text { administered by } \\
\text { a third-party } \\
\text { contractor }\end{array}$ & $\begin{array}{l}\text { All residents of } \\
\text { Maine } \\
\text { Non-residents } \\
\text { who maintain } \\
\text { "significant } \\
\text { contact with the } \\
\text { State", e.g., } \\
\text { employment or } \\
\text { higher education } \\
\text { in the state, to } \\
\text { be determined } \\
\text { by the Maine } \\
\text { Health Care } \\
\text { Agency }\end{array}$ & $\begin{array}{l}\text { Comprehensive: hospital, medical, } \\
\text { laboratory, imaging, home health, } \\
\text { rehabilitative, mental health, substance } \\
\text { abuse, dental, and hospice services; } \\
\text { prescription drugs; medical supplies } \\
\text { and equipment; vision appliances } \\
\text { The plan is the secondary payer to } \\
\text { other programs such as Medicare, } \\
\text { Medicaid, TRICARE, Indian Health } \\
\text { services, state and local health } \\
\text { programs (including workers' } \\
\text { compensation and employers' liability } \\
\text { insurance), and other third-party payers }\end{array}$ & $\begin{array}{l}\text { State appropriations, federal funds (as } \\
\text { allowed by waivers), grants, } \\
\text { contributions, taxes, and other revenue } \\
\text { Revenue to be deposited into the } \\
\text { Maine Health Care Trust Fund, which } \\
\text { will be used for health care services } \\
\text { and operation of the plan } \\
\text { Two financing plans to be proposed by } \\
\text { the Maine Health Care Agency, which } \\
\text { may include income, payroll, } \\
\text { consumption, and other taxes; and } \\
\text { provider and employer assessments }\end{array}$ \\
\hline $\begin{array}{l}\text { An act relating to } \\
\text { a universal and } \\
\text { unified health } \\
\text { system } \\
\text { (Vermont, H } \\
\text { 202, Act 48) }\end{array}$ & $\begin{array}{l}\text { State } \\
\text { Representative } \\
\text { Mark Larson (D- } \\
\text { Burlington), } \\
2011\end{array}$ & $\begin{array}{l}\text { State } \\
\text { government as } \\
\text { the single } \\
\text { insurer, with } \\
\text { administration by } \\
\text { the agency of } \\
\text { administration }\end{array}$ & $\begin{array}{l}\text { All residents of } \\
\text { Vermont }\end{array}$ & $\begin{array}{l}\text { Comprehensive: benefit package must } \\
\text { have at least } 80 \% \text { actuarial value; } \\
\text { specific services to be determined } \\
\text { Cost sharing to be determined }\end{array}$ & $\begin{array}{l}\text { Taxes to be determined, e.g., income, } \\
\text { payroll, consumption, other }\end{array}$ \\
\hline
\end{tabular}




\begin{tabular}{|c|c|c|c|c|c|}
\hline Proposal/Bill & Author, Year & Payer & Eligibility & Coverage & Financing \\
\hline $\begin{array}{l}\text { An act } \\
\text { establishing } \\
\text { Medicare for all } \\
\text { in } \\
\text { Massachusetts } \\
\text { (Massachusetts, } \\
\text { S 515) }\end{array}$ & $\begin{array}{l}\text { State Senator } \\
\text { James Eldridge } \\
\text { (D-Middlesex } \\
\text { and } \\
\text { Worchester), } \\
2013\end{array}$ & $\begin{array}{l}\text { State } \\
\text { government as } \\
\text { the single } \\
\text { insurer, with } \\
\text { administration } \\
\text { through a public } \\
\text { agency (the } \\
\text { Massachusetts } \\
\text { Health Care } \\
\text { Trust) and its } \\
\text { regional offices }\end{array}$ & $\begin{array}{l}\text { All } \\
\text { Massachusetts } \\
\text { residents, } \\
\text { including } \\
\text { homeless } \\
\text { persons, and } \\
\text { non-residents } \\
\text { who work at } \\
\text { least } 20 \text { hours } \\
\text { per week in MA, } \\
\text { pay MA income } \\
\text { and payroll } \\
\text { taxes, and pay } \\
\text { premiums are } \\
\text { eligible to enroll } \\
\text { in the system }\end{array}$ & $\begin{array}{l}\text { Comprehensive: including prevention, } \\
\text { diagnosis, and treatment; screening } \\
\text { and counseling; rehabilitation; } \\
\text { maternity and reproductive care; home } \\
\text { health care; long-term care; hospice } \\
\text { care; language interpretation; } \\
\text { emergency services; dental services; } \\
\text { vision and hearing services; } \\
\text { prescriptions; medical equipment and } \\
\text { supplies } \\
\text { Emergency care to be provided to non- } \\
\text { residents }\end{array}$ & $\begin{array}{l}\text { General fund transfers as needed ; } \\
\text { dedicated taxes: } 7.5 \% \text { employer payroll } \\
\text { tax (first } \$ 30 \mathrm{k} \text { exempt; }+0.44 \% \text { for } \\
\text { employers with } 100+\text { employees); } 2.5 \% \\
\text { employee payroll tax; } 10 \% \text { self- } \\
\text { employed payroll tax, } 10 \% \text { (first } \$ 30 \mathrm{k} \\
\text { exempt); } 10 \% \text { unearned income tax } \\
\text { Funds to be deposited in the } \\
\text { Massachusetts Health Care Trust }\end{array}$ \\
\hline $\begin{array}{l}\text { An act } \\
\text { concerning a } \\
\text { single-payer } \\
\text { health care } \\
\text { system } \\
\text { (Connecticut, SB } \\
60 \text { ) }\end{array}$ & $\begin{array}{l}\text { State Senator } \\
\text { Joseph J. Crisco } \\
\text { (D-Woodbridge), } \\
2013\end{array}$ & $\mathrm{n} / \mathrm{a}$ & $\mathrm{n} / \mathrm{a}$ & $\mathrm{n} / \mathrm{a}$ & $\mathrm{n} / \mathrm{a}$ \\
\hline $\begin{array}{l}\text { An act to amend } \\
\text { the public health } \\
\text { law and the state } \\
\text { finance law, in } \\
\text { relation to } \\
\text { establishing New } \\
\text { York Health } \\
\text { (New York, AB } \\
\text { 5389A) }\end{array}$ & $\begin{array}{l}\text { State Assembly } \\
\text { Member Richard } \\
\text { Gottfried (D- } \\
\text { Manhattan), } \\
2013\end{array}$ & $\begin{array}{l}\text { State } \\
\text { government as } \\
\text { the single } \\
\text { insurer, with } \\
\text { administration by } \\
\text { the New York } \\
\text { Health program }\end{array}$ & $\begin{array}{l}\text { All residents of } \\
\text { New York }\end{array}$ & $\begin{array}{l}\text { Comprehensive: all services that would } \\
\text { have otherwise been covered by } \\
\text { Family Health Plus, Child Health Plus, } \\
\text { Medicaid, and Medicare, and other } \\
\text { services added by the program }\end{array}$ & $\begin{array}{l}\text { Progressive payroll and self- } \\
\text { employment income taxes; progressive } \\
\text { tax on taxable income not covered in } \\
\text { payroll (e.g., interest, dividends, capital } \\
\text { gains); federal, state, and local funds } \\
\text { Revenues and payments made to and } \\
\text { from the New York Health Trust Fund }\end{array}$ \\
\hline $\begin{array}{l}\text { Family and } \\
\text { Business } \\
\text { Healthcare } \\
\text { Security Act } \\
\text { (Pennsylvania, } \\
\text { SB 400) }\end{array}$ & $\begin{array}{l}\text { State Senator } \\
\text { Jim Ferlo (D- } \\
\text { Lawrenceville), } \\
2013\end{array}$ & $\begin{array}{l}\text { State } \\
\text { government as } \\
\text { the single } \\
\text { insurer, with } \\
\text { administration } \\
\text { directly from an } \\
\text { established } \\
\text { health agency or } \\
\text { through one or } \\
\text { more contractors }\end{array}$ & $\begin{array}{l}\text { All residents of } \\
\text { Pennsylvania, } \\
\text { including aliens, } \\
\text { lawful } \\
\text { immigrants, } \\
\text { homeless } \\
\text { persons, and } \\
\text { migrant workers } \\
\text { and families }\end{array}$ & $\begin{array}{l}\text { Comprehensive: all medically } \\
\text { necessary services, including hospital, } \\
\text { medical, mental health, substance } \\
\text { abuse treatment, hospice, prescription } \\
\text { drugs, vision, hearing, dental, and long- } \\
\text { term care }\end{array}$ & $\begin{array}{l}\text { Federal health care program funds, } \\
\text { state appropriations, } 10 \% \text { tax on gross } \\
\text { payroll, } 3 \% \text { individual income tax } \\
\text { Funds to be deposited in the } \\
\text { Pennsylvania Health Care Trust Fund }\end{array}$ \\
\hline
\end{tabular}




\begin{tabular}{|c|c|c|c|c|c|}
\hline Proposal/Bill & Author, Year & Payer & Eligibility & Coverage & Financing \\
\hline $\begin{array}{l}\text { Maryland Health } \\
\text { Benefit } \\
\text { Exchange - } \\
\text { Universal Health } \\
\text { Care Program - } \\
\text { Plan for } \\
\text { Establishment } \\
\text { (Maryland, S } \\
667 \text { ) }\end{array}$ & $\begin{array}{l}\text { State Senator } \\
\text { Paul Pinsky (D- } \\
\text { Prince George's } \\
\text { County), } 2014\end{array}$ & $\begin{array}{l}\text { State } \\
\text { government as } \\
\text { the single } \\
\text { insurer }\end{array}$ & $\begin{array}{l}\text { All residents of } \\
\text { Maryland }\end{array}$ & $\begin{array}{l}\text { Comprehensive: including preventive } \\
\text { care, primary care, chronic care, acute } \\
\text { care, and hospital services }\end{array}$ & $\begin{array}{l}\text { To be determined based on cost } \\
\text { projections and recommendations by } \\
\text { the Board of Trustees of the Maryland } \\
\text { Health Benefit Exchange }\end{array}$ \\
\hline $\begin{array}{l}\text { Delaware Health } \\
\text { Security Act } \\
\text { (Delaware, HB } \\
\text { 74) }\end{array}$ & $\begin{array}{l}\text { State } \\
\text { Representative } \\
\text { John Kowalko } \\
\text { (D-Newark } \\
\text { South), } 2013\end{array}$ & $\begin{array}{l}\text { State } \\
\text { government as } \\
\text { the single } \\
\text { insurer, with } \\
\text { administration by } \\
\text { the Delaware } \\
\text { Health Security } \\
\text { Authority }\end{array}$ & $\begin{array}{l}\text { All citizens of } \\
\text { Delaware } \\
\text { Non-residents } \\
\text { who work } \geq 20 \\
\text { hours per week } \\
\text { in state } \\
\text { (including legal } \\
\text { aliens), pay state } \\
\text { income and } \\
\text { payroll taxes, } \\
\text { and pay } \\
\text { applicable } \\
\text { premiums for at } \\
\text { least } 90 \text { days }\end{array}$ & $\begin{array}{l}\text { Comprehensive: all necessary or } \\
\text { appropriate care, including preventive } \\
\text { services, diagnostics, emergency care, } \\
\text { mental health care, dental care, } \\
\text { acupuncture, vision care, chiropractic } \\
\text { services, pediatric care, rehabilitation } \\
\text { services, prescription drugs, screening, } \\
\text { counseling, health education, home } \\
\text { health care, hospice care, maternity } \\
\text { care, family planning, and reproductive } \\
\text { care } \\
\text { Emergency care to be provided to all } \\
\text { individuals }\end{array}$ & $\begin{array}{l}\text { State appropriations, federal funds (if } \\
\text { waivers obtained), employer payroll } \\
\text { tax, income tax, gifts, and rebates } \\
\text { Employer payroll tax: } 4 \% \text { for employers } \\
\text { with }<10 \text { employees, } 5 \% \text { for } 10-24,7 \% \\
\text { for } 25-49 \text {, and } 9 \% \text { for } \geq 50 \text {; } \\
\text { Personal income tax: } 2.5 \% \text {; an extra } \\
2.5 \% \text { on taxable income }>\$ 250,000 \text { if } \\
\text { single and }>\$ 500,000 \text { if married } \\
\text { Funds to be deposited to the Delaware } \\
\text { Health Security Authority Fund, which } \\
\text { will be used for provider payments, } \\
\text { preventive services, outreach and } \\
\text { education, and administrative costs }\end{array}$ \\
\hline $\begin{array}{l}\text { An act to provide } \\
\text { for the North } \\
\text { Carolina Health } \\
\text { Plan to cover all } \\
\text { state residents } \\
\text { with } \\
\text { comprehensive } \\
\text { health benefit } \\
\text { coverage... } \\
\text { (North Carolina, } \\
\text { HB 70) }\end{array}$ & $\begin{array}{l}\text { State } \\
\text { Representative } \\
\text { Marcus Brandon } \\
\text { (D-Greensboro), } \\
2013\end{array}$ & $\begin{array}{l}\text { State } \\
\text { government as } \\
\text { the single } \\
\text { insurer, with } \\
\text { executive } \\
\text { governance and } \\
\text { a governing or } \\
\text { advisory board } \\
\text { TBD }\end{array}$ & $\begin{array}{l}\text { All residents of } \\
\text { North Carolina }\end{array}$ & $\begin{array}{l}\text { Comprehensive: including health care } \\
\text { services at facilities, offices, and clinics; } \\
\text { preventive health care; medical and } \\
\text { surgical supplies; durable medical } \\
\text { equipment; prescription drug formulary; } \\
\text { long-term care and personal } \\
\text { assistance; hospice care, mental health } \\
\text { treatment; dental services }\end{array}$ & $\begin{array}{l}\text { Taxes based on ability to pay } \\
\text { Establishment of a trust fund to be } \\
\text { used only for the North Carolina Health } \\
\text { Plan }\end{array}$ \\
\hline
\end{tabular}




\begin{tabular}{|c|c|c|c|c|c|}
\hline Proposal/Bill & Author, Year & Payer & Eligibility & Coverage & Financing \\
\hline $\begin{array}{l}\text { Ohio Health } \\
\text { Security Act } \\
\text { (Ohio, SB } 104 \text { / } \\
\text { HB 121) }\end{array}$ & $\begin{array}{l}\text { State Senator } \\
\text { Michael J. } \\
\text { Skindell (D- } \\
\text { Lakewood) and } \\
\text { State } \\
\text { Representative } \\
\text { Senator Robert } \\
\text { Hagan (D- } \\
\text { Youngstown), } \\
2013\end{array}$ & $\begin{array}{l}\text { State } \\
\text { government as } \\
\text { the single } \\
\text { insurer, with } \\
\text { administration by } \\
\text { the Ohio health } \\
\text { care agency who } \\
\text { may act directly } \\
\text { or through } \\
\text { contractors }\end{array}$ & $\begin{array}{l}\text { All residents of } \\
\text { and employees } \\
\text { in Ohio are } \\
\text { eligible to enroll } \\
\text { in the Ohio } \\
\text { health care plan, } \\
\text { including the } \\
\text { homeless and } \\
\text { migrant workers } \\
\text { In-state } \\
\text { employers may } \\
\text { purchase the } \\
\text { Ohio health care } \\
\text { plan for non- } \\
\text { residents who } \\
\text { work in Ohio }\end{array}$ & $\begin{array}{l}\text { Comprehensive: including inpatient and } \\
\text { outpatient, emergency, rehabilitation, } \\
\text { mental health, substance abuse } \\
\text { treatment, hospice, home health, } \\
\text { preventive, dental, vision, hearing } \\
\text { services; prescription drugs; diagnostic } \\
\text { tests; medical supplies and equipment; } \\
\text { immunizations } \\
\text { Out-of-state employer benefits to be } \\
\text { the primary insurance and the health } \\
\text { care plan to be secondary } \\
\text { Emergency services to be covered for } \\
\text { non-residents }\end{array}$ & $\begin{array}{l}\text { Federal, state, and local governmental } \\
\text { funds, employer payroll tax (not to } \\
\text { exceed } 3.85 \% \text { of payroll in the first } \\
\text { year), business gross receipts tax (not } \\
\text { to exceed } 3 \% \text { of gross receipts), } \\
\text { income taxes ( } 6.2 \% \text { of income beyond } \\
\text { the amount subject to Social Security } \\
\text { payroll tax; } 5 \% \text { of adjusted gross } \\
\text { income }>\$ 200,000) \\
\text { Revenue and payments to be } \\
\text { transferred through the Ohio health } \\
\text { care fund }\end{array}$ \\
\hline $\begin{array}{l}\text { Illinois Universal } \\
\text { Health Care Act } \\
\text { (Illinois, HB 942) }\end{array}$ & $\begin{array}{l}\text { State } \\
\text { Representative } \\
\text { Mary Flowers } \\
\text { (D-Chicago), } \\
2013\end{array}$ & $\begin{array}{l}\text { State } \\
\text { government as } \\
\text { the single } \\
\text { insurer, with } \\
\text { administration by } \\
\text { the Illinois } \\
\text { Health Services } \\
\text { Governing Board }\end{array}$ & $\begin{array}{l}\text { All individuals } \\
\text { residing in } \\
\text { Illinois }\end{array}$ & $\begin{array}{l}\text { Comprehensive: all medically } \\
\text { necessary services, including primary, } \\
\text { preventive, specialty, inpatient, } \\
\text { outpatient, emergency care, long-term, } \\
\text { mental care, dental, substance abuse, } \\
\text { chiropractic, and vision services; } \\
\text { prescription drugs; durable medical } \\
\text { equipment }\end{array}$ & $\begin{array}{l}\text { State appropriations, federal funds, } \\
\text { income contributions ( } 20 \% \text { individuals, } \\
20 \% \text { businesses, } 60 \% \text { government), } \\
\text { and other tax revenues and funds } \\
\text { earmarked for health } \\
\text { Funds to be deposited into the Illinois } \\
\text { Health Services Trust, which will be } \\
\text { used for operating and capital } \\
\text { expenditures, provider payments, and } \\
\text { public health services }\end{array}$ \\
\hline $\begin{array}{l}\text { An act... relating } \\
\text { to: establishing a } \\
\text { publically } \\
\text { financed health } \\
\text { care system for } \\
\text { residents of this } \\
\text { state... } \\
\text { (Wisconsin, SB } \\
51 \text { ) }\end{array}$ & $\begin{array}{l}\text { State Senator } \\
\text { Mark Miller (D- } \\
\text { Monona), } 2007\end{array}$ & $\begin{array}{l}\text { State } \\
\text { government as } \\
\text { the single } \\
\text { insurer, with } \\
\text { administration by } \\
\text { the Department } \\
\text { of Health } \\
\text { Planning and } \\
\text { Finance with six } \\
\text { regional offices }\end{array}$ & $\begin{array}{l}\text { All residents of } \\
\text { Wisconsin }\end{array}$ & $\begin{array}{l}\text { Comprehensive: reasonable medical } \\
\text { services, including services provided by } \\
\text { health facilities and licensed } \\
\text { professionals; preventive, long-term, } \\
\text { mental health, and dental services; } \\
\text { medical supplies and equipment; blood } \\
\text { and blood products; prescription drugs } \\
\text { The health plan to be the payer } \\
\text { secondary to any other health coverage }\end{array}$ & $\begin{array}{l}\text { Federal, state, and local funds (as } \\
\text { allowed by waivers); employer tax; } \\
\text { individual income tax }\end{array}$ \\
\hline
\end{tabular}




\begin{tabular}{|c|c|c|c|c|c|}
\hline Proposal/Bill & Author, Year & Payer & Eligibility & Coverage & Financing \\
\hline $\begin{array}{l}\text { Minnesota } \\
\text { Health Plan } \\
\text { (Minnesota, HF } \\
76 \text { ) }\end{array}$ & $\begin{array}{l}\text { State } \\
\text { Representative } \\
\text { Carolyn Laine } \\
\text { (D-Columbia } \\
\text { Heights), } 2012\end{array}$ & $\begin{array}{l}\text { State } \\
\text { government as } \\
\text { the single } \\
\text { insurer, with } \\
\text { administration by } \\
\text { the Minnesota } \\
\text { Health Board }\end{array}$ & $\begin{array}{l}\text { All residents and } \\
\text { non-resident } \\
\text { employees of } \\
\text { Minnesota }\end{array}$ & $\begin{array}{l}\text { Comprehensive: all medically } \\
\text { necessary health services, including } \\
\text { inpatient, outpatient, preventive, mental } \\
\text { health, emergency, rehabilitative, home } \\
\text { health, skilled nursing, hospice, dental, } \\
\text { vision, substance abuse, chiropractic } \\
\text { podiatric, imaging, laboratory, dialysis, } \\
\text { and language services; prescription } \\
\text { drugs; medical equipment; blood } \\
\text { products; adult day care; acupuncture; } \\
\text { complementary and alternative } \\
\text { medicines; case management and care } \\
\text { coordination; health and wellness } \\
\text { education; other services previously } \\
\text { covered in state programs } \\
\text { The health plan to be the secondary } \\
\text { payer to existing federal programs }\end{array}$ & $\begin{array}{l}\text { The premium structure to be developed } \\
\text { by the Minnesota Health Board; the } \\
\text { structure to include income and } \\
\text { business health taxes based on ability } \\
\text { to pay and maximum premium cap } \\
\\
\text { Premiums and other revenue to be } \\
\text { deposited in the Minnesota Health } \\
\text { Fund, which will be used for payments } \\
\text { for health services }\end{array}$ \\
\hline $\begin{array}{l}\text { Colorado Health } \\
\text { Services Plan } \\
\text { (CHSP) Single } \\
\text { Payer Proposal } \\
\text { (Health Care for } \\
\text { all Colorado Act) }\end{array}$ & $\begin{array}{l}\text { Health Care for } \\
\text { All Colorado } \\
\text { Single Payer } \\
\text { Task Force, } \\
2012\end{array}$ & $\begin{array}{l}\text { State } \\
\text { government as } \\
\text { the single } \\
\text { insurer, with } \\
\text { administration by } \\
\text { the Colorado } \\
\text { Health Services } \\
\text { Governing Board } \\
\text { and } 7 \text { regional } \\
\text { districts }\end{array}$ & $\begin{array}{l}\text { All residents of } \\
\text { Colorado }\end{array}$ & $\begin{array}{l}\text { Comprehensive: all medically } \\
\text { necessary services, including primary } \\
\text { specialty (other than elective cosmetic), } \\
\text { inpatient, outpatient, emergency, long- } \\
\text { term, palliative, hospice, basic vision, } \\
\text { and basic hearing care; mental health, } \\
\text { dental (other than elective cosmetic); } \\
\text { substance abuse treatment, and } \\
\text { chiropractic services; prevention; health } \\
\text { education; ambulance; prescription } \\
\text { drugs; durable medical equipment; } \\
\text { autopsy; complementary alternative } \\
\text { medicine }\end{array}$ & $\begin{array}{l}\text { Health premium (tax) based on gross } \\
\text { income and family size, state } \\
\text { appropriations, payroll deductions, } \\
\text { federal funds; grants and contributions, } \\
\text { other funds earmarked for health care } \\
\text { Establishment of the Colorado Health } \\
\text { Services Trust }\end{array}$ \\
\hline
\end{tabular}




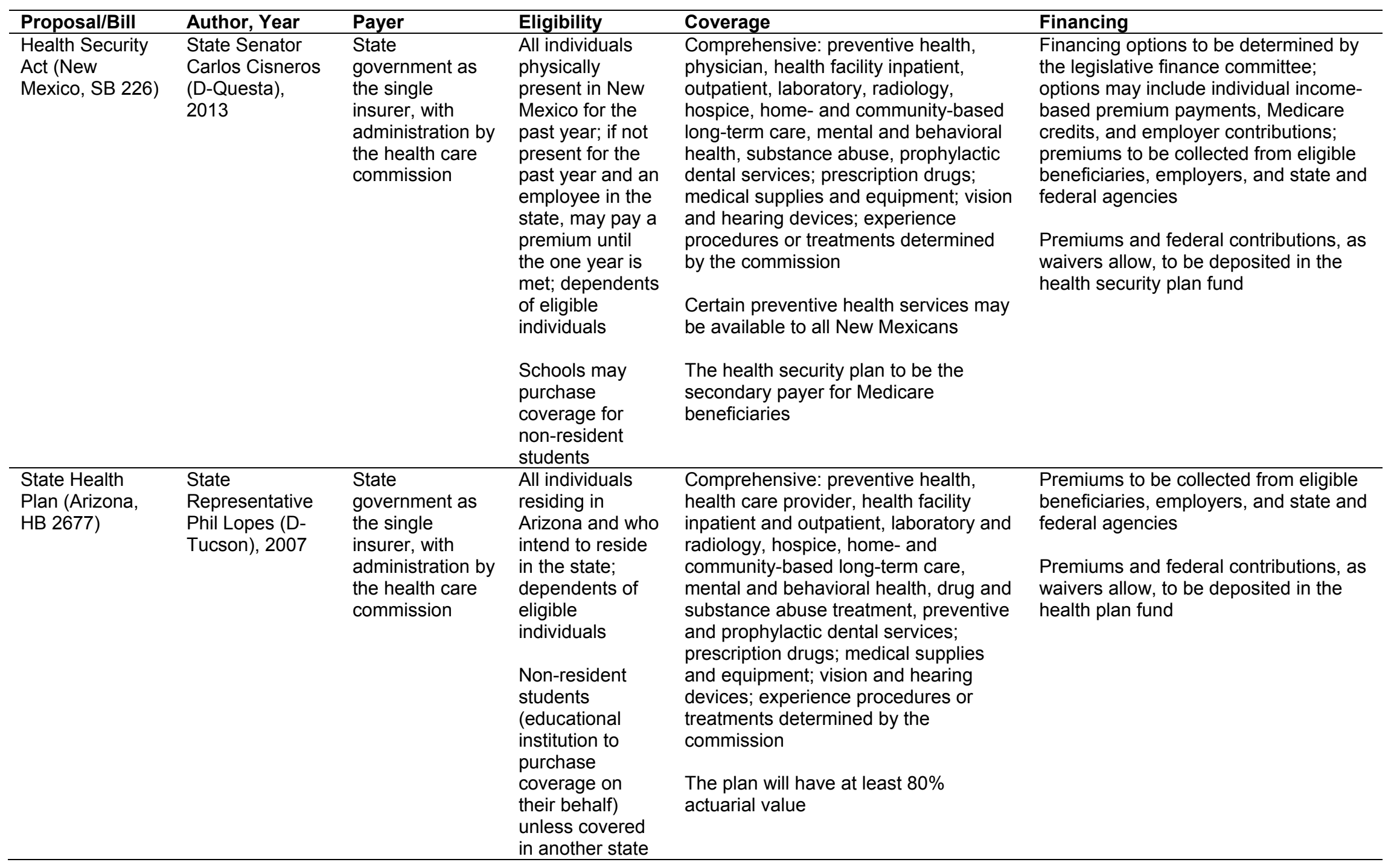




\begin{tabular}{|c|c|c|c|c|c|}
\hline Proposal/Bill & Author, Year & Payer & Eligibility & Coverage & Financing \\
\hline $\begin{array}{l}\text { California } \\
\text { Universal } \\
\text { Healthcare Act } \\
\text { (California, S } \\
\text { 810) }\end{array}$ & $\begin{array}{l}\text { State Senator } \\
\text { Mark Leno (D- } \\
\text { San Francisco), } \\
2012\end{array}$ & $\begin{array}{l}\text { State } \\
\text { government as } \\
\text { the single } \\
\text { insurer, with } \\
\text { administration by } \\
\text { the California } \\
\text { Healthcare } \\
\text { Agency }\end{array}$ & $\begin{array}{l}\text { All residents of } \\
\text { California }\end{array}$ & $\begin{array}{l}\text { Comprehensive: all medically } \\
\text { appropriate care, including inpatient } \\
\text { and outpatient, diagnostic and } \\
\text { laboratory, rehabilitation, emergency, } \\
\text { immunization and preventive, hospice, } \\
\text { home health, skilled nursing facility, } \\
\text { mental health, substance abuse } \\
\text { treatment, dental, chiropractic, family } \\
\text { planning, and language services; } \\
\text { health education; prescription drugs; } \\
\text { durable medical equipment; podiatry; } \\
\text { acupuncture; vision care; adult day } \\
\text { care; case management and } \\
\text { coordination; dialysis; chronic disease } \\
\text { management }\end{array}$ & $\begin{array}{l}\text { Premiums with a structure established } \\
\text { by the Healthcare Premium } \\
\text { Commission to maintain the current } \\
\text { distribution of healthcare contributions } \\
\text { from individuals, employers, } \\
\text { government and other; transfers from } \\
\text { the general fund }\end{array}$ \\
\hline $\begin{array}{l}\text { Affordable } \\
\text { Health Care for } \\
\text { All Oregon Plan } \\
\text { (Oregon, HB } \\
\text { 2992) }\end{array}$ & $\begin{array}{l}\text { State } \\
\text { Representative } \\
\text { Michael } \\
\text { Dembrow (D- } \\
\text { Portland), } 2013\end{array}$ & $\begin{array}{l}\text { State } \\
\text { government as } \\
\text { the single } \\
\text { insurer, with } \\
\text { administration by } \\
\text { the Oregon } \\
\text { Health Authority }\end{array}$ & $\begin{array}{l}\text { All individuals } \\
\text { who reside or } \\
\text { are employed in } \\
\text { Oregon, and } \\
\text { immediate family } \\
\text { members }\end{array}$ & $\begin{array}{l}\text { Comprehensive: medical necessary } \\
\text { health services, including primary, } \\
\text { preventive, specialty, inpatient, } \\
\text { outpatient, emergency, home health, } \\
\text { mental health, substance abuse } \\
\text { treatment, dental, chiropractic, } \\
\text { rehabilitative, emergency, midwife, } \\
\text { vision, diagnostic and laboratory, } \\
\text { hospice, and translation services; } \\
\text { prescription drugs; durable medical } \\
\text { equipment; podiatry; acupuncture; and } \\
\text { dialysis }\end{array}$ & $\begin{array}{l}\text { State appropriations, governmental } \\
\text { transfers, dedicated taxes } \\
\text { Progressive tax system to be } \\
\text { determined; may include an employer } \\
\text { payroll tax, personal income tax, } \\
\text { transaction tax on stocks and bonds, } \\
\text { unearned income tax, surtax on higher } \\
\text { incomes, and tax on gross business } \\
\text { receipts } \\
\text { Funds to be deposited in the Affordable } \\
\text { Health Care for All Oregon Fund, which } \\
\text { will be used for reimbursement for } \\
\text { health services }\end{array}$ \\
\hline $\begin{array}{l}\text { An act relating to } \\
\text { the Washington } \\
\text { health security } \\
\text { trust } \\
\text { (Washington, HB } \\
1085 \text { / SB 5224) }\end{array}$ & $\begin{array}{l}\text { State } \\
\text { Representative } \\
\text { Sherry Appleton } \\
\text { (D-Poulsbo), } \\
\text { State Senator } \\
\text { Jeanne Kohl- } \\
\text { Welles (D- } \\
\text { Seattle), } 2013\end{array}$ & $\begin{array}{l}\text { State } \\
\text { government as } \\
\text { the single } \\
\text { insurer, with } \\
\text { administration by } \\
\text { the Washington } \\
\text { health security } \\
\text { trust }\end{array}$ & $\begin{array}{l}\text { All residents of } \\
\text { Washington, i.e., } \\
\text { individuals who } \\
\text { have evidence of } \\
\text { established, } \\
\text { permanent } \\
\text { residency and } \\
\text { individuals } \\
\text { employed in the } \\
\text { state for at least } \\
\text { one month; } \\
\text { accompanying } \\
\text { family members }\end{array}$ & $\begin{array}{l}\text { Comprehensive: effective and } \\
\text { necessary personal health services, } \\
\text { including inpatient, outpatient, } \\
\text { emergency, home-based, office-based, } \\
\text { rehabilitation, mental health, substance } \\
\text { abuse treatment, vision and hearing, } \\
\text { and preventive services; prescription } \\
\text { drugs; durable medical equipment; } \\
\text { diagnostic tests } \\
\text { The health security trust to be the } \\
\text { secondary payer to any other insurance } \\
\text { Emergency services and transportation } \\
\text { to be covered for non-residents }\end{array}$ & $\begin{array}{l}\text { Monthly flat rate premium paid by } \\
\text { residents aged } \geq 18 \text { with incomes } \\
>150 \% \text { FPL (except Medicare and } \\
\text { Medicaid beneficiaries) - premium to } \\
\text { be determined by the board and } \\
\text { legislature - collected by employers } \\
\text { through payroll deduction; employer } \\
\text { health security assessment on gross } \\
\text { payroll; beer, cigarette, and spirits tax } \\
\text { revenue and tobacco settlement funds }\end{array}$ \\
\hline
\end{tabular}




\begin{tabular}{|c|c|c|c|c|c|}
\hline Proposal/Bill & Author, Year & Payer & Eligibility & Coverage & Financing \\
\hline $\begin{array}{l}\text { A bill for an act } \\
\text { relating to health } \\
\text { care (Hawaii, HB } \\
1617 \text { ) }\end{array}$ & $\begin{array}{l}\text { State } \\
\text { Representative } \\
\text { Calvin K. Y. Say } \\
\text { (D-Hawaii), } 2003\end{array}$ & $\begin{array}{l}\text { State } \\
\text { government as } \\
\text { the single } \\
\text { insurer, with } \\
\text { administration by } \\
\text { the state health } \\
\text { authority }\end{array}$ & $\begin{array}{l}\text { All citizens of } \\
\text { Hawaii }\end{array}$ & $\begin{array}{l}\text { Comprehensive: all optional services } \\
\text { under Medicaid; may include the } \\
\text { following services or a combination of } \\
\text { services: home health care, adult day } \\
\text { care, adult residential care home, } \\
\text { extended care adult residential care } \\
\text { home, nursing home, skilled nursing } \\
\text { facilities and intermediate care } \\
\text { facilities, hospice, assisted living } \\
\text { facility, personal care, respite care, } \\
\text { other care }\end{array}$ & $\begin{array}{l}\text { Personal income taxes, payroll } \\
\text { deductions, corporate income taxes, } \\
\text { and other funds to be determined; } \\
\text { federal Medicaid matching funds; state } \\
\text { general funds, health care portions of } \\
\text { insurance provider reimbursement } \\
\text { Funds to be deposited in the state } \\
\text { health authority fund }\end{array}$ \\
\hline
\end{tabular}


I identified twenty state-based proposals, including Vermont's single-payer bill that was enacted in 2011 (Ariz. 2007; Cal. 2012; Del. 2013; Ill. 2013; Mass. 2013; Md. 2014; Me. 2013; Minn. 2012; N.M. 2013; N.Y. 2013; Ohio 2013; Or. 2013; Pa. 2013; 2011 Vt. Acts \& Resolves 48; Wash. 2013; Wis. 2007). The state proposals originate from across the country, with 6 from the Northeast, 3 from the South, 4 from the Midwest, and 7 from the West. Thirteen states had state legislatures controlled by the Democratic Party in the year of the proposal, while 5 states had Republican-controlled legislatures and 2 states had legislatures in which neither party had majorities (National Conference of State Legislatures, 2016).

The state bills propose to establish agencies in the state government to administer a health care plan for all state residents. The bills vary in how they define residency for plan eligibility purposes. With the exception of Connecticut's bill simply stating the intention of establishing a single-payer system, all offer a comprehensive benefit package that covers hospital and physician services, as well as many other service categories. States such as Massachusetts and Illinois would convert all health care providers to non-profit status. The financing plans vary by state, with some bills containing a plan to develop a financing structure after further study; most consider a combination of taxes or premiums shared by employers and individuals, as well as the transfer of other federal, state, and local funds dedicated for health care. Most states would apply for federal waivers in order to move the Medicaid program under the single-payer program.

\section{Breadth across Health Care System Functions}

Figure 2.2 shows the percentage of proposals that contain provisions relating to the collection of funds, pooling of funds, purchasing of services, and provision of services in terms of covered benefits and provider eligibility. Nearly all (23) of the proposals include provisions spanning the four main health care system functions. In these 23 proposals ( $92 \%)$, the collection of funds is 
typically described as the type of revenue sources, including contributions in the form of taxes or premiums and, in the case of state-based proposals, federal funds. Residency is most often used to define the eligible population that is included in the single pool. The proposals vary in how allocation of funds from the single payer to health care providers would occur, with some proposals allowing fee-for-service, global budgets, population-based payments, or combinations thereof. Other proposals call for studies on payment models before implementing reforms. Measures addressing the provision of services include specification of covered services and how the covered services would be determined. Within these 23 proposals, all except the Maryland and Hawaii bills also include specifications for the eligibility of the health care providers who may participate in the program.

Figure 2.2. Breadth of Proposals across Health Care System Functions

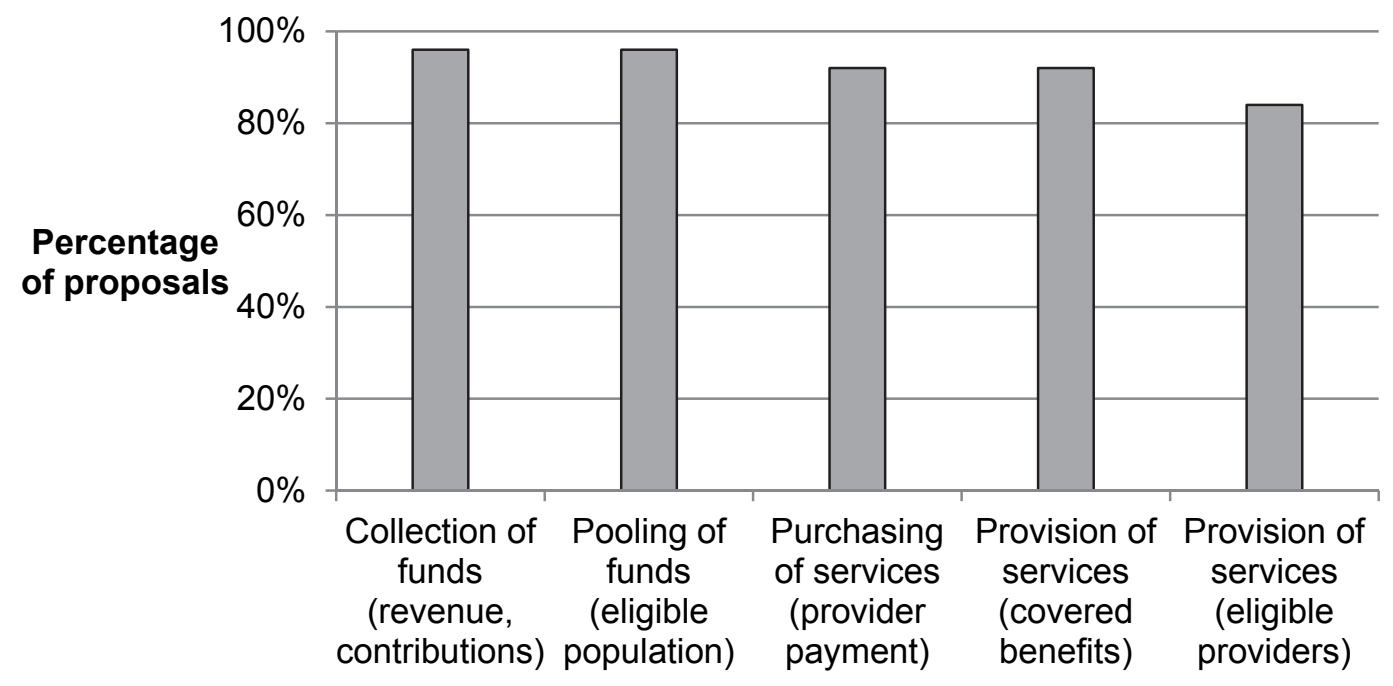

Health care system functions included in proposals

The two exceptions that do not address all four health care system systems functions are the Connecticut bill and the Health-Insurance Solution. The Connecticut bill is a brief document that simply states the intention to create a single-payer system, without any details on the design and implementation. The Health-Insurance Solution details fund collection and the pooling of funds 
for a specified population; however, it is the only proposal reviewed that has a plan based on catastrophic, income-dependent coverage rather than a comprehensive package of benefits. This proposal for catastrophic coverage does not include specific changes to provider payment, covered services, and eligibility of providers.

Provisions towards Increased Access, Improved Quality, and Reduced Costs

Figure 2.3 shows a summary of the common provisions affecting access to care, quality of care, and health care costs that are contained in the 25 single-payer proposals. Details on the proposals containing each provision are shown in Tables 2.3, 2.4 and 2.5. The omission of any provision from a proposal does not preclude adoption of the provision at a later time; many provisions have details to be determined after additional study. Further details about the provisions contained in each proposal are in Appendix A.

Figure 2.3. Common Access, Quality, and Cost Provisions in the Proposals

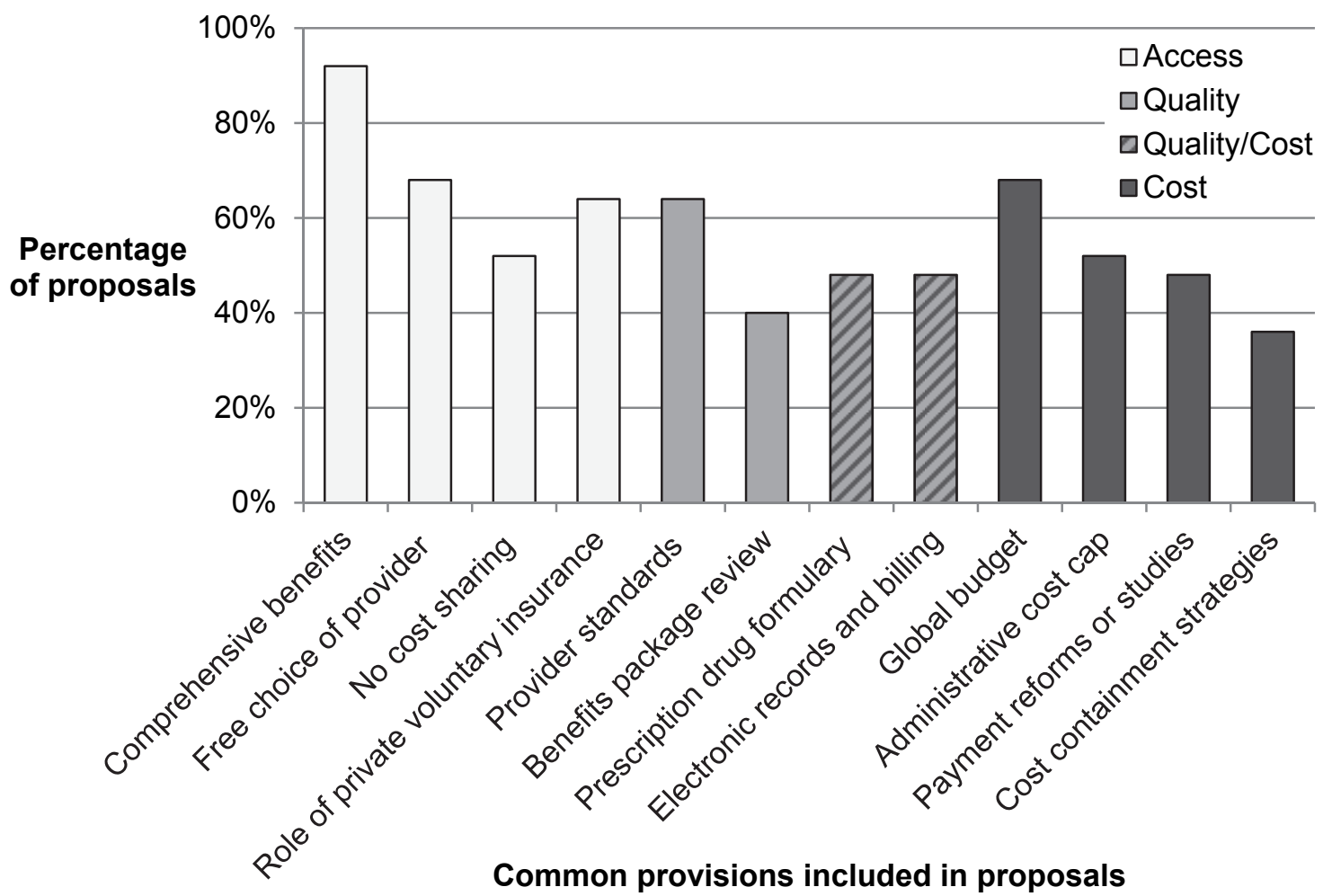




\section{Access}

Several provisions aim to improve access to care (Table 2.3). Access to care depends on access to insurance, covered benefits, cost sharing, and access to providers. With the exception of the Health-Insurance Solution (catastrophic coverage) and the Connecticut bill (coverage unspecified), 23 proposals (92\%) aim to cover eligible residents for a "comprehensive" benefit package, meaning that at least basic hospital and medical services are included. The inclusion of "all medically necessary health care" is mentioned in 11 proposals (44\%). Some include dental, vision, long-term care, and prescription drugs benefits, while others plan to conduct studies to determine whether these benefits will be included in the statutory benefit package. About half of the proposals also specify that there would be no cost sharing in the form of copayments, coinsurance, and deductibles; 6 state proposals (24\%) leave the decision on cost sharing to be determined at a later date following analyses.

In terms of provider choice, 17 proposals $(68 \%)$ note that patients will have free choice of providers (i.e., no network restrictions); this extends only to primary care providers in 4 bills $(16 \%)$ that require referrals for specialty care. A restriction on access to specialists is an example of supply control that may be possible at a greater extent with a single payer than multiple payers.

The role of private voluntary health insurance is discussed in 16 proposals $(64 \%)$, ranging from the prohibition of substitutive (i.e., duplicative) and supplementary insurance to the prohibition of only substitutive insurance to no mention of restrictions on private insurance. Of these, 9 proposals (36\%) allow some type of private voluntary health insurance. None of the proposals prohibit complementary private insurance.

Many bills specify the establishment of an enrollment system, and 8 bills (32\%) address some barriers to enrollment. Pennsylvania, Ohio and California explicitly note that the 
enrollment system shall be made accessible to individuals with language and literacy barriers. Other bills (Illinois, Wisconsin, Colorado, New Mexico, and Arizona) note that social security numbers would not be used for identification. Initiatives to ensure adequate resources and programs in underserved and rural areas are included in 9 bills (36\%). Out-of-state issues, such as reimbursement for out-of-state services and reciprocity agreements with other states, are discussed in 9 bills (36\%). In addition, 8 state bills (32\%) include some monitoring of access to care, e.g., annual reviews of access and unmet needs, local committees or offices to monitor access and receive public input, and quality assurance standards for access.

\section{Quality}

The provisions addressing quality of care vary across the bills. Common themes include the review of benefits and utilization of services, provider practice guidelines and quality standards, models of care and innovation, a workforce able to deliver quality care, care coordination, public reporting of quality ratings and prices, electronic health records and billing systems, and formularies (Table 2.4). Several of the provisions that address quality are also related to cost.

The use of guidelines and quality standards for health care providers or monitoring of provider practices is included in 16 proposals (64\%). An annual or periodic review of benefits and recommendations to remove or add benefits based on value and safety is mentioned in 10 proposals (40\%); 4 proposals (19\%) specifically mention that ineffective services would be excluded and 3 proposals (12\%) mention the promotion of preventive services. The determination of ineffective care generally involves a board of medical professionals to determine which services and procedures are deemed appropriate. Further studies on care delivery models and cost effectiveness are mentioned in 3 proposals (12\%): the American Health Security Act would study new models of care towards achieving the Triple Aim, and New 
Mexico and Arizona would study cost-effective methods to deliver quality care. Promotion of preventive care is included in 2 state bills (8\%): Massachusetts would promote preventive care by funding initiatives and outreach, while the Maryland proposes to provide incentives to individuals. Care coordination is discussed in 2 state bills (8\%), with the New York bill specifying that provider payment would be contingent on beneficiary enrollment with a care coordinator.

The establishment of funds for medical research and innovation is proposed in 4 bills (16\%), and 4 bills (16\%) provide funds for health care workforce training. Various provider payment mechanisms are discussed, but most bills leave this largely unspecified and include plans to conduct studies to determine appropriate payment mechanisms. However, 4 bills (16\%) do note that adequate provider payments are necessary in order to retain talented providers, particularly at the state level, and to maintain quality of care. The Health-Insurance Solution would establish a database of quality ratings and prices that consumers could access.

The establishment of electronic systems for patient records, claims, and payments would have implications for both quality and cost, and is proposed in 14 proposals (56\%). Also spanning both quality and cost, 13 proposals (52\%) include national or state level formularies for prescription drugs and medical supplies to allow for more standardization of the use of efficacious and cost-effective medications and the negotiation of prices with bulk purchasing.

\section{Cost}

The most common cost provision was global budgets for total expenditures, which is included in 17 proposals (68\%) [Table 2.5]. The global budget is typically set based on prior year expenditures and projected growth in gross domestic (or state) product. Bills also often specify budgets for components of total expenditures, such as for capital and operating expenditures. 
Over half (52\%) of proposals included provisions to set a maximum threshold for administrative costs at a proportion of total expenditures (e.g., 5 percent).

In terms of provider payment, 10 bills (40\%) have hospitals and health maintenance organizations operate on a global institutional budget based on capitation. Demonstrations or other studies of models of provider payment are mentioned in 3 bills (12\%). Various other cost control mechanisms are mentioned as possible strategies to be implemented when needed. Moreover, 9 bills (36\%) would grant authority to the system's board and administrators to put cost containment strategies in place in the future if deemed necessary. Price negotiations for drug and medical supplies between the single-payer agency and manufacturers and suppliers are mentioned in 8 state bills (32\%). Five proposals (20\%) include plans to study cost containment approaches. Three state bills (12\%) include measures to investigate medical fraud, and 2 state bills (8\%) - New Mexico and Arizona - would study migration effects. The Health-Insurance Solution proposes to eliminate the tax exclusion of premium contributions for employersponsored insurance. 
Table 2.3. Measures towards Increased Access

\begin{tabular}{|c|c|c|c|c|c|c|c|c|c|c|c|c|c|}
\hline Proposal/Bill & $\begin{array}{c}\text { Hospital, } \\
\text { medical } \\
\text { benefits }\end{array}$ & $\begin{array}{c}\text { Dental } \\
\text { benefits }\end{array}$ & $\begin{array}{c}\text { Vision } \\
\text { benefits }\end{array}$ & $\begin{array}{l}\text { Long- } \\
\text { term care } \\
\text { benefits }\end{array}$ & $\begin{array}{l}\text { Prescrip- } \\
\text { tion drug } \\
\text { benefits }\end{array}$ & $\begin{array}{l}\text { No cost } \\
\text { sharing }\end{array}$ & $\begin{array}{c}\text { Enroll- } \\
\text { ment } \\
\text { issues }\end{array}$ & $\begin{array}{c}\text { Free } \\
\text { choice of } \\
\text { provider }\end{array}$ & $\begin{array}{c}\text { No } \\
\text { specialist } \\
\text { referral }\end{array}$ & $\begin{array}{c}\text { Private } \\
\text { insurance } \\
\text { allowed }\end{array}$ & $\begin{array}{l}\text { Under- } \\
\text { served } \\
\text { areas }\end{array}$ & $\begin{array}{l}\text { Out-of- } \\
\text { state } \\
\text { issues }\end{array}$ & $\begin{array}{c}\text { Monitor } \\
\text { access } \\
\text { issues }\end{array}$ \\
\hline PNHP, 2003 & $\checkmark$ & $\checkmark$ & & $\checkmark$ & $\checkmark$ & $\checkmark$ & & & & & & & \\
\hline $\begin{array}{l}\text { Health-Insurance } \\
\text { Solution, } 2012\end{array}$ & & & & & & $x$ & & & & $\checkmark$ & & & \\
\hline $\begin{array}{l}\text { Medicare For All } \\
\text { Act, } 2013\end{array}$ & $\checkmark$ & $\checkmark$ & $\checkmark$ & $\checkmark$ & $\checkmark$ & $\checkmark$ & & & & $\begin{array}{l}\checkmark \text { comp, } \\
\times \text { no subs }\end{array}$ & & & \\
\hline $\begin{array}{l}\text { American Health } \\
\text { Security, } 2013\end{array}$ & $\checkmark$ & $\checkmark$ & $\begin{array}{c}\checkmark \\
\text { children }\end{array}$ & $\checkmark$ & $\checkmark$ & $\checkmark$ & & & & & & $\checkmark$ & \\
\hline $\begin{array}{l}\text { National Health } \\
\text { Insurance, } 2009\end{array}$ & $\checkmark$ & $\checkmark$ & $\begin{array}{c}\checkmark \\
\text { glasses } \\
\end{array}$ & & $\begin{array}{l}\checkmark \text { expen- } \\
\text { sive drugs }\end{array}$ & $\begin{array}{c}\boldsymbol{x} \text { other } \\
\text { services }\end{array}$ & & $\begin{array}{l}\checkmark \text { primary } \\
\text { provider }\end{array}$ & $x$ & & & & \\
\hline Vermont, 2011 & $\checkmark$ & TBD & & & & TBD & & & & TBD & & & \\
\hline Maine, 2013 & $\checkmark$ & $\checkmark$ & $\checkmark$ & TBD & $\checkmark$ & TBD & & $\checkmark$ & & $\begin{array}{l}\checkmark \text { comp, } \\
\times \text { no subs } \\
\end{array}$ & $\checkmark$ & $\checkmark$ & \\
\hline $\begin{array}{l}\text { Massachusetts, } \\
2013\end{array}$ & $\checkmark$ & $\checkmark$ & $\checkmark$ & $\checkmark$ & $\checkmark$ & $\checkmark$ & & $\checkmark$ & & $x$ no subs & $\checkmark$ & & $\checkmark$ \\
\hline \multicolumn{14}{|l|}{$\begin{array}{l}\text { Connecticut, } \\
2013\end{array}$} \\
\hline New York, 2013 & $\checkmark$ & & & & & $\checkmark$ & & $\checkmark$ & & $x$ no subs & & & \\
\hline $\begin{array}{l}\text { Pennsylvania, } \\
2013\end{array}$ & $\checkmark$ & $\checkmark$ & $\checkmark$ & $\checkmark$ & $\checkmark$ & $\checkmark$ & $\checkmark$ & $\checkmark$ & $\checkmark$ & $\checkmark$ & & & $\checkmark$ \\
\hline Maryland, 2014 & $\checkmark$ & TBD & TBD & TBD & & & & & & & & & \\
\hline Delaware, 2013 & $\checkmark$ & $\checkmark$ & $\checkmark$ & & $\checkmark$ & & & $\checkmark$ & & & & & \\
\hline $\begin{array}{l}\text { North Carolina, } \\
2013\end{array}$ & $\checkmark$ & $\checkmark$ & & $\checkmark$ & $\checkmark$ & $v^{a}$ & & $\checkmark$ & $x^{b}$ & & & & \\
\hline Ohio, 2013 & $\checkmark$ & $\checkmark$ & $\checkmark$ & & $\checkmark$ & $\checkmark$ & $\checkmark$ & $\checkmark$ & & $x$ no subs & $\checkmark$ & & \\
\hline Illinois, 2013 & $\checkmark$ & $\checkmark$ & $\checkmark$ & $\checkmark$ & $\checkmark$ & $\checkmark$ & $\checkmark$ & $\checkmark$ & & $\begin{array}{l}\checkmark \text { comp, } \\
\times \text { no subs } \\
\end{array}$ & & & \\
\hline Wisconsin, 2007 & $\checkmark$ & & $\begin{array}{c}\checkmark \\
\text { glasses } \\
\end{array}$ & $\checkmark$ & $\checkmark$ & $\checkmark$ & $\checkmark$ & $\checkmark$ & & $\begin{array}{c}\checkmark \\
\text { comp } \\
\end{array}$ & $\checkmark$ & & $\checkmark$ \\
\hline Minnesota, 2012 & $\checkmark$ & $\checkmark$ & $\checkmark$ & $\checkmark$ & $\checkmark$ & $\checkmark$ & & $\checkmark$ & $\checkmark$ & $x$ no subs & $\checkmark$ & $\checkmark$ & $\checkmark$ \\
\hline Colorado, 2012 & $\checkmark$ & $\checkmark$ & $\checkmark$ & $\checkmark$ & $\checkmark$ & $\checkmark$ & $\checkmark$ & $\checkmark$ & & $\begin{array}{l}\checkmark \text { comp, } \\
\times \text { no subs } \\
\end{array}$ & $\checkmark$ & $\checkmark$ & \\
\hline $\begin{array}{l}\text { New Mexico, } \\
2013\end{array}$ & $\checkmark$ & $\checkmark$ & $\checkmark$ & $\checkmark$ & $\checkmark$ & TBD & $\checkmark$ & $\begin{array}{l}\checkmark \text { primary } \\
\text { provider }\end{array}$ & $x$ & $x$ no subs & $\checkmark$ & $\checkmark$ & $\checkmark$ \\
\hline Arizona, 2007 & $\checkmark$ & $\checkmark$ & $\checkmark$ & $\checkmark$ & $\checkmark$ & TBD & $\checkmark$ & $\begin{array}{l}\checkmark \text { primary } \\
\text { provider }\end{array}$ & $x$ & $x$ no subs & $\checkmark$ & $\checkmark$ & $\checkmark$ \\
\hline California, 2012 & $\checkmark$ & $\checkmark$ & $\checkmark$ & $\checkmark$ & $\checkmark$ & TBD & $\checkmark$ & $\begin{array}{l}\checkmark \text { primary } \\
\text { provider }\end{array}$ & $x$ & $\begin{array}{c}\text { x no supp, } \\
\text { no subs }\end{array}$ & & $\checkmark$ & \\
\hline
\end{tabular}




\begin{tabular}{|c|c|c|c|c|c|c|c|c|c|c|c|c|c|}
\hline Proposal/Bill & $\begin{array}{c}\text { Hospital, } \\
\text { medical } \\
\text { benefits }\end{array}$ & $\begin{array}{c}\text { Dental } \\
\text { benefits }\end{array}$ & $\begin{array}{l}\text { Vision } \\
\text { benefits }\end{array}$ & $\begin{array}{c}\text { Long- } \\
\text { term care } \\
\text { benefits }\end{array}$ & $\begin{array}{l}\text { Prescrip- } \\
\text { tion drug } \\
\text { benefits }\end{array}$ & $\begin{array}{l}\text { No cost } \\
\text { sharing }\end{array}$ & $\begin{array}{c}\text { Enroll- } \\
\text { ment } \\
\text { issues }\end{array}$ & $\begin{array}{c}\text { Free } \\
\text { choice of } \\
\text { provider }\end{array}$ & $\begin{array}{c}\text { No } \\
\text { specialist } \\
\text { referral }\end{array}$ & $\begin{array}{c}\text { Private } \\
\text { insurance } \\
\text { allowed }\end{array}$ & $\begin{array}{l}\text { Under- } \\
\text { served } \\
\text { areas }\end{array}$ & $\begin{array}{l}\text { Out-of- } \\
\text { state } \\
\text { issues }\end{array}$ & $\begin{array}{c}\text { Monitor } \\
\text { access } \\
\text { issues }\end{array}$ \\
\hline Oregon, 2013 & $\checkmark$ & $\checkmark$ & $\checkmark$ & TBD & $\checkmark$ & $\checkmark$ & & $\checkmark$ & & $\begin{array}{l}\checkmark \text { public } \\
\text { workers }\end{array}$ & $\checkmark$ & & $\checkmark$ \\
\hline $\begin{array}{l}\text { Washington, } \\
2013\end{array}$ & $\checkmark$ & TBD & $\checkmark$ & TBD & $\checkmark$ & TBD & & $\checkmark$ & & $\begin{array}{c}\checkmark \\
\text { comp }\end{array}$ & & $\checkmark$ & $\checkmark$ \\
\hline Hawaii, 2003 & $\checkmark$ & & & TBD & & & & & & & & $\checkmark$ & \\
\hline $\begin{array}{l}\text { Number of } \\
\text { proposals (\%) }\end{array}$ & $\begin{array}{l}23 \\
(92)\end{array}$ & $\begin{array}{c}17 \\
(68)\end{array}$ & $\begin{array}{c}17 \\
(68)\end{array}$ & $\begin{array}{c}13 \\
(52)\end{array}$ & $\begin{array}{c}18 \\
(72)\end{array}$ & $\begin{array}{c}13 \\
(52)\end{array}$ & $\begin{array}{c}8 \\
(32)\end{array}$ & $\begin{array}{c}17 \\
(68)\end{array}$ & $\begin{array}{c}2 \\
(8)\end{array}$ & $\begin{array}{c}9 \\
(36)\end{array}$ & $\begin{array}{c}9 \\
(36)\end{array}$ & $\begin{array}{c}9 \\
(36)\end{array}$ & $\begin{array}{c}8 \\
(32)\end{array}$ \\
\hline
\end{tabular}

$\checkmark=$ yes, $x=$ no, gray=not mentioned; comp=complementary, supp=supplementary, subs=substitutive.

${ }^{a}$ First two years, TBD thereafter

${ }^{\mathrm{b}}$ Copayment or deductible may be charged for a specialist care if no referral from a primary care provider 
Table 2.4. Measures towards Improved Quality

\begin{tabular}{|c|c|c|c|c|c|c|c|c|c|c|c|c|}
\hline Proposal/Bill & $\begin{array}{c}\text { Provider } \\
\text { standards, } \\
\text { monitoring }\end{array}$ & $\begin{array}{c}\text { Review } \\
\text { benefits } \\
\text { package }\end{array}$ & $\begin{array}{c}\text { Reduce } \\
\text { ineffec- } \\
\text { tive care } \\
\end{array}$ & $\begin{array}{c}\text { Promote } \\
\text { preven- } \\
\text { tion }\end{array}$ & $\begin{array}{c}\text { Study } \\
\text { models } \\
\text { of care }\end{array}$ & $\begin{array}{c}\text { Care } \\
\text { coordi- } \\
\text { nation }^{a} \\
\end{array}$ & $\begin{array}{l}\text { Research } \\
\text { \& inno- } \\
\text { vation } \\
\end{array}$ & $\begin{array}{l}\text { Work- } \\
\text { force } \\
\text { training }\end{array}$ & $\begin{array}{c}\text { Adequate } \\
\text { payment } \\
\text { rates }^{\mathrm{a}}\end{array}$ & $\begin{array}{l}\text { Quality } \\
\text { ratings, } \\
\text { prices }^{\mathrm{a}}\end{array}$ & $\begin{array}{c}\text { EHRs, } \\
\text { e- } \\
\text { billing }^{a}\end{array}$ & Formulary* \\
\hline PNHP, 2003 & & & $\checkmark$ & & & & & & & & & $\checkmark$ \\
\hline $\begin{array}{l}\text { Health-Insurance } \\
\text { Solution, } 2012\end{array}$ & & & & & & & & & & $\checkmark$ & & \\
\hline $\begin{array}{l}\text { Medicare For All Act, } \\
2013\end{array}$ & $\checkmark$ & & & & & & & & & & $\checkmark$ & \\
\hline $\begin{array}{l}\text { American Health } \\
\text { Security, } 2013\end{array}$ & $\checkmark$ & & & & $\checkmark$ & & & & & & $\checkmark$ & \\
\hline $\begin{array}{l}\text { National Health } \\
\text { Insurance, } 2009\end{array}$ & & $\checkmark$ & & & & & & & $\checkmark$ & & & \\
\hline Vermont, 2011 & & & & & & & & & $\checkmark$ & & & $\checkmark$ \\
\hline Maine, 2013 & $\checkmark$ & & & & & & & & $\checkmark$ & & & $\checkmark$ \\
\hline Massachusetts, 2013 & $\checkmark$ & & & $\checkmark$ & & & $\checkmark$ & $\checkmark$ & & & $\checkmark$ & \\
\hline \multicolumn{13}{|l|}{ Connecticut, 2013} \\
\hline New York, 2013 & $\checkmark$ & & & & & $\checkmark$ & & & & & & \\
\hline Pennsylvania, 2013 & $\checkmark$ & & & & & & & & $\checkmark$ & & $\checkmark$ & \\
\hline Maryland, 2014 & & & & $\checkmark$ & & & & & & & & \\
\hline Delaware, 2013 & $\checkmark$ & $\checkmark$ & & & & & & & & & & \\
\hline North Carolina, 2013 & & & & & & & & & & & $\checkmark$ & $\checkmark$ \\
\hline Ohio, 2013 & $\checkmark$ & $\checkmark$ & $\checkmark$ & & & & $\checkmark$ & & & & $\checkmark$ & $\checkmark$ \\
\hline Illinois, 2013 & $\checkmark$ & $\checkmark$ & & & & & & & & & $\checkmark$ & $\checkmark$ \\
\hline Wisconsin, 2007 & $\checkmark$ & & & & & & & & & & & $\checkmark$ \\
\hline Minnesota, 2012 & & $\checkmark$ & & & & & $\checkmark$ & & & & $\checkmark$ & \\
\hline Colorado, 2012 & $\checkmark$ & & & $\checkmark$ & & & & $\checkmark$ & & & $\checkmark$ & $\checkmark$ \\
\hline New Mexico, 2013 & $\checkmark$ & $\checkmark$ & $\checkmark$ & & $\checkmark$ & & & & & & $\checkmark$ & $\checkmark$ \\
\hline Arizona, 2007 & $\checkmark$ & $\checkmark$ & $\checkmark$ & & $\checkmark$ & & & & & & $\checkmark$ & $\checkmark$ \\
\hline California, 2012 & $\checkmark$ & & & & & $\checkmark$ & & & & & $\checkmark$ & $\checkmark$ \\
\hline Oregon, 2013 & $\checkmark$ & $\checkmark$ & & & & & & $\checkmark$ & & & $\checkmark$ & $\checkmark$ \\
\hline Washington, 2013 & $\checkmark$ & $\checkmark$ & & & & & $\checkmark$ & $\checkmark$ & & & $\checkmark$ & $\checkmark$ \\
\hline Hawaii, 2003 & & $\checkmark$ & & & & & & & & & & \\
\hline $\begin{array}{l}\text { Number of proposals } \\
(\%)\end{array}$ & $\begin{array}{c}16 \\
(64) \\
\end{array}$ & $\begin{array}{c}10 \\
(40)\end{array}$ & $\begin{array}{c}4 \\
(16) \\
\end{array}$ & $\begin{array}{c}3 \\
(12) \\
\end{array}$ & $\begin{array}{c}3 \\
(12)\end{array}$ & $\begin{array}{c}2 \\
(8)\end{array}$ & $\begin{array}{c}4 \\
(16) \\
\end{array}$ & $\begin{array}{c}4 \\
(16) \\
\end{array}$ & $\begin{array}{c}4 \\
(16) \\
\end{array}$ & $\begin{array}{c}1 \\
(4)\end{array}$ & $\begin{array}{c}14 \\
(56) \\
\end{array}$ & $\begin{array}{c}13 \\
(52) \\
\end{array}$ \\
\hline
\end{tabular}

$\checkmark=y e s$, gray=not mentioned; EHRs=electronic health records;

${ }^{a}$ also towards reduced costs 
Table 2.5. Measures towards Reduced Costs

\begin{tabular}{|c|c|c|c|c|c|c|c|c|c|c|}
\hline Proposal/Bill & $\begin{array}{c}\text { Global } \\
\text { budget for } \\
\text { total costs }\end{array}$ & $\begin{array}{l}\text { Adminis- } \\
\text { trative cost } \\
\text { threshold }\end{array}$ & $\begin{array}{c}\text { Institutional } \\
\text { provider } \\
\text { budgets }\end{array}$ & $\begin{array}{c}\text { Study provi- } \\
\text { der payment } \\
\text { models }\end{array}$ & $\begin{array}{c}\text { May imple- } \\
\text { ment cost } \\
\text { controls }\end{array}$ & $\begin{array}{c}\text { Drug price } \\
\text { nego- } \\
\text { tiation }\end{array}$ & $\begin{array}{c}\text { Study cost } \\
\text { control } \\
\text { strategies }\end{array}$ & $\begin{array}{c}\text { Investigate } \\
\text { medical } \\
\text { fraud }\end{array}$ & $\begin{array}{c}\text { Assess } \\
\text { migration } \\
\text { effects }\end{array}$ & $\begin{array}{c}\text { Eliminate } \\
\text { employer tax } \\
\text { subsidies }\end{array}$ \\
\hline PNHP, 2003 & $\checkmark$ & & $\checkmark$ & & & & & & & \\
\hline $\begin{array}{l}\text { Health-Insurance } \\
\text { Solution, } 2012\end{array}$ & & & & & & & & & & $\checkmark$ \\
\hline $\begin{array}{l}\text { Medicare For All Act, } \\
2013\end{array}$ & $\checkmark$ & & $\checkmark$ & & & & & & & \\
\hline $\begin{array}{l}\text { American Health } \\
\text { Security, } 2013\end{array}$ & $\checkmark$ & $\checkmark 3 \%$ & & & & & & & & \\
\hline $\begin{array}{l}\text { National Health } \\
\text { Insurance, } 2009\end{array}$ & $\checkmark$ & $\checkmark 5 \%$ & & & $\checkmark$ & & $\checkmark$ & & & \\
\hline Vermont, 2011 & $\checkmark$ & & & $\checkmark$ & & & $\checkmark$ & & & \\
\hline Maine, 2013 & $\checkmark$ & $\checkmark 10 \%$ & $\checkmark$ & & $\checkmark$ & & & & & \\
\hline Massachusetts, 2013 & $\checkmark$ & $\checkmark 5 \%$ & & & & $\checkmark$ & & & & \\
\hline \multicolumn{11}{|l|}{ Connecticut, 2013} \\
\hline New York, 2013 & & & & $\checkmark$ & & & & & & \\
\hline Pennsylvania, 2013 & & $\checkmark 5 \%$ & & & $\checkmark$ & & & & & \\
\hline Maryland, 2014 & & & $\checkmark$ & & & & & & & \\
\hline Delaware, 2013 & $\begin{array}{l}\checkmark \text { operating } \\
\text { and capital }\end{array}$ & & & & & $\checkmark$ & & & & \\
\hline \multicolumn{11}{|l|}{ North Carolina, 2013} \\
\hline Ohio, 2013 & $\checkmark$ & $\checkmark 5 \%$ & & & $\checkmark$ & & & $\checkmark$ & & \\
\hline Illinois, 2013 & $\checkmark$ & $\checkmark 12,8,5 \%^{a}$ & $\checkmark$ & & & $\checkmark$ & & & & \\
\hline Wisconsin, 2007 & $\checkmark$ & & & & & $\checkmark$ & $\checkmark$ & & & \\
\hline Minnesota, 2012 & $\checkmark$ & & $\checkmark$ & & & & & $\checkmark$ & & \\
\hline Colorado, 2012 & & $\checkmark 12,8,5 \%^{a}$ & optional & & & $\checkmark$ & & & & \\
\hline New Mexico, 2013 & $\checkmark$ & $\checkmark 5 \%^{b}$ & $\checkmark$ & & $\checkmark$ & & & & $\checkmark$ & \\
\hline Arizona, 2007 & $\checkmark$ & $\checkmark 5 \%^{b}$ & $\checkmark$ & & $\checkmark$ & & & & $\checkmark$ & \\
\hline California, 2012 & $\checkmark$ & $\checkmark 10,5 \%^{\mathrm{c}}$ & & & $\checkmark$ & $\checkmark$ & $\checkmark$ & $\checkmark$ & & \\
\hline Oregon, 2013 & $\checkmark$ & $\checkmark 12,8,5 \%^{a}$ & & & $\checkmark$ & $\checkmark$ & & & & \\
\hline Washington, 2013 & $\checkmark$ & $\checkmark 11 \%$ & $\checkmark$ & $\checkmark$ & $\checkmark$ & $\checkmark$ & & & & \\
\hline Hawaii, 2003 & & & & & & & $\checkmark$ & & & \\
\hline $\begin{array}{l}\text { Number of proposals } \\
(\%)\end{array}$ & $\begin{array}{c}17 \\
(68)\end{array}$ & $\begin{array}{c}13 \\
(52)\end{array}$ & $\begin{array}{c}10 \\
(40)\end{array}$ & $\begin{array}{c}3 \\
(12) \\
\end{array}$ & $\begin{array}{c}9 \\
(36)\end{array}$ & $\begin{array}{c}8 \\
(32)\end{array}$ & $\begin{array}{c}5 \\
(20)\end{array}$ & $\begin{array}{c}3 \\
(12)\end{array}$ & $\begin{array}{c}2 \\
(8)\end{array}$ & $\begin{array}{c}1 \\
(4)\end{array}$ \\
\hline
\end{tabular}

$\checkmark=$ yes, gray=not mentioned

${ }^{a}$ First 2 years, next 2 years, subsequent years

${ }^{\mathrm{b}}$ Starting in the 6th year

${ }^{\mathrm{c}}$ First 5 years, within 10 years 


\section{Discussion}

Challenges and calls for the repeal of the ACA have persisted and many states have proposed health reform legislation, among them single-payer bills. As the political conversation on ways to improve the health care system continues, it is useful to understand fully what is meant by single-payer and the content of single-payer proposals.

Although a single-payer system is typically defined primarily as a financing mechanism for universal insurance coverage, legislators and researchers have proposed single-payer systems as comprehensive reform packages, with changes across all health care system functions and aims to improve access, quality, and cost containment. Many of the commonly identified provisions in the proposals are not unique to single-payer systems, but could potentially be achieved to a greater extent or at a broader scale with a single payer.

The single-payer proposals are generally consistent with the body of single-payer definitions, but do include provisions beyond what is typically defined as a single-payer system. Like the definitions, the proposals often include information about the payer, revenue collection, eligible population, plan coverage, and jurisdiction. Characteristics that are mentioned in only a few of the definitions, e.g., eligible providers, provider payment models, the role of private insurance, limits on administrative costs, and cost containment strategies, are also include in several proposals. In addition, the single-payer proposals included other information common in most reform proposals, such as establishing provider standards and enrollment systems, and the establishment of systems that are well-suited to support a single-payer system, such as a drug formulary and electronic records system.

Meaningful policy discussions involving single-payer systems may be aided by a common understanding of its definition. In using the term, I suggest adopting Tuohy's approach in 
defining a single-payer system within a hybrid of subnational systems (characterized by a specified population, service categories, and jurisdiction) because it captures widely what people mean by a single-payer system in the U.S. context while including common characteristics by which systems may differ. For example, state-based systems alongside Medicare would be considered a form of a single-payer system. Subnational systems for specific populations such as Medicare could also be considered a type of single-payer system within the U.S. health care system. Although the most common use of a single-payer plan is for comprehensive benefits, the consideration of catastrophic coverage and high-deductible plans (State of Vermont Agency of Administration, 2014) within the context of one payer suggests that systems falling under a broad single-payer umbrella should not be restricted to comprehensive coverage and little to no cost sharing.

Another reason for this inclusive definition is that existing single-payer systems and proposals vary. Many countries share the aspect of having one payer, but how each national health care system functions is unique. Furthermore, the breadth of recent single-payer proposals shows that most of the proposals are wide-ranging reform plans containing numerous provisions affecting both the financing and delivery systems. These provisions go beyond a simple definition involving the number of payers, and vary across proposals. Thus, this usage of "singlepayer" describes a family of systems - all with the commonality of one payer, but with the scope specified by characteristics that are often contentious and may be debated. ${ }^{3}$

The wide-ranging reform called for in the single-payer proposals is reminiscent of the ACA. Both the ACA and single-payer proposals include coverage provisions to increase health care access and provisions aimed to improve quality while maintaining or reducing costs. Many of the

\footnotetext{
${ }^{3}$ Alternatively, hybrid systems that depart from "pure" single-payer may be better described as "single-pool" or "single-pipe" systems (White, 2009; Fox and Blanchet, 2015).
} 
quality improvement and cost containment strategies that may be applied under either the ACA or a single-payer system are in demonstration stages and their effectiveness is uncertain. For example, accountable care organizations (ACOs) are one way the ACA is trying to control costs, but results have been mixed thus far (Petersen and Muhlestein, 2014). Moreover, the effectiveness of programs also depends on how they are implemented. In addition to uncertain magnitude of effects, the effects may take time to materialize and require initial investments of resources to begin transitioning to a new system. The variation in cost analyses of single-payer proposals (McDonough, 2015) suggests that we do not yet know the impact a single payer would have in the U.S. context.

In this analysis, the coding of the access, quality, and cost provisions in the proposals was based on the intent and plausible impact rather than projected impacts. Single-payer systems are thought to reduce costs through lower administrative costs and bulk purchasing. Having one payer would be a more simple administrative system that has purchasing power, but the extent of cost reductions would likely be greater if the payer structure is coupled with other cost-saving mechanisms. In addition, the coupling with other provisions can also help maintain quality of care. Lower administrative costs may be partially attributed to the efficiency of having a single payer for claims and administration; however, many single-payer systems in other countries also employ electronic claims and payments systems, which also contribute to low administrative costs. Although electronic health record systems have been projected to save billions of dollars through both efficiency and safety (Hillestad et al., 2005), the potential savings and quality improvements depend on widespread and meaningful use of electronic records and operationalization of such electronic systems has proved difficult (DesRoches et al., 2010). Bulk purchasing of drugs and medical supplies and equipment by a single payer that is able to 
negotiate prices is also likely to reduce health care costs. However, some contend that this may be at the expense of medical research and innovation (Calfee, 2001), and we do not know the extent of price reductions that would be possible at a large scale (Cubanski and Neuman, 2016). Similarly, bulk purchasing is likely more effective when coupled with a standard formulary containing the most effective, lowest cost options. An expert board may be charged with the challenging task of determining the medicines on the formulary. However, reductions in prices may be at the expense of medical research and innovation

Single-payer proposals face many of the same political and implementation challenges as the ACA (Pollack, 2015). In both the ACA and the single-payer proposals, the implementation challenges and uncertainties regarding effectiveness of the plans are typical of any large, system wide reform.

For example, one implementation challenge is determining what is included in the benefits package. An expert board typically is charged with deciding what is covered under the statutory plan. Many of the proposals state that all medically necessary care is to be included; however, what is considered medically necessary must be defined. All of the single-payer proposals providing more than catastrophic coverage include some sort of board or committee of medical professionals that decides on the benefit package. For example, the Green Mountain Care Board, an independent committee consisting of five members, in Vermont was responsible for determining the benefits package, health insurance rates, and hospital budgets and major expenditures, as well as evaluating new payment and delivery models. The responsibilities of such boards' may be similar to the functions of the United Kingdom's National Institute for Health and Care Excellence (NICE), which is an independent body that determines the treatments and drugs available through the National Health Service, and to the objectives of the 
ACA's Independent Payment Advisory Board (IPAB), which was established to develop recommendations for reducing Medicare spending if expenditures exceed a target threshold. ${ }^{4}$ These boards are proposed as a way to ensure that effective, appropriate care is provided and reimbursed through the system. However, these type of boards are often perceived as a way to take away patient and provider choice through a form of rationing. The perception of the government making the decisions for patients and providers is particularly unpopular in the U.S. and contrary to the notion of freedom of choice. Patients paying out of pocket up until a catastrophic spending level is reached would be free to choose their health care services; however, features such as what counts towards the deductible, what payment rates are allowed, and what providers are eligible must also be determined. In addition, the catastrophic threshold, the deductible and out-of-pocket maximum levels, and the health care services covered must also be defined. The World Health Organization suggests defining catastrophic health care costs as at least $40 \%$ of household income (discounting income spent on non-health related basic needs), while others have set catastrophic levels as $5 \%$ to $20 \%$ of household income (Xu et al., 2005; Xu et al., 2003). The availability of and eligibility for subsidies for contributions by low-income individuals also must be determined if a safety net for the poor is to be maintained within a catastrophic single-payer system.

With the exception of the proposal for catastrophic coverage, the majority of proposals reviewed had little or no cost sharing for the services included in the single-payer plan. While this ensures that eligible individuals have access to services unfettered by financial constraints, the RAND Health Insurance Experiment showed that people use more health care, both effective

\footnotetext{
${ }^{4}$ IPAB is a controversial component of the ACA. Medicare spending growth has slowed since 2009 and is projected to remain below the threshold that would trigger action by IPAB until 2022 (Medicare Trustees, 2014). The board members have yet to be appointed. Funding for IPAB was greatly reduced in the 2014, and bills to repeal IPAB have been introduced in Congress.
} 
and ineffective care, when care is free (Brook et al., 1984). Thus, without any cost sharing, people tend to over-utilize health care. The rationale for consumer-driven health care with highdeductible plans is that people will be more likely to spend only on necessary care if they are responsible for some of the costs. The other extreme of very high deductibles means that the poor would more likely forego needed health care. Moreover, although individuals on highdeductible plans tend to spend less on health care, they may also reduce their use of preventive care (Beeuwkes Buntin et al., 2011). However, free preventive care could be included under any plan, as is done under the ACA. The Health-Insurance Solution mentions that policymakers could consider covering preventive care and high-value treatments in full in order to avoid reductions in utilization for necessary services.

Although many states have expressed in interest in single-payer systems, state-based systems have additional implementation challenges compared to national health care reform. States must comply with federal requirements and address out-of-state issues. Most state proposals include plans to apply for federal waivers under Section 1332 of the ACA (McDonough, 2014) in order to have a state-based single-payer system finance benefits previously covered through Medicaid and health insurance marketplaces; some also plan to assume responsibility of Medicare benefits. A state-based single-payer plan under a Section 1332 waiver would be required to meet certain requirements, such as providing coverage as comprehensive and affordable as coverage available on health insurance marketplaces; thus, a single-payer system providing catastrophic coverage would not qualify. In addition to waiver requirements, states must address how to reimburse health care services obtained by residents who are temporarily out of state. Conversely, states must also consider the eligibility of non-residents who work in the state, and how these commuters would contribute funds for health care. Furthermore, states cannot regulate self- 
insured employers under the federal Employee Retirement Income Security Act (ERISA), and employers can choose to continue offering private coverage; however, these employers may also be subject to the taxes that finance the single-payer system.

Although availability of coverage for all residents is an important step in increasing access to insurance, challenges in ensuring access to care remain. One challenge is individuals must enroll in the system and most plans require some proof of eligibility, e.g., residence in a state. While some proposals note that social security numbers would not be used for identification and others address language barriers to enrollment, the extent that undocumented individuals would enroll in a government-financed single-payer system is unknown. In addition, access to insurance does not guarantee access to care. For example, following the ACA, there have been concerns about narrow provider networks in insurance plans restricting access to care and lowering the perceived quality of plans (Blumenthal and Collins, 2014; Corlette et al., 2014). Although provider networks would not be an issue in a single-payer system in which patients have free choice of providers, access to care could be restricted if there is inadequate provider supply. Opponents of single-payer systems often point to the waiting times in single-payer systems in other countries (Deber, 2003; Palmisano, 2004; Shaw, 2005; Thomson et al., 2013). The health care system capacity required to accommodate the health care needs of all residents depends partly on provider participation in the program.

A key factor in provider responses in a single-payer system is how provider payments would change. Many of the proposals describe payment options of fee-for-service with rates negotiated between a single-payer health plan board and provider groups, and salaried in institutions with global budgets or capitation. Several proposals also include plans to develop new payment models through demonstration projects. However, it is unclear how providers will respond to 
such changes. Furthermore, health care providers may have the option of participating in a single-payer system and/or a parallel private market.

The availability of private voluntary health insurance could meet a demand for insurance that is not fully provided for by the single-payer plan to improve access for those individuals. The single-payer proposals frequently mention private insurance options, but vary in what types would be allowed. The most common provision regarding voluntary insurance is that substitutive insurance would be banned, but restrictions on other types of voluntary insurance is less common. Complementary and/or supplementary voluntary health insurance is common in other countries (in all European Union member states and Canada) but regulations also vary (Mossialos and Thomson, 2004; Mossialos et al., 2016).

In the U.S., complementary plans are popular with the Medicare population (typically referred to as supplemental coverage in the U.S.). ${ }^{5}$ Although complementary plans make health care more affordable in terms of out-of-pocket expenses, the RAND Health Insurance Experiment found that participants with reduced cost sharing also increased utilization (Brook et al., 1984). Indeed, numerous studies have showed that Medigap enrollees tend to have higher total health expenditures than Medicare beneficiaries not enrolled in Medigap (Atherly, 2002; Golberstein et al., 2013). Studies have estimated that Medigap enrollees have $27-45 \%$ higher Medicare spending that beneficiaries without Medigap coverage (Gruber, 2013; Hogan, 2014). Given that the costs of this increased health care utilization is largely borne by the federal government, policy proposals to reform or eliminate Medigap policies have been explored (Jacobson, Huang and Neuman, 2014).

\footnotetext{
${ }^{5}$ In $2010,86 \%$ of Medicare beneficiaries had some type of supplemental coverage, such as employer-sponsored retiree coverage, Medicare Advantage, or Medigap (Cubanski et al., 2015).
} 
While complementary insurance covers a service gap excluded from the statutory benefit package, supplementary or substitutive insurance creates a parallel risk pool for the same services (Mossialos and Thomson, 2004). The existence of a strong private supplementary insurance market could threaten the operability and access to care within the single-payer system, if inequities such as inadequate provider supply arise in the statutory system.

Supplementary coverage is often for faster access or private care. Allowing individuals who can pay to "jump the queue" for health care is viewed by some as a major consequence due to inequities in access with a two-tiered system for the same services (White, 2009).

Substitutive insurance is less common than supplementary insurance but available in some European countries with statutory multi-payer systems such as Germany (Mossialos and Thomson, 2004). Substitutive insurance may be undesirable because individuals electing to pay for substitutive insurance may still be required to pay mandatory contributions for the statutory plan with identical benefits. Canada is unique among OECD countries in prohibiting substitutive private insurance outright in some provinces. ${ }^{6}$ In Canada, the debate has focused on whether it is constitutional to ban private insurance for medically necessary services when there are long wait times, and whether allowing such private insurance would create a two-tiered system that allows access to the wealthy over the poor (Flood and Haugan, 2010). A two-tiered system can be problematic, for example, for health care provider supply if providers can participate in either the voluntary health insurance market or the single-payer plan. Differences in provider payment schemes could result in health care providers favoring one system over the other, leading to inadequate provider supply in the latter system.

\footnotetext{
${ }^{6}$ Five Canadian provinces prohibit substitutive private coverage for physician and hospital services. In Chaoulli $v$. Quebec in 2005, the Supreme Court of Canada ruled against Quebec's prohibition of substitutive private coverage (Flood and Sullivan, 2005).
} 
There are some limitations to this analysis. The search methodology was intended to capture a range of recent proposals, but was not an exhaustive search of all proposals. In particular, proposals involving a single payer that do not use the term "single payer" may have been excluded. Although I made every effort to include such proposals, they may have been missed during the title and abstract screening stage. The coding of measures relating to access, quality, and cost was a manual process and subject to human error. The assessment was dependent on the detail contained in the proposals. An omission of a provision from a proposal may indicate a lack of detail rather than a deliberate choice in the design of the single-payer system. Furthermore, an omission does not preclude adoption of a measure at a later time. In fact, many proposals indicate that some details would be determined at a later date after additional study.

Regardless of how we pay for health care, whether with insurance premiums or taxes through any number of payers, the goal should be to do it efficiently and deliver quality care. Some features of single-payer plans, such as the potential for reduced administrative costs, are unique to single-payer systems. Also, unlike the ACA, a single-payer system would cause a dramatic change to the health insurance industry, e.g., some single-payer bills include transitional programs for displaced workers of the health insurance industry. When proposals involving a single payer are considered, policymakers ought to clarify the proposed reforms in all health system functions, and not accept or dismiss it solely based on the financing mechanisms. The structure of having one payer alone will not achieve the Triple Aim. As the ACA has begun doing, reform is needed across several areas of the health care system. Many health reform provisions are applicable regardless of the number of payers, but some provisions have natural synergies and may be more effective in a single-payer structure. Further work is needed to explore single-payer alternatives and their potential effects in the U.S. context. 


\section{Summary}

The majority of the proposals with a single payer call for sweeping changes across the full range of health care system functions in pursuit of the Triple Aim - the discussion of singlepayer in recent legislative activity goes beyond simply the number of payers. Common provisions related to access, quality, and cost include comprehensive benefits, patient choice of providers, little or no cost sharing, the role of private insurance, provider guidelines and standards, periodic reviews of the benefits package, electronic medical records and billing systems, a prescription drug formulary, global budgets, an administrative cost threshold, payment reform and studies, and the authority to implement cost containment strategies. Acknowledgement of what is considered single-payer, as well as what must be defined within single-payer systems, can help shape a more nuanced policy debate. Within the structure of a single-payer system, there are many critical characteristics that are variable and define the health care system.

Many states have proposed legislation involving a single payer. Section 1332 of the ACA provides states with an opportunity to design and implement state-based health reform, within the boundaries of equivalent coverage and affordability under the ACA. Given the interest in single-payer systems shown by states, further research is needed to understand what may be achieved by a single-payer system and how it may be implemented in the U.S. We need a better understanding of the potential impact in the U.S. context in order to determine whether there is a viable single-payer solution for the U.S. Exploration of the implementation challenges and the effects of single-payer systems would provide additional evidence to support or oppose singlepayer proposals. For example, research on provider responses to various payment reforms would be useful in determining the impacts on provider supply. Additional studies on the various cost containment strategies would inform single-payer cost estimates for the U.S. Cost analyses 
informed by demonstration projects would improve estimates of the potential effects of singlepayer systems over time and on various stakeholders, and would support policymakers on future health care reform decisions. 


\section{Health Care Coverage and Spending under National Single- Payer Alternatives}

In addition to variation in the definitions of a single-payer system, estimates of the effects of a single payer are driven by several assumptions and vary widely. For example, Friedman (2013) estimated that the Expanded \& Improved Medicare For All Act (H.R. 676, 113th Congress) would reduce federal spending by $\$ 154$ billion in its first year, largely from administrative savings and lower pharmaceutical prices. Estimates from earlier analyses of a single-payer system like the Canadian system ranged from a net savings of $\$ 3$ billion to a net cost of $\$ 31$ billion in 1991 dollars ( $\$ 11$ billion and \$115 billion in 2013 dollars) (General Accounting Office, 1991; Sheils, Young and Rubin, 1992). Estimated savings from three studies of Vermont's single-payer plan also showed substantial variation, ranging from $8-12 \%$ in the short term and $24-25 \%$ in the long term to $1.6 \%$ over 5 years (McDonough, 2015). Most recently, Senator Bernie Sanders' 2016 presidential campaign has claimed that his single-payer plan would save \$6 trillion over the next decade (Sanders, 2016; Friedman, 2016a), while other analyses have estimated the plan to cost $\$ 3$ trillion to over $\$ 10$ trillion in the next ten years (Committee for a Responsible Federal Budget, 2016; Holahan et al., 2016; Thorpe, 2016). The variation across estimated effects can be attributed to differences in assumptions and methodology (Friedman, 2016b; McDonough, 2015; Aaron, 2003; Sheils, Young and Rubin, 1992).

Some of the assumed effects have a strong evidence base, while others are not supported by empirical evidence and are based on more uncertain assumptions. Projections of increased utilization of medical care due to enhanced insurance coverage are typically based on the 
elasticity of the demand for health care services with respect to cost sharing. Although several decades old, the demand curve estimated in the RAND Health Insurance Experiment (Manning et al., 1987) is still widely accepted as a gold standard (Aron-Dine, Einav and Finkelstein, 2013; Zweifel and Manning, 2000). In contrast, estimates of administrative savings are often based on comparisons of administrative costs in the U.S. and other countries (Himmelstein et al., 2014). In addition to the uncertainty of whether the U.S. would be able to reduce administrative costs to the levels of other countries, it is unclear how long it would take to achieve such savings. Similarly, estimates of drug prices under a single-payer plan, which allows for negotiated prices and bulk purchases, are typically based on either prices in other countries or prices received by public programs in the U.S. (Angrisano et al., 2007; Sheils and Haught, 2001). There are uncertainties in the extent and timeframe that price reductions could be achieved in the U.S. and potential unintended consequences.

In this chapter, I describe the use of microsimulation and parameters from the literature to estimate health care spending under national single-payer health care alternatives. The objectives were to estimate coverage and health care spending and to make explicit the assumed savings and costs. Given the varied certainty in the evidence base on the effects of single-payer systems, I estimated the effects on spending in two stages. First, I estimated coverage and spending due to changes in utilization of health care services under single-payer plans and changes in payment due to financing mechanisms. Next, I identified ranges of possible effects from the literature and used these parameters to estimate the "other savings and costs," including administrative savings, reductions in drug and provider payments, and implementation costs. Clearly separating and delineating the features of a single payer that lead to savings or costs contributes to a more nuanced discussion about the fiscal effects of health care reform involving a single payer. 


\section{Policy Scenarios}

I analyzed two sets of scenarios - one labeled comprehensive and the other catastrophic involving a national single payer providing universal, tax-financed coverage relative to what would occur under the ACA in 2017. The scenarios are shown in Table 3.1.

Table 3.1. Single-Payer Scenarios

\begin{tabular}{|c|c|c|c|c|c|c|}
\hline & \multicolumn{3}{|c|}{ Comprehensive Single Payer } & \multicolumn{3}{|c|}{ Catastrophic Single Payer } \\
\hline & Comp-Base & Comp-Low AV & Comp-High Tax & Cata-Base & Cata-Priv Ins & Cata-No Excl \\
\hline Proposal & \multicolumn{3}{|c|}{$\begin{array}{l}\text { Based on the American Health Security Act (S. 1782, } \\
\text { 113th Congress) }\end{array}$} & \multicolumn{3}{|c|}{$\begin{array}{l}\text { Based on the Health-Insurance Solution } \\
\text { (Hagopian and Goldman, 2012) }\end{array}$} \\
\hline Eligibility & \multicolumn{3}{|c|}{ Available to all U.S. citizens and legal residents } & \multicolumn{3}{|c|}{$\begin{array}{l}\text { Available to all U.S. citizens and legal residents } \\
\text { not covered by Medicare and Medicaid } \\
\text { (Medicare and Medicaid programs continued) }\end{array}$} \\
\hline \multirow[b]{3}{*}{$\begin{array}{l}\text { Plan } \\
\text { Design }\end{array}$} & \multicolumn{3}{|c|}{ Uniform coverage with limited cost sharing } & \multicolumn{3}{|c|}{ Income-dependent coverage } \\
\hline & $\begin{array}{l}98 \% \text { actuarial } \\
\text { value }\end{array}$ & $\begin{array}{l}78 \% \text { actuarial } \\
\text { value }\end{array}$ & $\begin{array}{l}98 \% \text { actuarial } \\
\text { value }\end{array}$ & $\begin{array}{l}\text { Deductible } \\
\text { Coinsurance } \\
\text { OOP maxim }\end{array}$ & $\begin{array}{l}\% \text { of surplus incc } \\
5 \% \\
=14.5 \% \text { of surp }\end{array}$ & income \\
\hline & \multicolumn{3}{|c|}{$\begin{array}{l}\text { Private insurance duplicating single-payer coverage } \\
\text { prohibited }\end{array}$} & $\begin{array}{l}\text { Private } \\
\text { insurance } \\
\text { prohibited }\end{array}$ & $\begin{array}{l}\text { Private } \\
\text { insurance not } \\
\text { restricted, } \\
\text { ESI tax } \\
\text { exclusion } \\
\text { continued }\end{array}$ & $\begin{array}{l}\text { Private } \\
\text { insurance not } \\
\text { restricted, } \\
\text { ESI tax } \\
\text { exclusion } \\
\text { eliminated }\end{array}$ \\
\hline $\begin{array}{l}\text { Financing } \\
\text { Design }\end{array}$ & \multicolumn{2}{|c|}{$\begin{array}{l}\text { Graduated income tax from } \\
2.2 \% \text { to } 5.2 \% \text {, plus } 5.4 \% \\
\text { surcharge for high earners } \\
6.7 \% \text { payroll tax paid by } \\
\text { employers } \\
0.02 \% \text { securities transaction tax }\end{array}$} & $\begin{array}{l}17 \% \text { income tax } \\
6.7 \% \text { payroll tax } \\
\text { paid by employers } \\
0.02 \% \text { securities } \\
\text { transaction tax }\end{array}$ & \multicolumn{3}{|c|}{$\begin{array}{l}\text { Per capita tax for the eligible population: } \\
\$ 0 \text { if }<100 \% \mathrm{FPL} \\
\$ 0 \text { to } \$ 3,350 \text { on a linear scale if } 100-300 \% \mathrm{FPL} \\
\$ 3,350 \text { if }>300 \% \mathrm{FPL}\end{array}$} \\
\hline
\end{tabular}

ESI=employer-sponsored insurance, OOP=out-of-pocket, AGI=adjusted gross income, FPL=federal poverty level

NOTES: Health insurance plans can be designed in different ways and have the same AV. I modeled the $98 \%$ AV plan with a zero deductible, $2.5 \%$ coinsurance, and $\$ 2,000$ OOP maximum. I modeled the $78 \%$ AV plan with a $\$ 1,175$ deductible, $20 \%$ coinsurance, and \$6,500 OOP maximum. In the catastrophic scenarios, surplus income was defined as the difference between AGI and FPL. The AV of the base catastrophic plan (Cata-Base) was $75 \%$.

The comprehensive scenarios were based on the American Health Security Act (S. 1782, 113th Congress; H.R. 1200, 114th Congress), last sponsored by Senator Bernie Sanders (I-VT) in 2013 and Representative Jim McDermott (D-WA) in 2015. The bill was introduced in both the Senate and the House of Representative with no cosponsors. ${ }^{7}$ The American Health Security Act

\footnotetext{
${ }^{7}$ Senator Sanders' 2016 presidential campaign includes a Medicare for All plan that is similar the federal bill he previously sponsored (Sanders, 2016).
} 
was selected as the basis of the comprehensive scenarios because its financing plan is more detailed than other similar proposals, such as the Expanded \& Improved Medicare For All Act. An alternative comprehensive scenario was based the Expanded \& Improved Medicare For All Act (H.R. 676, 114th Congress), last sponsored by Representative John Conyers (D-MI) in 2015 with 60 cosponsors. Both of these federal bills have been introduced in several previous legislative sessions, with H.R. 1200 first introduced in 1993 by Representative McDermott and H.R. 676 first introduced in 2011 by Representative Conyers. Both would provide coverage for comprehensive benefits without cost sharing, finance the plan through a variety of taxes, and prohibit substitutive private insurance that duplicates coverage provided by the single-payer plan. Although the American Health Security Act does not specify whether supplementary or complementary private insurance would restricted, the role of voluntary private insurance is more limited when the statutory plan provides comprehensive coverage of services at no out-ofpocket costs to individuals.

The comprehensive scenarios provide all citizens and legal residents with uniform health insurance coverage for a full range of benefits including hospital services, professional services, prescription drugs, and other medically necessary services. The American Health Security Act specifies no cost sharing for benefits covered by the single-payer plan. The plan would be financed by a graduated income tax from $2.2 \%$ on taxable income less than $\$ 200,000$ ( $\$ 250,000$ for joint returns) to $5.2 \%$ on taxable income greater than $\$ 600,000$ in 2014 dollars, a $5.4 \%$ surcharge on modified adjusted gross income exceeding $\$ 1$ million, a $6.7 \%$ payroll tax paid by employers, and a $0.02 \%$ securities transaction tax. The base comprehensive scenario (CompBase) was designed to reflect the federal bill as written, with $98 \%$ actuarial value (AV) and the above tax rates. A 98\% AV plan means that, on average, individuals would pay out-of-pocket for 
$2 \%$ of health care expenditures for services not covered by the single-payer plan. In the low-AV comprehensive scenario (Comp-Low AV), I adjusted the plan generosity downward to maintain federal health care expenditures at the tax rates specified in the bill. The high-tax comprehensive scenario (Comp-High Tax) is an illustrative scenario with the single-payer income tax rate adjusted upward to match federal expenditures under the ACA while still providing $98 \% \mathrm{AV}$.

The catastrophic scenarios were based on the Health-Insurance Solution (Hagopian and Goldman, 2012). The objective of this proposal is to protect individuals and families against large financial losses by providing catastrophic coverage. Under this proposal, the Medicare and Medicaid programs continue and all other citizens and legal residents would be provided with income-dependent coverage. The deductible would be set at $10 \%$ of a family's surplus income, defined as adjusted gross income minus the federal poverty level (FPL), and the coinsurance would be $5 \%$ until the catastrophic threshold of 10 times the deductible was met. I adjusted the per capita tax rate to match expected medical expenditures.

The Health-Insurance Solution does not restrict private insurance options alongside the catastrophic plan, and suggests the elimination of the tax exclusion for employer-sponsored insurance (ESI) while acknowledging the political barriers. I simulated scenarios prohibiting private insurance (Cata-Base) and not restricting private insurance with and without the tax exclusion (Cata-Priv Ins and Cata-No Excl).

In all of the single-payer scenarios, there are effects on overall health care expenditures and distributional effects across income due to changes in plan generosity and financing. There are also uncertainties in how health care expenditures may be affected by other characteristics of a single-payer system. Key uncertainties include changes in administrative costs, drug and provider payment rates, and implementation costs. 


\section{Methods}

In this analysis, I used a combination of methods to assess insurance choice, utilization of health care services, financing, and savings and costs associated with a single payer. The financing streams that I modeled are shown in the conceptual framework in Figure 3.1. Households make direct payments in the form of premiums and out-of-pocket payments, and indirect payments in the form of taxes to the federal and state governments, health insurance exchanges (also known as marketplaces), and employers. Funds flow from the payers/sponsors to insurance plans, which pay for health care expenditures on behalf of its enrollees.

In Figure 3.1, the financing streams modeled in the microsimulation are shown in blue. I modeled two main individual behaviors: what insurance to enroll in and the amount of health care services to utilize. An individual or household's choice of insurance depends on the availability of private insurance options and their eligibility for public insurance programs. ${ }^{8}$ The utilization of health care services and subsequent expenditures depends on an individual's expected utilization under free care and the cost sharing of their insurance plan. In addition, I modeled firms' decision to offer insurance, firm spending on insurance, and the trade-off between firm spending on wages and health benefits.

Payments that are exogenous to the above behaviors, such as public premiums, are shown in red. Income, payroll, single-payer, and state taxes are also shown in red; the tax rates are exogenous but the tax revenues vary with wages, which depend on firm decisions regarding employer-sponsored insurance (ESI). Government inflows to health plans and through other payers (exchange subsidies and the value of the ESI tax exclusion) are shown in green.

\footnotetext{
${ }^{8}$ In the comprehensive scenarios, individuals do not have a choice of insurance as all legal residents would be enrolled in the single-payer plan.
} 
Figure 3.1. Conceptual Framework of Health Care Financing

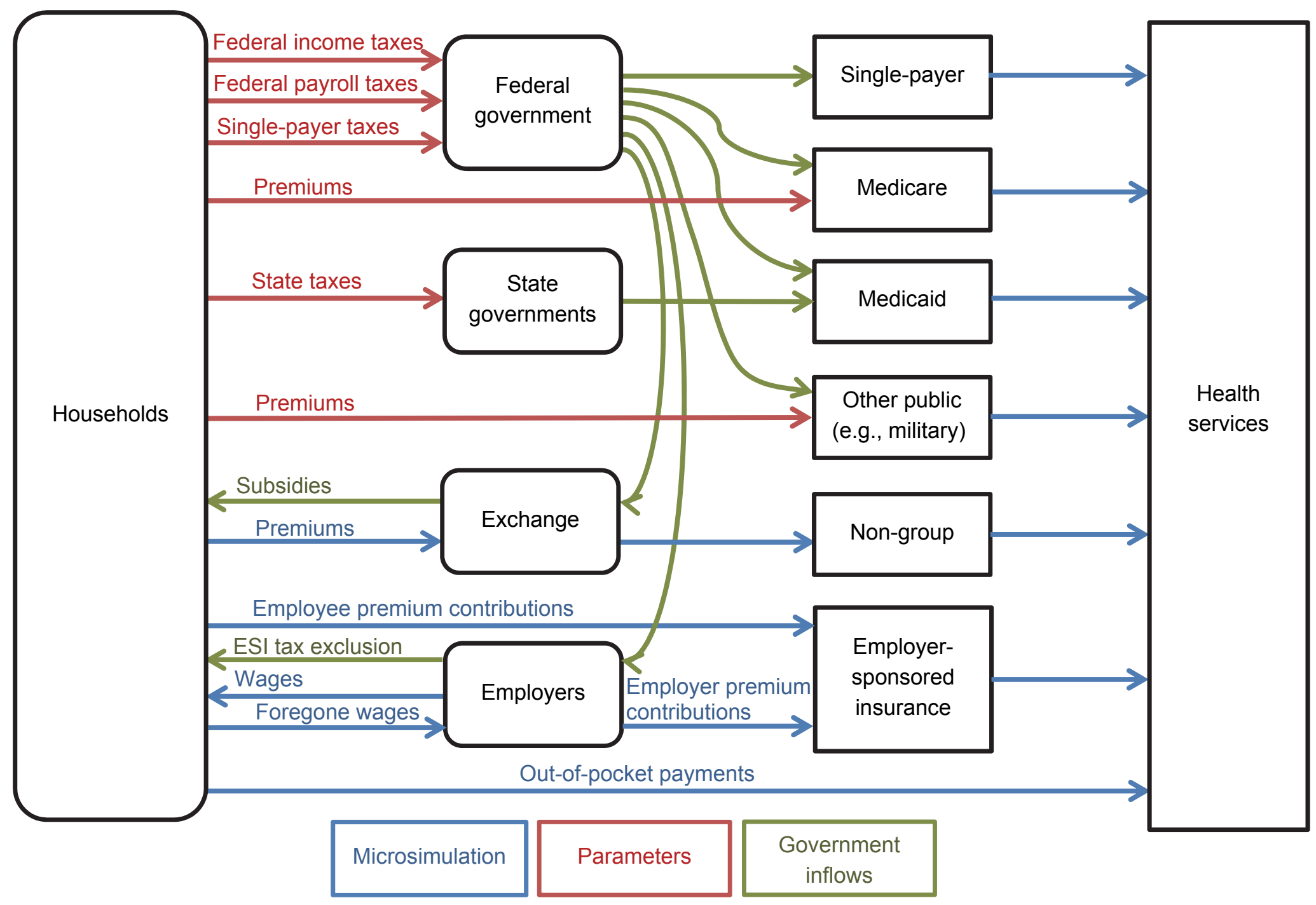

SOURCE: Adapted from Eibner et al. (2015) 


\section{Population and Data Sources}

I used RAND's Comprehensive Assessment of Reform Efforts (COMPARE) model to estimate coverage and spending under single-payer scenarios. COMPARE is a microsimulation model based on economic theory that assesses changes in health policy. A full description of the model has been published elsewhere (Cordova et al., 2013) and is described briefly below. The primary data sources used in COMPARE are the Survey of Income and Program Participation (SIPP), the Medical Expenditures Panel Survey - Household Component (MEPS-HC), and the Kaiser Family Foundation (KFF)/Health Research Educational Trust (HRET) Employee Health Benefits Survey.

The synthetic population comes from the 2008 SIPP wave 6 collected from May 2010 to August 2010. SIPP is a nationally representative survey of households conducted by the U.S. Census Bureau and includes demographic, income, health insurance status, and employment variables. Each individual in the SIPP was assigned medical expenditures from a similar individual in the 2010 and 2011 MEPS-HC based on age, sex, health status, income, and insurance status. To correct the underrepresentation of high-spending individuals on the right tail of the expenditures distribution, the top one percent of medical expenditures was adjusted to reflect expenditures in the 1997-1999 Society of Actuaries (SOA) large claims data collected in the Medical Large Claims Experience Study. Medical expenditures were aligned to the 2010 National Health Expenditures Accounts (NHEA) Personal Health Care expenditures (Bernard, Selden and Pylypchuk, 2015), and inflated using NHEA projected per capita growth rates.

Employer data are from the $2009 \mathrm{KFF} / \mathrm{HRET}$ Employee Health Benefits Survey, a nationally representative sample of employers that includes employer characteristics, the number and type of health insurance plans offered to employees, costs of coverage, employee contributions, and 
cost sharing information. Workers in the SIPP were matched to the KFF/HRET employers based on firm size, whether the firm offers health insurance, industry, and region.

\section{Behaviors in the Microsimulation}

In COMPARE, individual and firm decision-making are based on the costs and benefits of the available options, summarized as the utility of each option. The utility of health insurance coverage depends on the value of health spending, premiums, expected out-of-pocket (OOP) spending, and risk aversion:

$$
\begin{aligned}
& U_{i}=u\left(H_{i}\right)-p_{i}-E\left(o_{i}\right)-1 / 2 r \operatorname{Var}\left(o_{i}\right) \\
& \text { where } U_{i}=\text { utility for individual i } \\
& \begin{array}{ll}
u\left(H_{i}\right) & =\text { value of health care spending } \\
p_{i} & =\text { health insurance premium } \\
E\left(o_{i}\right) & =\text { expected value of out-of-pocket spending } \\
r & =\text { Pratt risk aversion coefficient } \\
\operatorname{Var}\left(o_{i}\right) & =\text { variance of out-of-pocket spending }
\end{array}
\end{aligned}
$$

Firm utility depends on aggregate worker utility and the cost of offering insurance:

$$
\begin{aligned}
& \begin{array}{cl}
U_{\alpha}=\lambda V_{\alpha}-C_{\alpha} & \\
\text { where } U_{\alpha} & =\text { firm utility for insurance offer option } \alpha \\
\lambda & =\text { firm's weight on worker utility } \\
V_{\alpha} & =\text { aggregate worker utility with offer } \alpha \\
C_{\alpha} & =\text { cost of offer } \alpha \text { to the firm }
\end{array}
\end{aligned}
$$

The simulated changes in medical expenditures relative to the cost sharing of each plan are calculated using the demand curve from the RAND Health Insurance Experiment (Newhouse and The Insurance Experiment Group, 1993). With decreased cost sharing, individuals are expected to utilize more health care services, contributing to higher expenditures.

Economic theory suggests that employer-provided health benefits are traded-off with wages as part of total compensation (Leibowitz, 1983; Pauly, 1988; Pauly, 1999; Gruber, 2000). I 
calculated a wage pass back as the difference between employer spending on premiums in the ACA and employer spending on premiums or single-payer taxes in each scenario. I assigned the wage pass back to workers proportionally to their income in each firm. ${ }^{9}$ I assumed that additional income tax and Medicare payroll tax revenues generated from the wage pass back would be used to support the single-payer system (or Medicare in the catastrophic scenarios).

\section{Comprehensive Scenario Behaviors}

In the comprehensive scenarios, I assumed that all eligible citizens and legal residents would be automatically enrolled in the generous, comprehensive plan. ${ }^{10}$ I assumed that undocumented immigrants would not be covered by the single-payer plan. ${ }^{11}$ Health insurance duplicating benefits covered by the single-payer plan was prohibited. Thus, as ESI was not a primary insurance option, I did not model firm choice in these scenarios. As all citizens and legal residents would be automatically enrolled in a generous comprehensive that would serve as their primary coverage, I also did not model individual choice of insurance in the comprehensive scenarios.

I assumed $98 \% \mathrm{AV}$ in the base and high-tax comprehensive scenarios. ${ }^{12}$ The plan design in the low-AV comprehensive scenario reflects $78 \% \mathrm{AV}$, which is more similar the current Medicare program that has an average benefit value of $80 \%$ (McArdle, 2012).

\footnotetext{
${ }^{9}$ As a sensitivity analysis, I conducted a second wage pass back assignment by assigning wage increases by the predicted probability that a worker receives an ESI offer, which did not substantively change the results.

${ }^{10}$ Not all who are eligible for a benefit will enroll; however, experience from the Medicare program suggests that enrollment can be high. In 2015, there were 47.8 million residents aged 65 years and older, and Medicare Part A and/or B enrollment totaled 46.4 million aged beneficiaries (Centers for Medicare \& Medicaid Services, 2016b).

${ }^{11}$ The coverage of undocumented immigrants varies across single-payer proposals, and proposals often do not specify whether undocumented immigrants would be covered.

${ }^{12}$ Although the American Health Security Act specifies no cost sharing for covered benefits, some health care services will not be covered by the plan and would require out-of-pocket payments. A 98\% AV plan means that individuals would pay out-of-pocket for $2 \%$ of health care costs on average.
} 


\section{Catastrophic Scenario Behaviors}

In the catastrophic scenarios, I also assumed that all eligible citizens and legal residents would be automatically enrolled in the catastrophic plan. In scenarios with private insurance coverage allowed alongside a catastrophic plan, individuals had the option of enrolling in ESI or non-group plans to cover expenses below their catastrophic deductible. The tax exclusion for ESI was maintained in one scenario and eliminated in the other scenario. A firm's decision to offer ESI and how much to spend on premium contributions on behalf of their employees are influenced by the tax treatment of ESI. Without the ESI tax exclusion, a firm may choose to still offer ESI to take advantage of pooling, negotiation, and administration within a large group. I used published elasticities to adjust firms' decision to offer ESI and firm spending based on the tax price (Gruber and Lettau, 2004); see Appendix B for details. In the non-group market, I assumed ACA regulations such as guaranteed issue and mandatory community rating would continue.

I assumed that private insurance options (ESI and non-group) would be available as fullycustomized plans based on family income. The private plan would cover expenditures below the income-dependent catastrophic deductible without a maximum out-of-pocket limit. For low- and middle-income individuals, private coverage may serve as a wraparound plan. For high-income individuals, private coverage may be their primary coverage as it is less likely for them to reach their catastrophic deductible. Private premiums were calculated by assuming premiums were proportional to income and age (see Appendix B).

\section{Tax Financing}

Public health care programs are financed by a variety of taxes. I assumed existing sources of federal government revenues for health care programs would continue to be collected and would be allocated to finance the single-payer plan. These sources include personal income taxes, 
payroll taxes, and other taxes currently used to fund health care programs. In scenarios with Medicaid, I assumed that a portion of state income tax revenues would be used to fund Medicaid. In addition to existing sources of tax revenue, I modeled taxes dedicated to the single-payer program: an income tax, payroll tax paid by employers, and securities transaction tax in the comprehensive scenarios and a flat per capita tax with subsidies for lower-income households in the catastrophic scenarios.

Federal and state income taxes were calculated using National Bureau of Economic Research's (NBER) TAXSIM model (National Bureau of Economic Research, 2013). The model contains federal and state income tax returns from the Internal Revenue Service (IRS) and a tax calculator. Income variables from the 2008 SIPP wave 6 core file were used to prepare the inputs to TAXSIM (see Appendix B for details). I separately calculated the Medicare Net Investment Income Tax (NIIT), which started in 2013, based on dividend, property, and interest income and federal adjusted gross income. The NIIT is $3.8 \%$ of net investment income if modified adjusted gross income exceeds the following thresholds: $\$ 125,000$ if married and filing separately, $\$ 200,000$ if single, and $\$ 250,000$ if married and filing jointly (U.S. Internal Revenue Service, 2015b). To match national benchmarks published by the Congressional Budget Office (CBO), federal income taxes were adjusted to CBO estimates (Congressional Budget Office, 2015a) by allocating the difference according to the distribution of taxes by income (U.S. Internal Revenue Service, 2013).

To estimate the share of federal income taxes used to fund health care under current policies, I assumed the share was proportional to the share of federal outlays on health care programs (see Appendix B for details). Based on projections of outlays in 2017, I estimated that $34 \%$ of federal income taxes would be used to support health care. 
In the ACA and catastrophic scenarios, I estimated the share of state income taxes going to support health care as the Medicaid share of general fund expenditures for each state (Kaiser Family Foundation, 2013). In the comprehensive scenarios in which the Medicaid program would be merged into the single-payer program, I assumed that state income tax revenue and other state funds used for health care programs would be reallocated elsewhere.

I calculated the Additional Medicare Tax that started in 2013 as part of payroll tax payments. The Additional Medicare Tax is $0.9 \%$ of wages exceeding $\$ 125,000$ if married and filing separately, \$200,000 if single, and \$250,000 if married and filing jointly (U.S. Internal Revenue Service, 2015a).

I assumed that other existing revenue from taxes such as corporate income taxes, excise taxes, and estate and gift taxes that may be used to support health care programs under the ACA would continue in the single-payer scenarios. Under the ACA, other federal taxes were assumed to fund the costs beyond the estimated revenue from income and payroll taxes and premiums for public programs. In scenarios with Medicaid, other state taxes such as sales taxes were assumed to fund the state portions of Medicaid expenditures not funded by state income tax revenue.

The Social Security Administration's Office of the Chief Actuary estimated that, of 7.0 million undocumented workers, 3.1 million (44\%) worked and paid Social Security payroll taxes in 2010 (Goss et al., 2013). As a proxy, I assumed only the undocumented immigrants assigned to large firms (100 or more workers), which was $48 \%$ of undocumented workers, paid income and payroll taxes.

The single-payer income tax in the comprehensive scenarios is based on the tax schedule proposed in the American Health Security Act. The tax rate increases from $2.2 \%$ to $5.2 \%$ of 
taxable income depending on income (see Appendix B for details). The $6.7 \%$ single-payer payroll tax is paid by employers; as aforementioned, the incidence is assumed to be on workers.

The single-payer securities transaction tax was based on the fair market value of the security. I assumed the incidence would fall on end users. I calculated the total securities transaction tax revenue using the 2013 transaction volumes of equities, options, futures deliveries (U.S. Securities and Exchange Commission, 2015), and bonds (Securities Industry and Financial Markets Association, 2015), and a 25\% assumed reduction in trading volume due to the imposition of the tax (see Appendix B for details). I assigned the tax uniformly to individuals who reported a capital gain or loss in the SIPP wave 5 topical module.

\section{Other Savings and Costs}

In addition to the effects of changes in utilization due to cost sharing and financing, estimates of other savings and costs associated with a single payer were gathered from the literature. The following keywords were used in combination to search PubMed, EconLit, Web of Science, Scopus, and Embase:

single payer, national health insurance, single pool, single pipe, "Single-Payer System"[Mesh], savings, cost, "Costs and Cost Analysis"[Mesh], administrat", "Health Services Administration"[Mesh], pharmaceutical price, negotiat* power, bulk purchasing, payment rate, provider payment, provider reimbursement, hospital reimbursement, "Insurance, Health, Reimbursement"[Mesh], implementation cost, "Health Plan Implementation"[Mesh], start-up cost, training, displaced worker, electronic systems, electronic health record, electronic medical record, electronic billing, electronic claims, "Medical Records Systems, Computerized"[Mesh].

The searches were limited to publications from no earlier than 1990 as the term single-payer did not come into use until the early 1990s (Tuohy, 2009). Publications not in English and duplicate records were excluded. After the exclusions, 5,962 articles were identified.

The resulting publications were first screened by title; publications on specific diseases and conditions, and developing countries were excluded. The title screen resulted in 296 articles. 
Next, the titles were organized into categories of savings and costs. Abstracts were screened for savings and cost estimates or relevant parameters. I extracted 73 savings and cost parameters from 18 sources as part of full-text review and reference mining.

I assumed that other savings and costs would accrue to the federal government. The sum of the savings in administrative costs, drug prices, and provider payments and the new costs were subtracted from the national and federal expenditures.

\section{Results}

\section{Effects of Cost Sharing and Financing on Coverage and Spending}

The predicted primary insurance coverage under each scenario is shown in Table 3.2. In the comprehensive scenarios, all citizens and legal residents were covered by the single-payer plan while the remaining 11 million uninsured are undocumented immigrants. In the base catastrophic scenario, Medicare and Medicaid coverage continued for eligible individuals; all other citizens and legal residents ( $63 \%$ of the population) had the single-payer plan for their primary coverage as private insurance options were prohibited. In the catastrophic scenarios allowing private coverage, $55 \%$ and $54 \%$ of the population were not covered by Medicare and Medicaid and enrolled in private insurance; such individuals would also be covered by the catastrophic singlepayer plan. Without the tax advantage for ESI, fewer individuals enrolled in ESI but most of these individuals instead enrolled in non-group plans. The remaining uninsured in the two catastrophic scenarios allowing private coverage ( 5 and 7 million, respectively) are undocumented immigrants who were not enrolled in private insurance and were not eligible for the single-payer coverage. 
Table 3.2. Estimated Insurance Coverage in 2017

\begin{tabular}{lrrrrr}
\hline Primary insurance & \multicolumn{5}{c}{ Population in millions (share, \%) } \\
& ACA & Comp & Cata-Base & Cata-Priv Ins & Cata-No Excl \\
\hline ESI & $155(48 \%)$ & - & - & $141(44 \%)$ & $119(37 \%)$ \\
Non-group/Exchange & $25(8 \%)$ & - & - & $35(11 \%)$ & $54(17 \%)$ \\
Medicaid & $58(18 \%)$ & - & $56(17 \%)$ & $56(17 \%)$ & $56(17 \%)$ \\
Medicare & $52(16 \%)$ & - & $52(16 \%)$ & $52(16 \%)$ & $52(16 \%)$ \\
Military & $5(1 \%)$ & - & - & - & - \\
Single-payer & $-311(96 \%)$ & $203(63 \%)$ & $33(10 \%)$ & $34(11 \%)$ \\
Uninsured & $27(9 \%)$ & $11(4 \%)$ & $11(4 \%)$ & $5(2 \%)$ & $7(2 \%)$ \\
\hline $\begin{array}{l}\text { NOTE: In the catastrophic scenario, citizens and legal residents with private coverage (ESI or non-group) and single- } \\
\text { payer coverage are listed as having private insurance as their primary coverage. }\end{array}$
\end{tabular}

Figure 3.2 shows estimated national health care expenditures resulting from changes in utilization and prior to other savings and costs. The heights of the bars represent MEPS-aligned NHEA Personal Health Care expenditures plus administrative costs. Before other savings and cost assumptions, the base and high-tax comprehensive scenarios increased national expenditures by $\$ 435$ billion relative to the ACA, due to low cost sharing and coverage of all legal residents. The alternative comprehensive scenario based on the Medicare For All Act resulted in similar expenditures (Appendix C). In the low-AV comprehensive scenario, the reduction of the plan generosity to $78 \% \mathrm{AV}$ reduced national expenditures by $\$ 179$ billion relative to the ACA. The base catastrophic scenario reduced national health care expenditures by $\$ 211$ billion relative to the ACA, while the catastrophic scenarios allowing private coverage reduced national spending by $\$ 107-109$ billion. 
Figure 3.2. National Health Care Spending by Source of Revenue in 2017

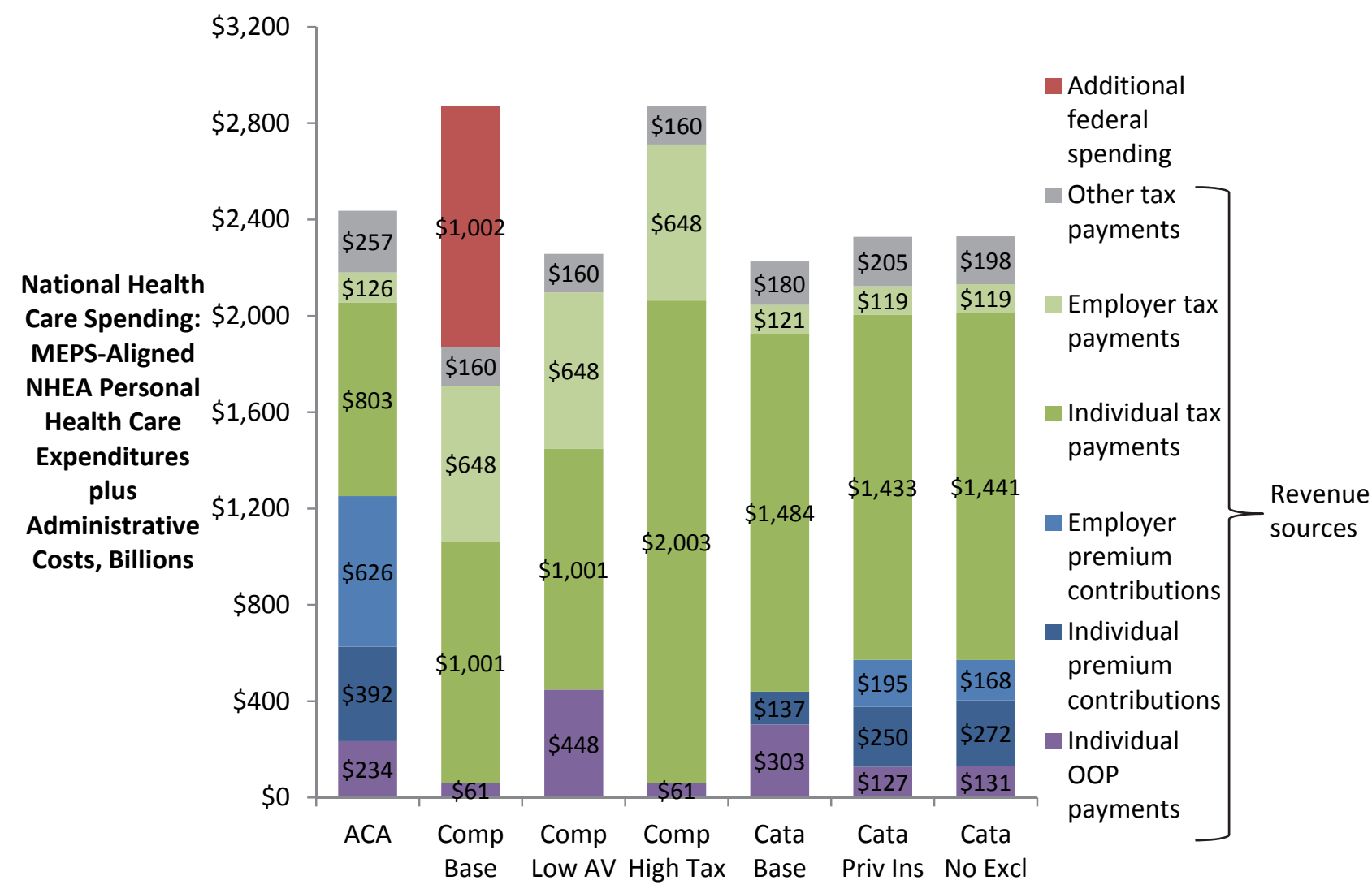

NOTES: The expenditures are the MEPS-aligned NHEA Personal Health Care Expenditures plus administrative costs. The effect of cost sharing on spending is included, but other savings and costs associated with single-payer systems are not included here. Sources of revenue in the form of out-of-pocket payments, premium contributions, and tax payments are overlaid on spending. Other tax payments include taxes such as corporate income taxes, excise taxes, estate and gift taxes, and state sales taxes. The additional federal spending represents the gap between projected spending and revenue sources.

The sum of OOP payments, premium contributions, and tax payments (all categories except 'additional federal spending') represent total revenue allocated to fund health care (Figure 3.2). Total revenue under the ACA was $\$ 2.4$ trillion, from average payments of $\$ 7,560$ per capita. Total revenue was lower in the base and low-AV comprehensive scenarios, with per capita payments reduced to $\$ 5,800$ and $\$ 7,000$, respectively; per capita payments were increased to $\$ 8,910$ in the high-tax comprehensive scenario. In the catastrophic scenarios, per capita payments ranged from $\$ 6,900$ to $\$ 7,230$. In all of the single-payer scenarios, health care 
financing was shifted away from premiums, previously paid by individuals directly and through employer contributions, towards a variety of single-payer taxes.

The 'additional federal spending' category represents the discrepancy between estimated spending and revenue in each scenario (Figure 3.2). In other words, the additional federal spending is the net cost to the federal government (either as deficit spending or additional revenue needed). The base comprehensive scenario is notably underfinanced with $\$ 1$ trillion of additional federal spending needed. However, these results include only the effect of the plan generosity on health care utilization and the effect of the financing design, and are prior to other savings or costs assumptions. Although federal spending increased, spending on premiums by individuals was reduced by $\$ 1$ trillion; in other words, the increase in funds flowing through the federal government replaced $\$ 918$ billion in private premiums and $\$ 101$ billion in premiums for public programs.

Federal spending on health care programs is further subdivided in Table 3.3. Relative to the ACA, the base comprehensive scenario increased federal expenditures by $\$ 1$ trillion (before other savings and cost assumptions). In low-AV and high-tax comprehensive scenarios, federal spending matches spending under the ACA, as the plan generosity was reduced to $78 \% \mathrm{AV}$ in low-AV scenario and the single-payer income tax rate was raised to $17 \%$ in order to finance the 98\% AV plan in high-tax scenario. The base catastrophic scenario reduced federal expenditures by $\$ 40$ billion (and reduced private insurance spending by $\$ 880$ billion) relative to the ACA. Allowing private insurance options in catastrophic scenarios reduced federal expenditures by \$23-29 billion (and reduced private insurance spending by \$573-578 billion). 
Table 3.3. Federal Health Care Spending in 2017

\begin{tabular}{lrrrrrrr}
\hline & ACA & $\begin{array}{r}\text { Comp } \\
\text { Base }\end{array}$ & $\begin{array}{r}\text { Comp } \\
\text { Low AV }\end{array}$ High Tax & $\begin{array}{r}\text { Comp } \\
\text { Base }\end{array}$ & $\begin{array}{r}\text { Cata } \\
\text { Priv Ins }\end{array}$ & $\begin{array}{r}\text { Cata } \\
\text { No Excl }\end{array}$ \\
\hline Spending (\$ billions) & & & & & & & \\
Medicare & 707 & - & - & - & 707 & 707 & 707 \\
Medicaid & 203 & - & - & - & 193 & 193 & 193 \\
Military & 42 & - & - & - & - & - & - \\
Exchange & 72 & - & - & - & - & - & - \\
Single-payer & - & 2,457 & 1,570 & 2,457 & 679 & 665 & 664 \\
Uninsured & 70 & 35 & 35 & 35 & 35 & 21 & 26 \\
Government administration & 39 & 319 & 204 & 319 & 127 & 125 & 125 \\
& 1,133 & 2,811 & 1,809 & 2,811 & 1,740 & 1,711 & 1,714 \\
Revenue (\$ billions) & & & & & & & \\
Income tax supporting health care & 594 & 604 & 604 & 604 & 717 & 680 & 686 \\
Medicare payroll tax & 261 & 266 & 266 & 266 & 279 & 275 & 275 \\
Penalty payments & 17 & - & - & - & - & - & - \\
Single-payer taxes & - & 778 & 778 & 1,780 & 524 & 520 & 521 \\
Other taxes supporting health care & 160 & 160 & 160 & 160 & 160 & 160 & 160 \\
Medicare premiums & 100 & - & - & - & 100 & 100 & 100 \\
TRICARE premiums & 1 & - & - & - & - & - & - \\
& 1,133 & 1,810 & 1,810 & 2,811 & 1,781 & 1,735 & 1,743
\end{tabular}

Net federal spending relative to ACA

1,002

0

$-40$

$-23$

$-29$

NOTES: The effect of cost sharing on spending is included, but other savings and costs associated with single-payer systems are not included here. Other tax payments include taxes such as corporate income taxes, excise taxes, and estate and gift taxes.

Figure 3.3 shows average household spending on health care as a share of income by income level. The numerator is household spending on health care, which consists of premium contributions, OOP payments, and taxes supporting health care. The income denominator includes household income and employer premium contributions. Health care payments in the single-payer scenarios were generally more progressive by income relative to the ACA. In the base comprehensive scenario, households $<1000 \%$ FPL paid $28-84 \%$ of what they paid under the ACA and households $\geq 1000 \%$ FPL paid $23 \%$ more on average. Household income at $1000 \%$ FPL was estimated to be $\$ 124,086$ for a single individual and $\$ 253,595$ for a family of four in 
Figure 3.3. Average Household Spending on Health Care in 2017
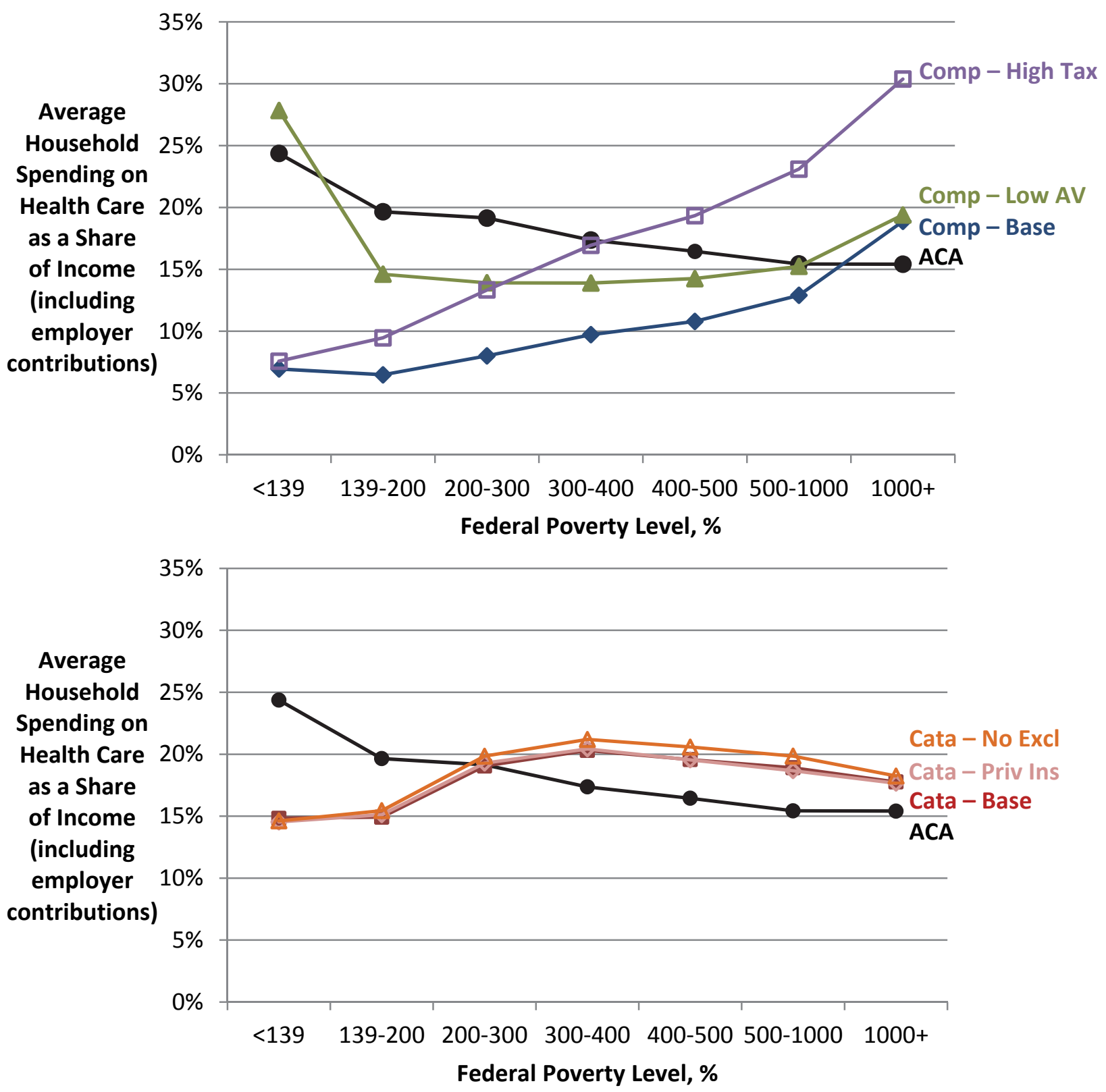

NOTES: In the numerator of spending as a share of income, household spending on health care includes premiums (paid by individuals and employers), out-of-pocket payments, federal income taxes devoted to health care programs, penalty payments (ACA), state income taxes devoted to Medicaid, Medicare payroll tax, single-payer taxes, and the value of the ESI tax exclusion. The income denominator includes household income plus employer premium contributions for health care benefits. I estimated the FPL to be $\$ 12,409$ for a single individual and $\$ 25,359$ for a family of four in 2017, based on the 2014 Department of Health and Human Services (HHS) poverty guidelines and inflated using the consumer price index estimated by the Congressional Budget Office (CBO).

2017. The low-AV comprehensive scenario resulted in a U-shaped trend with the lowest income households ( $<139 \%$ FPL) and the highest income households $(\geq 1000 \%$ FPL) paying $14 \%$ and 
$26 \%$, respectively, more than what they paid under the ACA, and the middle income households paying less on average. With tax levels adjusted to cover the $98 \% \mathrm{AV}$ plan in the high-tax comprehensive scenario, households $<300 \%$ FPL paid $31-70 \%$ of what they paid under the ACA, and households $\geq 300 \%$ FPL paid up to nearly twice as much. The catastrophic scenarios reduced household spending to as low as $60 \%$ of payments under the ACA or had little change in health payments for households $<300 \%$ FPL due to subsidies, while households $\geq 300 \%$ FPL paid 15 $29 \%$ more relative to the ACA.

In addition to changes in household spending on health care, workers in the model experienced a wage increase if their employer reduced spending on health benefits as part of their total compensation package (Table 3.4). I estimated total wages and salaries would increase by $\$ 187$ billion (average $\$ 1,420$ per worker) in the comprehensive scenarios and $\$ 454-613$ billion (average $\$ 3,460-4,680$ per worker) in the catastrophic scenarios due to the pass back of compensation, previously provided as health benefits, in the form of wages.

Table 3.4. Wage Pass Backs

\begin{tabular}{lrrrrr}
\hline & ACA & Comp & Cata-Base & Cata-Priv Ins & Cata-No Excl \\
\hline Total wages, billions & $\$ 8,503$ & $\$ 8,690$ & $\$ 9,116$ & $\$ 8,957$ & $\$ 8,987$ \\
Total wages relative to ACA, billions & - & $\$ 187$ & $\$ 613$ & $\$ 454$ & $\$ 484$ \\
Total wage increase per worker & - & $\$ 1,420$ & $\$ 4,680$ & $\$ 3,460$ & $\$ 3,690$ \\
\hline
\end{tabular}

Although the above household spending includes employer premium contributions, I also examined employer spending alone. Firms spent about the same or less on average than they did under the ACA (Appendix D). However, firms that did not offer insurance under the ACA would pay much more under comprehensive scenarios with mandatory payroll taxes. 


\section{Effects of Other Savings and Costs}

The categories of savings and costs that arose from the literature review were insurer administration, hospital administration, physician administration, other administration (e.g., nursing homes, home health agencies), drug prices, provider payment, start-up costs, and transition costs (e.g., training for displaced workers).

A single payer is hypothesized to reduce administrative costs through reduced overhead, billing, and claims processing. As governmental administrative costs are typically lower than private administrative costs of insurance, insurer overhead may decrease with reduced marketing activities and profits. ${ }^{13}$ Provider administration by hospitals, physicians, and other health facilities and agencies may decline due to reduced billing and insurance-related activities and staff time dedicated to filing claims.

In addition to administrative savings, savings from reduced drug and provider payments are hypothesized. A single payer may be able reduce drug prices through bulk purchasing and negotiations as a monopsonist; a drug formulary would likely need to be established. Although financing by a single payer does not directly affect provider payment, proposals often include payment reform and a single payer has more budgetary control. Global budgets and payment models, such as accountable care organizations and medical homes with capitation, may help reduce provider payment rates, but the extent to which they would be reduced is unclear. On the other hand, a single-payer system that absorbs Medicaid and has a uniform payment schedule may need to increase payment rates to Medicaid providers.

Implementation of a single-payer system would likely require some start-up and transition costs. Some proposals indicate that funds would be needed to buy out investor-owned health care

\footnotetext{
${ }^{13}$ However, managed care administration, utilization review, and prior authorizations may also be reduced and could have negative effects.
} 
facilities in order to convert facilities from for-profit to not-for-profit, while other proposals include the cost of training displaced workers from the private insurance industry in the initial transition to a single-payer system.

Ranges of estimates for each savings and cost category are shown in Table 3.5. Column A contains the status quo costs under the ACA, projected to 2017. Column B contains the estimated percentage change. Column $\mathrm{C}$ is the product of columns $\mathrm{A}$ and $\mathrm{B}$, and reflects the change in spending due to savings or costs. The base estimates are the mean in each range. ${ }^{14}$ The net effect of the base estimates was a $\$ 556$ billion reduction in spending (\$627 billion in savings and $\$ 71$ billion in costs). The most generous estimates resulted in a net savings of over $\$ 1.5$ trillion, while the most conservative estimates totaled to a net cost of $\$ 140$ billion.

The parameters from the literature were estimated based on comparisons with other countries, comparisons between U.S. programs, or assumptions without specific comparators. Most of the administrative savings estimates ( 26 of 35 ) were derived from comparisons with the Canadian health care system, while 6 of the estimates were based on within-U.S. comparisons, e.g., between private and public payers. Of the 35 administrative savings estimates, 27 were from four publications authored by researchers affiliated with the Physicians for a National Health Program (Grumbach et al., 1991; Woolhandler, Campbell and Himmelstein, 2003; Jiwani et al., 2014; Himmelstein et al., 2014). Four estimates of drug price reductions were based on crosscountry comparisons with the United Kingdom, Germany, France, Canada, and Denmark (Angrisano et al., 2007; Friedman, 2013; Baker, 2013), while four other estimates were based on within-U.S. comparisons between drug prices paid by the private sector, Medicare, Medicaid,

\footnotetext{
${ }^{14}$ If a single source produced multiple estimates by varying parameters, e.g., in a sensitivity analysis, an average value was used in the calculation of the mean across the different sources.
} 
Table 3.5. Ranges of Other Savings and Cost Estimates

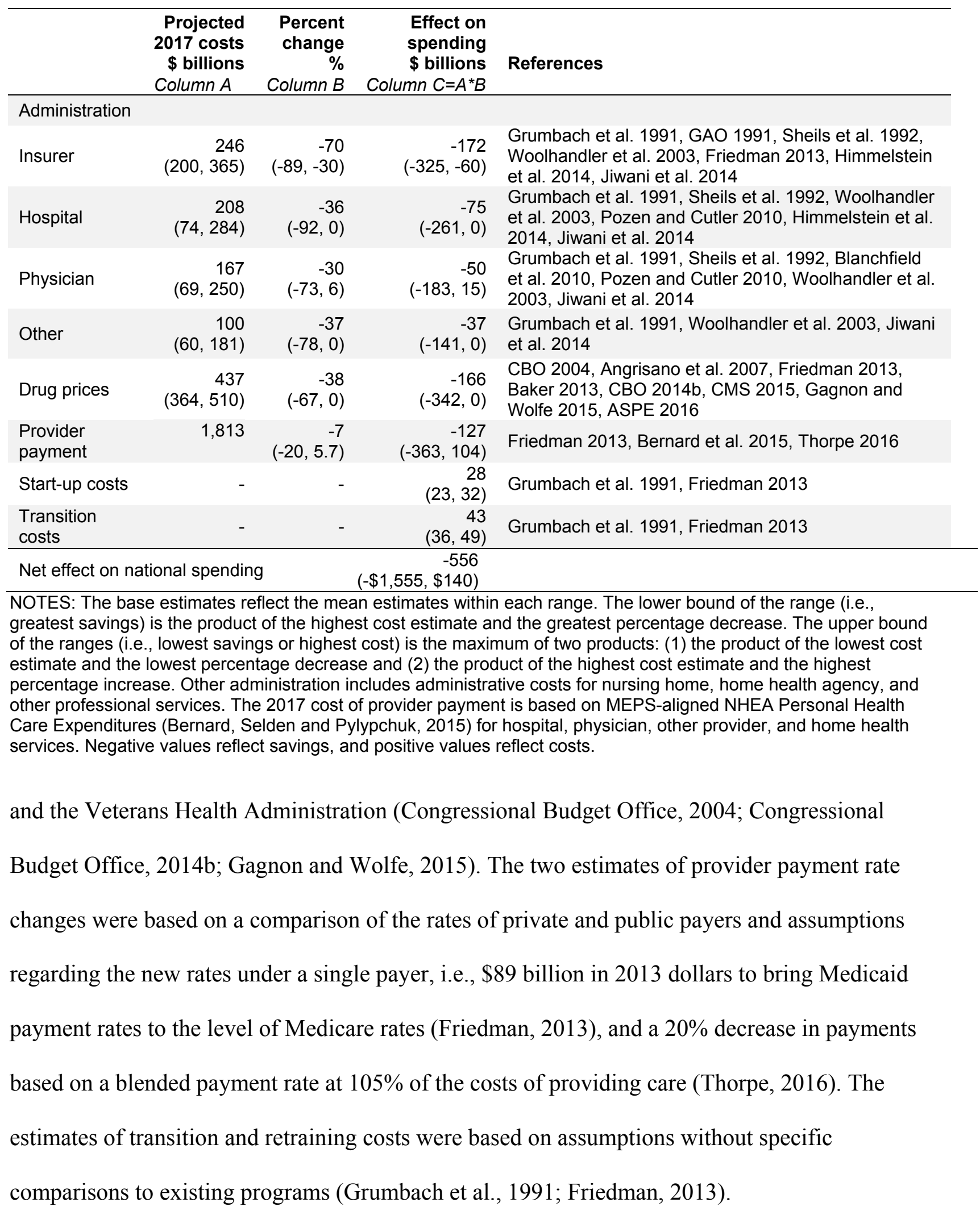


Table 3.6 shows the aggregate effects on national and federal health care spending before and after the savings and cost assumptions. For the base comprehensive scenario, federal spending was still higher than spending under the ACA after applying the mean estimates of other savings and costs; however, savings could be realized if more generous estimates of savings within the ranges were applied. An interactive cost tool that allows the savings and cost assumptions to be adjusted is described in Chapter 4. For the low-AV comprehensive scenario, the mean estimates of other savings and costs further increased the savings in national and federal spending; the generosity of this plan could be increased depending on the extent of the savings. Health care spending under the catastrophic scenarios was also further reduced by the mean estimates of other savings and costs.

Table 3.6. National and Federal Spending Before and After Savings and Cost Assumptions

\begin{tabular}{|c|c|c|c|c|}
\hline \multirow[t]{2}{*}{ Scenario } & \multicolumn{2}{|c|}{$\begin{array}{l}\text { National health care expenditures } \\
\text { relative to the ACA, } \$ \text { billions }\end{array}$} & \multicolumn{2}{|c|}{$\begin{array}{l}\text { Federal health care expenditures } \\
\text { relative to the ACA, } \$ \text { billions }\end{array}$} \\
\hline & $\begin{array}{l}\text { Before savings and } \\
\text { cost assumptions }\end{array}$ & $\begin{array}{l}\text { After savings and } \\
\text { cost assumptions }\end{array}$ & $\begin{array}{l}\text { Before savings and } \\
\text { cost assumptions }\end{array}$ & $\begin{array}{l}\text { After savings and } \\
\text { cost assumptions }\end{array}$ \\
\hline Comp-Base & 435 & $-121(-1,120,575)$ & 1,002 & $446(-553,1,142)$ \\
\hline Comp-Low AV & -179 & $-735(-1,734,-39)$ & 0 & $-556(-1,555, \quad 140)$ \\
\hline Comp-High Tax & 435 & $-121(-1,120,575)$ & 0 & $-556(-1,555,140)$ \\
\hline Cata-Base & -211 & $-767(-1,766,-71)$ & -40 & $-596(-1,595, \quad 100)$ \\
\hline Cata-Priv Ins & -109 & $-665(-1,664,31)$ & -23 & $-580(-1,579, \quad 117)$ \\
\hline Cata-No Excl & -107 & $-663(-1,662,33)$ & -29 & $-585(-1,584, \quad 111)$ \\
\hline
\end{tabular}

NOTE: Negative values reflect savings, and positive values reflect costs.

\section{Discussion}

Both the comprehensive and catastrophic single-payer systems insure more people than the ACA by providing universal coverage of citizens and legal residents. This study estimates that the comprehensive scenarios with generous benefits would be very expensive, while the catastrophic scenarios with income-dependent coverage would be cost-saving. 
While the financing in the single-payer scenarios were generally more progressive than the ACA, the comprehensive scenarios - depending on the plan and financing design - could increase payments for the lowest income individuals, as the comprehensive plan would replace Medicaid and all individuals would be subject to new taxes to finance the single-payer system. Particularly for some individuals below 139\% FPL who may have been eligible for Medicaid at virtually no cost, the burden of single-payer taxes or OOP payments with a moderate-AV plan could outweigh the benefits. In contrast, the catastrophic scenarios have progressive financing and progressive benefits: households below 300\% FPL have reduced or similar average payments relative to the ACA, as Medicaid program is retained, subsidies are provided to those below 300\% FPL, and coverage is income-dependent. However, health care spending would increase for households above 300\% FPL, which includes lower-middle and middle-income households.

The concepts of "comprehensive" and "catastrophic" coverage are not synonymous with more generous and less generous coverage. The comprehensive scenarios in this analysis are characterized by a uniform single-tiered plan - meaning that everyone covered by the plan gets the same benefits package. Although proposals for comprehensive coverage generally have high actuarial value, it is conceivable that a less generous single plan could be offered universally. The catastrophic scenarios have income-dependent coverage such that all covered individuals and families have plans that are unique to their income. For higher-income individuals, this translates to catastrophic coverage to cover large financial losses; a private insurance plan, if available, would be more likely to be their primary coverage rather than a wraparound plan. However, income-dependent coverage would be extremely generous for lower-income individuals, for which any medical expenses could result in catastrophic financial loss. 
The American Health Security Act is likely underfinanced with the proposed tax rates. According to economic theory and empirical evidence from the RAND Health Insurance Experiment, more generous insurance triggers moral hazard and increased utilization of health care services (Newhouse and The Insurance Experiment Group, 1993; Zweifel and Manning, 2000). The added costs of increased utilization and other implementation costs mean that more federal revenue would be needed, the deficit would grow, or additional savings would need to be squeezed out of the system. The upper range of the savings estimates outweighs the added cost of increased utilization with nearly free care for all; however, it is unknown whether the upper range of the savings estimates could be achieved. In order to fully finance universal coverage with the $98 \%$ AV scenario prior to other savings and costs, income and payroll tax rates needed to be raised by a combined $23.7 \%$ in this model.

The catastrophic scenario without private insurance options provided less generous coverage overall and was estimated to reduce health care spending even before factoring in potential administrative savings and reductions in drug and provider prices. A reduction of insurance benefits may have effects on health and wellbeing, although the RAND Health Insurance Experiment, which included a high-deductible catastrophic plan, generally did not find adverse effects on health due to cost sharing except for the sick poor (Newhouse and The Insurance Experiment Group, 1993). ${ }^{15}$ In order to achieve the Triple Aim (Berwick, Nolan and Whittington, 2008), any health care reform effort, including single-payer systems, would need to ensure that the quality of care is maintained or improved, which is no small task if the reform makes fundamental changes to financing, payment, and delivery mechanisms. However, the focus of this study was coverage and spending rather than the impact on quality of care and

\footnotetext{
${ }^{15}$ This should not be generalized to not having any health insurance; studies have shown adverse effects of uninsurance on health outcomes (Institute of Medicine, 2009).
} 
health outcomes. It is possible that there would be unintended consequences of incomedependent catastrophic coverage, particularly if the private market was prohibited from filling a demand for more comprehensive coverage.

In the catastrophic scenarios, the generosity of insurance coverage and the subsequent level of health care services depend on whether private insurance options were allowed alongside the catastrophic plan and the tax treatment of employer-sponsored insurance. When private insurance was available to complement the catastrophic coverage, more than $80 \%$ of the eligible population enrolled in private insurance, either through their employer or on the individual market. A limitation is that the elasticities of firm behavior with respect to tax price were estimated from small changes in tax price but were used to estimate the effect of eliminating the tax exclusion entirely. However, the resulting private insurance enrollment is consistent with the Medicare experience, in which $86 \%$ of Medicare beneficiaries have some type of supplemental coverage (Cubanski et al., 2015). In the catastrophic scenario allowing private insurance, ESI enrollment was five times greater than enrollment on the individual marketplace, as employees may prefer ESI due to the benefits of pooling with a healthy workforce, lower administrative costs due to firms' economies of scale, and ease of enrollment, in addition to the tax advantage of ESI. When the ESI tax exclusion is eliminated, ESI enrollment was lower as the tax treatment is less favorable, but ESI enrollment was still more than two times the enrollment on the individual marketplace.

A strength of the model presented here is that it builds upon existing evidence. Several models have been developed to explore the impact of health policies on insurance coverage and spending, including the RAND's COMPARE model (Cordova et al., 2013) and others (Buettgens, 2011; Congressional Budget Office, 2007; Foster, 2009; Gruber, 2011; Lewin 
Group, 2009). The COMPARE model uses evidence from the RAND Health Insurance

Experiment, and has been used to simulate the current status quo under the ACA (Ringel et al., 2010; Auerbach et al., 2011; Eibner and Saltzman, 2014). Findings from COMPARE have been widely consulted during the implementation of the ACA (Office of the Assistant Secretary for Planning and Evaluation, 2012; Finegold, 2014; Hellman et al., 2015).

The microsimulation uses person-level expenditures data that allow for an evaluation of distributional effects on household spending. However, the use of household survey data required adjustments to national benchmarks. Although the MEPS expenditures were adjusted using the Society of the Actuaries large claims data and aligned with NHEA Personal Health Care expenditures using established methods, there is a shortfall in expenditures due to differences in the data, such as long-term care expenditures being excluded. This is a known discrepancy of household survey data that are based on a different population and service types from the NHEA (Sing et al., 2006). Using the 2007 MEPS and NHEA data, Bernard et al. found a 17.6 percent discrepancy between MEPS and NHEA (Bernard et al., 2012). However, the exclusion of long-term care expenditures means that additional revenue sources not included in this analysis would be needed if the single-payer plan covered long-term services and supports.

Another limitation to the analysis of the comprehensive scenarios is that I only considered primary insurance coverage, i.e., spending was not attributed to secondary coverage although multiple coverage sources could occur. ${ }^{16}$ In the comprehensive scenarios, any secondary source of coverage would be supplementary or complementary to the single-payer plan and was not modeled. However, in reality, supplementary and complementary insurance would likely play an important role in a single-payer system, particularly if the benefits package was less than

\footnotetext{
${ }^{16}$ In the catastrophic scenarios, a second source of coverage in addition to the catastrophic single-payer plan was modeled because the attribution of primary coverage varied by household income, i.e., whether the catastrophic or private coverage would be one's primary source of coverage depended on income.
} 
adequate or if there were severe constraints on provider supply (White, 2009). With a high AV of $98 \%$, the adequacy of the benefits package would likely not be an issue; however, if the plan generosity was reduced, then individuals may seek complementary (or "gap") private coverage for benefits not covered by the single-payer plan. For example, Canadian health plans generally do not cover dental and prescription drugs, and many individuals enroll in private coverage for these benefits (White, 2009). Another example of "gap" coverage is Medicare supplemental plans in the U.S. In the case of supply constraints, individuals may seek supplementary (or "parallel") private coverage for improved access. For example, in some European countries, supplementary coverage may provide access to private providers, faster access, or increase choice of providers (Mossialos and Thomson, 2004). Supply constraints would likely be a larger issue in a single-payer system that aggressively reduced provider payment rates. The existence of a substantial market for parallel coverage could result in a multi-tiered system, which may threaten the single-payer system (e.g., less political support for single-payer taxes, fewer providers in the single-payer system) and create inequities in access (White, 2009).

Although there are many uncertain effects of a single payer, the best available evidence from the literature was used to estimate other savings and costs. However, there may be bias in the compiled literature if with studies showing large savings and costs were more likely to be published. To aid policymakers and interested parties in determining the appropriate levels for other savings and costs, I developed an interactive tool with guidance from the literature that allows the other savings and costs assumptions to be adjusted (see Chapter 4).

Simplistic percentage reductions in provider payment rates and drug prices that may be possible under a single payer were estimated based on parameters from the literature; however, there are other potential consequences not quantified here. Reduction in provider payment could 
constrain supply and result in wait lists (Hussey and Anderson, 2003; Emanuel, 2008), and could reduce innovation in the private insurance sector (Frakt, 2012). Reductions in drug prices may stifle pharmaceutical innovation (Calfee, 2001). A limitation of the simulation model is that the change in utilization of health care was assessed only from the demand side, meaning that only patient responses to cost sharing were considered. Any changes to the supply of health care services have not been considered in the present analysis. Provider responses to fundamental changes in payment arrangements, such as global budgets, accountable care organizations, patient-centered medical homes, and population-based payments, are influenced by different factors and are not well understood (Chen and Lakdawalla, 2016; Friedberg et al., 2015). Effects of provider responses are crucial to concerns about rationing of care and wait lists and should be explored in future research. ${ }^{17}$

\section{Summary}

This chapter describes estimates of health insurance coverage and spending due to changes in utilization, financing, administrative costs, provider and drug payments, and implementation costs in single-payer scenarios. Federal health care expenditures in the comprehensive scenarios that provide coverage to all legal residents and have little cost sharing were predicted to be higher than expenditures under the ACA. In contrast, I estimated that the catastrophic scenario would reduce overall expenditures even before factoring in other savings related to administration and price reductions. The body of evidence on other savings and costs associated with a single payer generated a wide range of estimates. In Chapter 4, I describe the development of a cost tool that incorporates the parameters relating to administrative costs, drug and provider prices, and implementation costs and allows the adjustment of the savings and cost assumptions.

\footnotetext{
${ }^{17}$ Research to better understand provider response to different payment arrangements would not be unique to singlepayer systems.
} 


\section{Cost tool}

This chapter describes the development of an interactive single-payer cost tool and the how to use the tool. The cost tool allows users to adjust the savings and cost assumptions that affect health care spending under single-payer scenarios. Rather than a single, static estimate of health care spending, users can view how spending changes given selected assumptions.

The purpose of the cost tool is to improve the transparency of the estimates by disaggregating the effects and allow users to view, in real time, the results of adjusting the assumptions underlying the effects. Manski (2013) has highlighted the importance of recognizing uncertainty in public policy analyses used to inform decision-making. This interactive tool is one step towards moving away from what Manski refers to as "incredible certitudes" and towards a more transparent portrayal of the assumptions underlying analyses based on partial or weak evidence.

\section{Tool Development}

The cost tool was created using the Shiny package, a web application framework for R. Shiny allows for "reactive" inputs and outputs in an interactive web application that responds to user inputs in real time.

The inputs to the tool are the simulation results on coverage and spending due to changes in utilization and financing, and the other savings and cost parameters relating to administration, drug and provider prices, and implementation, as described in Chapter 3. The simulation results include changes in patient utilization in response to cost sharing and changes in financing. The other savings and cost parameters consist of administrative costs incurred by insurers, hospitals, physicians, and other providers, drug prices, provider payment, start-up costs, and transition costs. 


\section{Cost Tool Instructions and Layout}

The top panel of the tool contains instructions for how to use the tool in four steps:

1. Select a scenario from the options below.

2. Set the plan and financing design parameters.

3. Click on the 'Savings \& Costs' tab and move the sliders to change the assumptions for each factor.

4. View the estimates in the 'National Spending', 'Federal Spending', 'Household Spending', and 'Coverage' tabs.

The tool consists of a split screen with three input tabs on the left ('Scenario,' 'Savings \& Costs,' and 'Sources') and four output tabs on the right ('National Spending,' 'Federal Spending,' 'Household Spending,' and 'Coverage').

\section{Scenario Tab}

In the 'Scenario' tab on the left-hand side, there are three panels (Figure 4.1). The first panel contains scenario selection with 'Comprehensive' and 'Catastrophic' options as radio buttons. A description of the comprehensive and catastrophic scenarios is given below the radio buttons.

The second panel allows users to set the plan parameters. If 'Comprehensive' is selected in the prior panel, then the plan parameter options are for the plan's actuarial value, ranging from $60 \%$ to $100 \%$. If 'Catastrophic' is selected, different plan parameters are shown. Two check box options are available: whether private insurance is allowed and whether the tax exclusion for employer-sponsored insurance is eliminated. Instead of actuarial value, the catastrophic plan is parameterized by an income-dependent deductible as a share of surplus income. The options for the share of surplus income are $5 \%, 10 \%$, and $20 \%$. With both scenario selections, an estimate for the resulting change in medical expenditures due to changes in utilization under the plan design is provided below the plan parameter settings; the estimate is updated whenever there is a change in the plan settings. 
The third panel allows users to set financing parameters. For 'Comprehensive,' there are parameters for income, payroll, and securities transaction taxes dedicated to the single-payer plan. The income tax options are a graduated income tax schedule based on the American

\section{Figure 4.1. Screenshot of the Scenario Tab}

\section{Scenario Savings \& Costs Sources}

\section{Select a scenario}

- Comprehensive

- Catastrophic

The comprehensive scenario provides all citizens and legal residents with uniform health insurance coverage. The plan and financing designs are based on two federal bills: the American Health Security Act (S. 1782, 113th Congress; H.R. 1200, 114th Congress) sponsored by Senator Bernie Sanders (DVT) and Representative Jim McDermott (D-WA), and the Expanded \& Improved Medicare For All Act (H.R. 676, 114th Congress) sponsored by Representative John Conyers (D-MI).

\section{Set plan parameters}

Actuarial value: The share of total average costs that a plan will cover. Higher actuarial value results in lower out-of-pocket payments and increased utilization of services.

$98 \%$

\section{Change in medical expenditures due to utilization: $+\$ 273 \mathrm{~B}$}

\section{Set financing parameters}

Income taxes: Dedicated income taxes for single-payer expenditures. The American Health Security Act proposes a graduated income tax from $2.2 \%$ to $5.2 \%$ plus $5.4 \%$ surcharge for high earners. The Medicare for All Act proposes an increase in personal income taxes for the top $5 \%$ of earners, and a modest tax on unearned income.

- Graduated income tax based on the American Health Security Act

Flat income tax

Payroll tax: Dedicated payroll tax on employers for single-payer expenditures. The American Health Security Act proposes a 6.7\% payroll tax rate on employers. The Medicare For All Act proposes a modest and progressive payroll tax; the tax rate is assumed to be the level set below for income $>=\$ 50,000$, and half the set rate for income $<\$ 50,000$, e.g., $3.35 \%$ for income $<\$ 50,000$ and $6.7 \%$ for income $>=\$ 50,000$.

\section{$6.7 \%$}


Health Security Act (S. 1782, 113th Congress) and a flat income tax. The flat income tax may be on the top 5\% of earners (as specified in the Expanded \& Improved Medicare For All Act [H.R. 676,114 th Congress]) or everyone who pays income taxes, and may be accompanied by an unearned income tax on investment income, property income, etc. Each tax has a drop-down menu from which a user can select the tax rate. For 'Catastrophic,' the per capita tax rate may be set. Based on the Health-Insurance Solution, the per capita tax rate would apply in full to individuals and households above $300 \%$ FPL, while those between 100-300\% FPL would receive subsidies on a linear scale and those below $100 \%$ FPL would not be taxed. In the current version of the tool, the options for the per capita tax rate are $\$ 1,675, \$ 2,000, \$ 3,350$, and $\$ 4,000$. A reset button that restores all parameters to the original settings is at the bottom of the page.

\section{Savings and Costs Tab}

The 'Savings \& Costs' tab consists of separate panels for each category of savings and cost. Within each panel, there is a slider and a drop-down menu that contains parameters from the literature as guidance (Figure 4.2). The user may either set the savings rate or cost using the slider or by selecting a value form the drop-down menu. If a value from the drop-down menu is selected, a brief description of the value from the literature is provided. The drop-down menu also contains a 'default' value that is the mean value across the estimates from the literature. For each savings rate, there is also a check-box option to change the status quo cost. Similarly, each status quo cost has a slider and drop-down menu with estimates from the literature. The savings rates are multiplied by the status quo costs to estimate the savings reduction. There are blank input boxes for other savings and other costs if the user chooses to input other categories of savings and costs that are not listed. 
The savings and costs are assumed to reduce federal expenditures for the single-payer plan.

The 'Sources' tab contains the references for the savings and cost parameters.

Figure 4.2. Screenshot of Sample Panels in the Savings \& Costs Tab

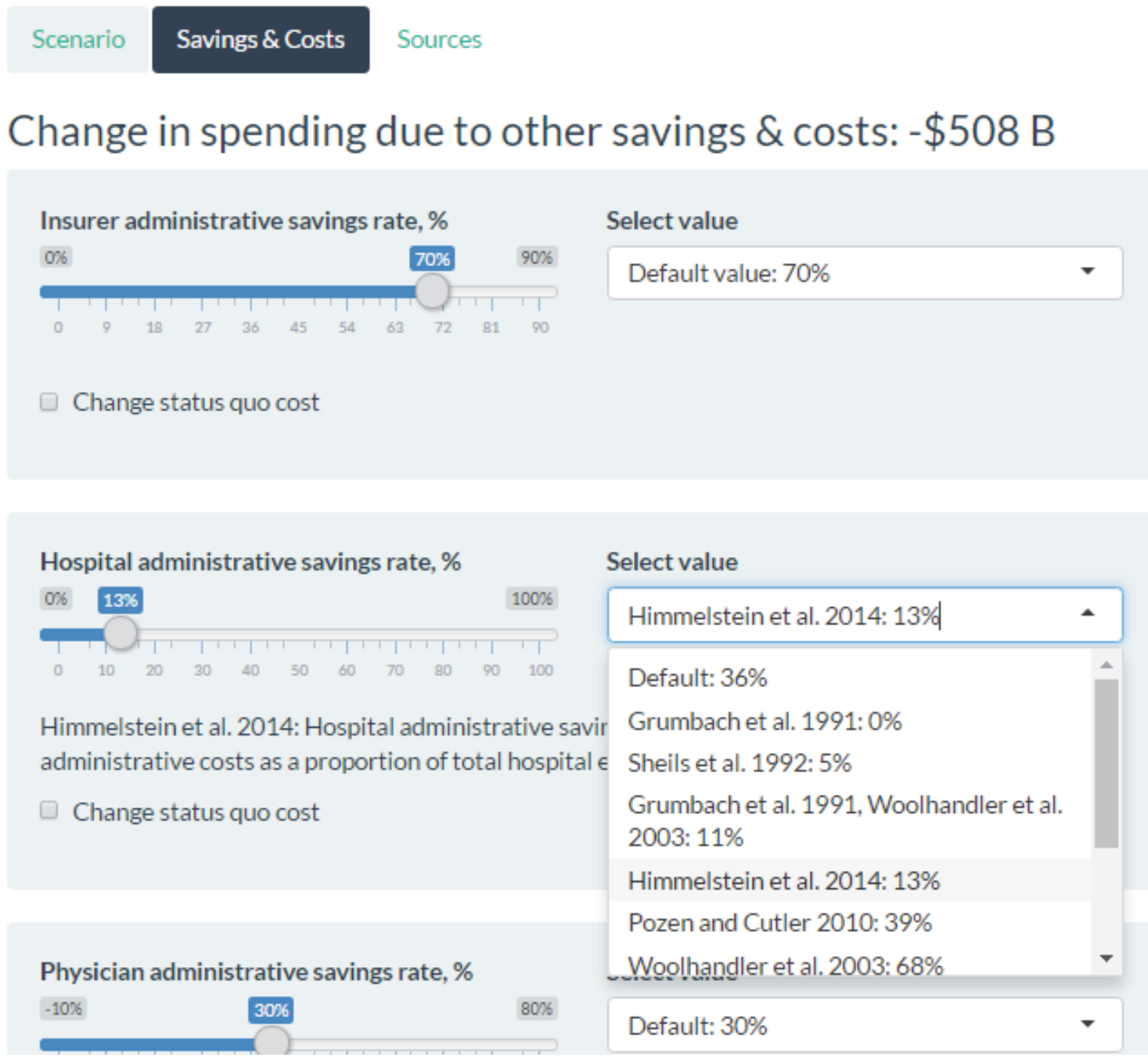

\section{Output Tabs}

The output tabs on the right-hand side contain estimates of national health care spending, the fiscal impact on federal health care spending, the distribution of average household spending on health care by income group, and health insurance coverage relative to the ACA in 2017 . The output tabs automatically update with changes to the input tabs. 
The output figures and tables are similar to those shown in Chapter 3. The national spending figure is a bar graph of the MEPS-aligned NHEA Personal Health Care expenditures plus administrative costs (Figure 4.3). Federal spending on health care is further broken down into sources of spending and revenue (Figure 4.4). Average household spending on health care as a share of total income (household income plus employer premium contributions for health care benefits) is shown as a line graph over federal poverty level categories (Figure 4.5). Primary health insurance coverage is shown as a proportion of the population in the U.S. (Figure 4.6).

Figure 4.3. Screenshot of the National Spending Tab

\section{National Spending Federal Spending Household Spending Coverage}

\section{Change in national health care spending: $-\$ 121 \mathrm{~B}$}

\section{Personal health care and administrative spending*}

Billions of dollars, 2017

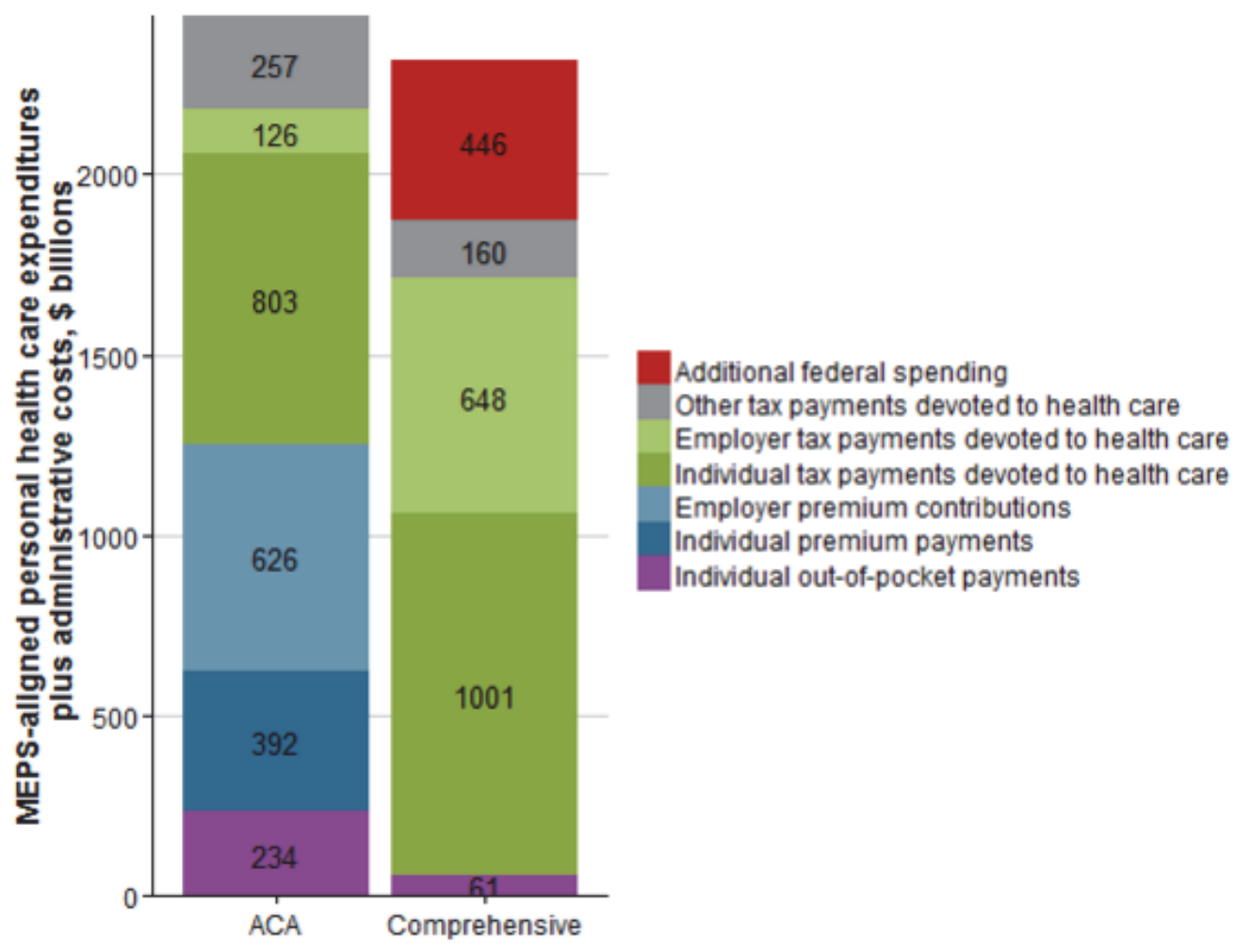


Figure 4.4. Screenshot of the Federal Spending Tab

Change in federal health care spending: $+\$ 445 \mathrm{~B}$

Direct spending and revenue by the federal government

Billions of dollars, 2017

ACA Comprehensive

HEALTH CARE EXPENDITURES

Medicare

Medicaid

Military

Exchange subsidies

Single payer

Uninsured

Government administration

SINGLE-PAYER COSTS

Start-up costs

Transition costs

Other costs

TOTAL OUTLAYS

REVENUE

Income tax devoted to health care

Medicare payroll tax

Penalty payments

Single-payer taxes

Drug prices

Payment rate adjustment

Other savings

TOTAL REVENUE AND SAVINGS

NET FEDERAL SPENDING RELATIVE TO ACA 
Figure 4.5. Screenshot of the Household Spending Tab

\section{National Spending Federal Spending Household Spending Coverage}

Payments for health care by household income

Average share of income spent on health care (\%), 2017

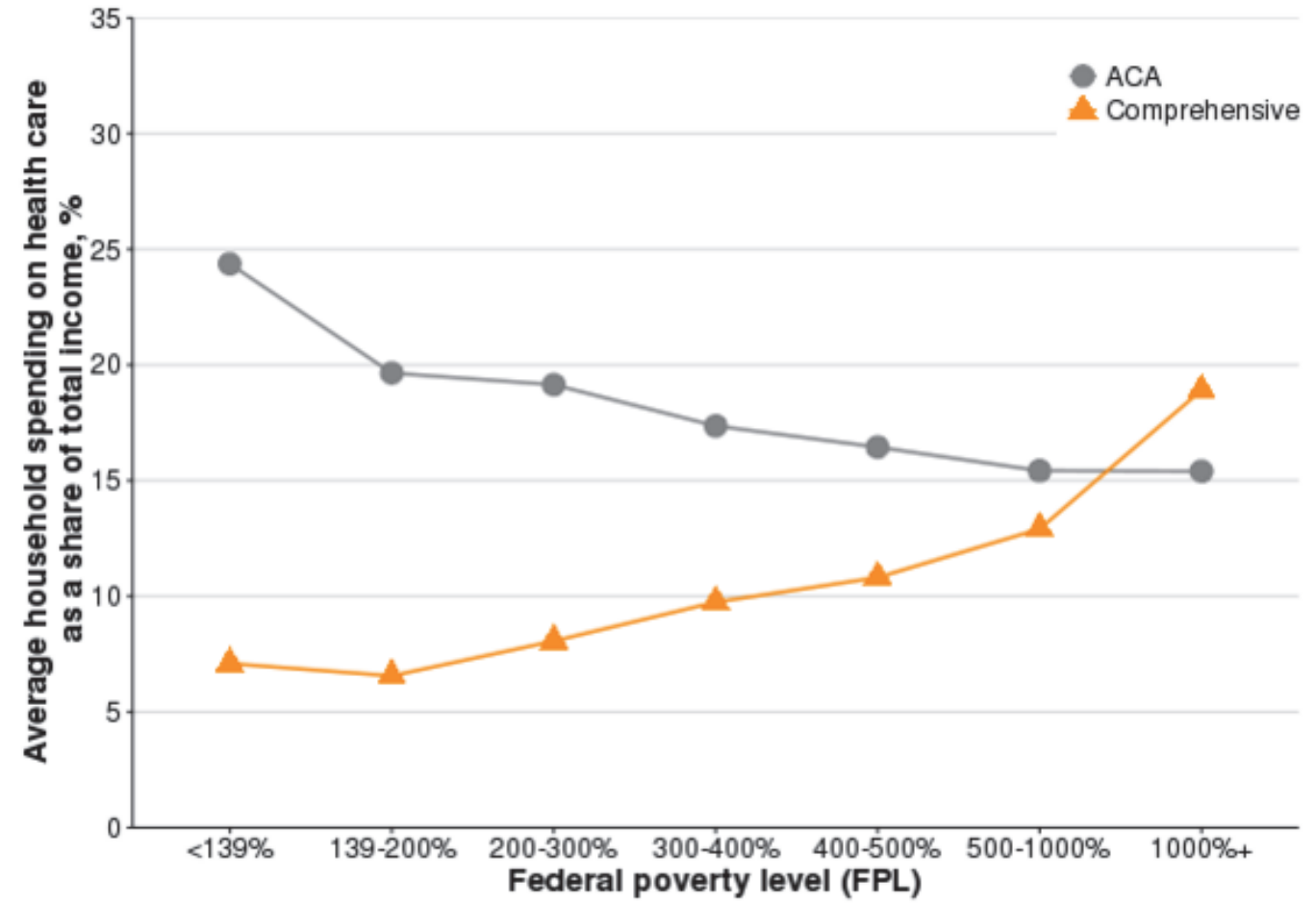

Total income includes household income plus employer premium contributions for health care benefits.

Figure 4.6. Screenshot of the Coverage Tab

\section{National Spending Federal Spending Household Spending Coverage}

\section{Health insurance coverage sources}

Share of population (\%) by primary health insurance, 2017

\begin{tabular}{|l|r|r|}
\hline & ACA & Comprehensive \\
\hline ESI & 48 & 0 \\
\hline Nongroup/Exchange & 8 & 0 \\
\hline Medicaid & 18 & 0 \\
\hline Medicare & 16 & 0 \\
\hline Military & 1 & 0 \\
\hline Single payer & 0 & 96 \\
\hline Uninsured & 9 & 4 \\
\hline
\end{tabular}




\section{Discussion}

For the effects with little existing evidence, an interactive cost tool with explicit ranges of possible savings and costs associated with single-payer systems was developed to aid interested parties in exploring the effects on spending.

The cost tool makes the assumptions about savings and costs associated with single-payer systems more transparent. Prior studies have produced a wide range of estimates of the effects of a single-payer system (General Accounting Office, 1991; Hsiao, Kappel and Gruber, 2011; Sheils, Young and Rubin, 1992; McDonough, 2015; London et al., 2013; Friedman, 2013; State of Vermont Agency of Administration, 2014; Thorpe, 2016; Committee for a Responsible Federal Budget, 2016; Holahan et al., 2016). Underlying these estimates are differences in methodology and assumptions (Sheils, Young and Rubin, 1992; McDonough, 2015). Laying out the categories of hypothesized savings and costs associated with a single payer and allowing real time visualization of how these savings and costs relate to health care spending increases transparency. The tool may be useful to interested parties as an aid to discuss the effects of a single-payer system, and could aid in the process of finding agreement in some assumptions and recognizing factors that are uncertain. Identifying agreed upon effects and uncertainties is a starting point to discussions of the merits and detriments of single-payer systems and how an optimal single-payer plan, if any, could be designed for the U.S. context. ${ }^{18}$

A key limitation of the cost tool is that many complex effects are greatly simplified in the tool. Each of the other savings and cost categories can be adjusted as a percentage reduction. In particular, provider payments, in reality, could be designed in numerous different ways and could

\footnotetext{
${ }^{18}$ Within the U.S. context, any potential single-payer system would be complicated further by implementation challenges in the transition from multiple systems.
} 
involve changes in provider behavior, supply, access, and utilization. However, supply-side effects of changing payment policies are not yet included in the cost tool.

There is a trade-off between allowing users the freedom to adjust each savings and cost, and restricting each savings and cost to adhere to a set of beliefs. For this first iteration of the tool, I favored the former approach, largely because there isn't consensus on many of these savings and costs. Further iterations of the tool could provide more guidance for users to consider more nuances about the choices they make for each savings and cost. For example, considerations for administrative costs may be different whether the comprehensive or catastrophic scenario is selected, or whether a private entity would be contracted by the government for some administrative tasks. In addition, administrative activities embody a variety of different tasks, of which some users may believe are useful (e.g., utilization review to reduce unnecessary medical services) or wasteful (e.g., utilization review that is an additional step to getting necessary medical services; marketing activities).

Although many effects of a single-payer system are uncertain, the best available evidence from the literature was used to provide guidance for setting the savings and cost assumptions in the cost tool. An interactive web application has an advantage of being easily adaptable and updated when new evidence becomes available. 


\section{Conclusion}

The policy debate on health care reform includes both major policy changes and marginal changes to the existing health care system. The aim of this dissertation was to examine one set of major policy changes that have been proposed: single-payer health care. I examined the evidence and variation in single-payer alternatives that would replace the current system and eliminate private insurance as a primary source of insurance coverage. With any major policy change, there is substantial uncertainty in the projected impact. I attempted to reduce the uncertainties around the estimated effects of a single-payer system on health care spending by disaggregating the effects by the strength of evidence. To promote transparency and to further a more nuanced policy debate, I acknowledged areas in which uncertainties remain.

I conducted a literature review on definitions of single-payer systems and health care reform proposals involving a single payer in the U.S. at the national and state levels. In political discourse, single-payer systems are frequently treated as homogeneous. Yet numerous attributes are variable and some are associated with a single-payer system but not necessarily characteristic of all systems that may be labeled as single-payer. I observed substantial variation in what single-payer means and how it has been proposed to be put into practice. I found Tuohy's (2009) characterization of a single-payer system within a broader, hybrid system to be useful for the U.S. context. This perspective considers a single-payer system as a government plan that does not compete with other insurers and may be restricted in scope by the population, services, and jurisdiction. This characterization is inclusive of variations of single-payer systems that are relevant for the U.S., such as state-based systems and systems providing catastrophic coverage, while providing some structure for how to characterize a system. While strict definitions of a 
single-payer system are primarily focused on financing, most proposals contain a heterogeneous set of provisions and operationalize the shift to a single-payer system as a wide-ranging reform effort that includes changes across health care system functions of financing, payment, and delivery.

Based on the review of recent proposals, there are numerous variations that are possible across single-payer systems. I modeled two extremes in terms of plan design in order to illustrate the potential effects on spending. The two sets of national scenarios are based on existing proposals: the American Health Security Act and the Health-Insurance Solution. The first set of scenarios has comprehensive coverage with little cost sharing, i.e., a nearly free care-for-all plan. The second set of scenarios has income-dependent coverage intended to protect beneficiaries from catastrophic financial losses. These two extremes in plan types were selected in order to highlight a range of possibilities within the design of a single-payer system. Other key characteristics of a single-payer system were constant across these illustrative scenarios: both are national single-payer scenarios that provide coverage for all citizens and legal residents and are tax-financed. I showed examples of how both sets of scenarios can be adjusted to alter overall spending and the distribution of spending. For the comprehensive coverage, I modeled alternative scenarios with variations in the plan generosity and tax levels. For the catastrophic plan, I modeled alternative scenarios allowing supplemental private insurance options and eliminating the tax exclusion of employer-sponsored insurance.

In addition to the lack of consensus on what single-payer means, there is substantial variation in the estimated effects of single-payer systems on health care spending. The wide range of estimated effects may be partially due to differences in the modeled scenarios and methodologies. However, a commonality in the analyses is many assumptions had to be made in 
order to estimate the effects of major changes that have not been previously observed in the U.S. context. The assumptions are often rooted in a relatively weak evidence base.

In order to contribute to the existing body of analyses, I disaggregated the effects of singlepayer systems and acknowledged the strength of evidence. I used an established model, RAND's COMPARE model, to estimate changes in utilization of health services in response to changes in coverage and cost sharing. COMPARE is a microsimulation model that has been used to assess the impact of the ACA, and makes use of the demand curve from the RAND Health Insurance Experiment. With some customization and modifications for the single-payer cases, I used COMPARE and tax parameters to estimate insurance coverage, national health care spending, federal health care spending, and the equity of household spending on health care by income due to changes in utilization and financing. In order to estimate the effects of other savings and costs associated with a single payer, including administrative efficiencies, increased purchasing power and budgetary control, and implementation costs, I relied on parameters from the literature, which are typically based on cross-country comparisons, comparisons between U.S. programs, and assumptions. Rather than producing a static set of estimates based on a relatively weak evidence base, I developed a web-based cost tool that allows for adjustments of the savings and costs assumptions that affect the final estimates in real time.

I estimated that increased utilization from insuring more people and providing generous coverage in the base comprehensive scenario would increase national health care spending by $\$ 435$ billion and federal spending by $\$ 1$ trillion relative to the ACA, prior to other savings and costs related to administration, price changes, and implementation. Although federal spending would increase considerably (unless other savings are enormous), premiums for private insurance coverage totaling $\$ 918$ billion would be replaced by the increased funds flowing 
through the federal government. The additional federal spending could be addressed by reducing the generosity of the plan or by increasing taxes.

The effect of utilization changes in the base catastrophic scenario would reduce national health care spending by $\$ 211$ billion and federal spending by $\$ 40$ billion relative to the ACA, prior to other savings and costs. Allowing supplemental private insurance options alongside the catastrophic plan would reduce the national savings by nearly half, with over $80 \%$ of eligible beneficiaries estimated to enroll in private insurance. Average household spending on health care as a share of total income was progressive by income in the catastrophic scenarios, with households with income below three times the federal poverty level paying less and households above that threshold paying more than they did under the ACA.

For the effects of other savings and costs such as administrative costs, drug and provider prices, and implementation costs associated with a single payer, I summarized the available evidence from the literature. The net effect of the other savings and costs ranged from over $\$ 1.5$ trillion in savings to $\$ 140$ billion in costs, with a mean estimate of $\$ 556$ billion in savings. If this mean estimate was applied to the comprehensive scenario, national health care expenditures would be reduced by $\$ 121$ billion; however, federal expenditures would still be $\$ 446$ billion higher relative to the ACA. There would be cost savings to the federal government only if the upper range of the savings assumptions was applied. In order to highlight the effects of different assumptions, the interactive cost tool can be used to adjust the savings and costs assumptions and to view the resulting effects on spending in real time. The cost tool contains categories of the different savings and costs and is accompanied by parameters from the literature to help guide the decision for each assumed savings and cost. The interactive cost tool is meant to promote 
transparency in how the different savings and cost parameters affect spending, and may be adapted when new evidence emerges.

Both the comprehensive and catastrophic single-payer scenarios would increase insurance coverage relative to the ACA by covering all citizens and legal residents. Although varying types and levels of health insurance have minimal effects on health status (Newhouse and The Insurance Experiment Group, 1993), being uninsured has been shown to have adverse effects on health (Institute of Medicine, 2004; Institute of Medicine, 2009). In contrast to the ACA, which preserves much of the fragmentation of the U.S. health care system and has gaps in coverage in part due to states not expanding Medicaid, both sets of single-payer scenarios could be a more direct way to achieve universal coverage. In addition, the single-payer alternatives could be designed to improve vertical equity with average household spending on health care being more progressive by income.

In the comprehensive scenarios, the expected increase in utilization and spending outweigh the estimated savings to the federal government unless extreme assumptions are made. Policymakers who want to provide generous, nearly free care for all should ensure adequate financing is available to fund the program. Although catastrophic, income-dependent coverage may not traditionally be discussed in the context of single-payer systems, a catastrophic singlepayer system financed through taxes may be a viable alternative that policymakers should consider. Relative to the ACA, the catastrophic scenarios increased insurance coverage without increasing overall health care spending. Additional research would be needed to assess whether any improvements in health are worth the additional cost of comprehensive coverage, and conversely, whether the savings with catastrophic coverage are worth possible adverse effects on health, if any. 
This dissertation does not address quality and value of care; rather, it is focused on coverage and spending. I also focused on utilization more than the other effects because strong evidence on how cost sharing affects utilization is available. The changes in utilization are estimated using the demand curve from the RAND Health Insurance Experiment. Although evidence from the RAND Health Insurance Experiment is still considered the gold standard for predicting the use of health care services in response to cost sharing, a limitation is that the evidence is several decades old. Another limitation is that I greatly oversimplified many complex effects in the cost tool. For example, the price reductions for drugs and provider payments may be adjusted on a simple percentage basis; however, aggressive price reductions may have complex consequences on medical innovation and provider supply, which can affect patient access, quality of care, and health. This work includes medical expenditures, but does not include long-term care expenditures. If coverage of long-term care was included in a single-payer payer plan, the projected expenditures would be greater than those estimated in this work. I also did not account for any potential changes in medical technology or how health care is delivered; this dissertation provides estimates in illustrative scenarios of what coverage and spending might look like under national single-payer alternatives in the near future.

Single-payer systems are often portrayed in extremes, as a silver bullet to universal health care access and to curb spending or as a socialist plot to control spending by rationing health care. Indeed, Stone (2009) argues that the term is more of a political metaphor than an actual descriptor of a health care system. As with most systems, the reality of a single payer is necessarily more complicated than simple metaphors with clear or automatic benefits or consequences; rather, a single-payer system would consist of a multitude of design and 
implementation decisions that would shape the effects on insurance coverage and spending, as well as access, quality, and health outcomes.

A goal for this dissertation was to make the estimation as transparent as possible for policymakers and decision-makers who may consider a major change in the U.S. health care system that moves away from private insurance as the primary source of coverage. Policymakers considering any type of single-payer system should recognize the uncertainties in the estimated effects and that the effects may be sensitive to details in how the single-payer system is designed. The estimates summarized in this work and the cost tool may aid policymakers in distinguishing the different effects that may be possible with single-payer system. I hope recognition of the variation in single-payer systems and the disaggregation of the effects of a single-payer system on spending can help facilitate a more nuanced policy discussion on future health care reform efforts. 


\section{Appendix A: Proposal Provisions for Access, Quality, and Cost Reduction}

\section{Table A.1. Measures to Improve Access, Quality, and Cost Reduction}

\begin{tabular}{|c|c|c|c|}
\hline Proposal/Bill & Access & Quality & Cost \\
\hline \multirow{4}{*}{$\begin{array}{l}\text { Proposal of the } \\
\text { Physicians' } \\
\text { Working Group } \\
\text { for Single-Payer } \\
\text { National Health } \\
\text { Insurance } \\
(2003)\end{array}$} & $\begin{array}{l}\text { Coverage of all Americans for a } \\
\text { comprehensive benefit package }\end{array}$ & \multirow[t]{3}{*}{$\begin{array}{l}\text { Exclusion of unnecessary or ineffective } \\
\text { services from benefit package }\end{array}$} & $\begin{array}{l}\text { Total expenditures set at an approximate } \\
\text { proportion of GDP in the prior year }\end{array}$ \\
\hline & \multirow[t]{2}{*}{$\begin{array}{l}\text { No copayments and deductibles for } \\
\text { covered benefits }\end{array}$} & & $\begin{array}{l}\text { Global budgets for operating expenses of } \\
\text { hospitals, long-term care facilities, and home } \\
\text { care agencies; capital spending allocation } \\
\text { determined by regional health planning boards }\end{array}$ \\
\hline & & & $\begin{array}{l}\text { Three provider payment options: (1) fee-for- } \\
\text { service from one fee schedule negotiated by } \\
\text { the national program and provider } \\
\text { representatives, (2) salaries in institutions with } \\
\text { global budgets, and (3) salaries in capitated } \\
\text { group practices and non-profit HMOs }\end{array}$ \\
\hline & & Establishment of a national formulary for presc & tion drugs and medical supplies \\
\hline \multirow[t]{4}{*}{$\begin{array}{l}\text { Health- } \\
\text { Insurance } \\
\text { Solution (2012) }\end{array}$} & \multirow{3}{*}{$\begin{array}{l}\text { Coverage of all legal residents for } \\
\text { catastrophic costs } \\
\text { Subsidized premiums for individuals with } \\
\text { income }<300 \% \text { FPL }\end{array}$} & $\mathrm{n} / \mathrm{a}$ & \multirow{2}{*}{$\begin{array}{l}\text { Elimination of federal tax subsidies for } \\
\text { employer contributions to employee health } \\
\text { insurance }\end{array}$} \\
\hline & & & \\
\hline & & \multicolumn{2}{|c|}{$\begin{array}{l}\text { Establishment of an online database with pricing and quality ratings of providers, goods, } \\
\text { services }\end{array}$} \\
\hline & \multicolumn{3}{|c|}{$\begin{array}{l}\text { Could have exceptions of no deductibles for high-value preventive care and treatment, and lower deductibles for people with chronic conditions } \\
\text { leading to high health care expenses }\end{array}$} \\
\hline \multirow{3}{*}{$\begin{array}{l}\text { Expanded \& } \\
\text { Improved } \\
\text { Medicare For All } \\
\text { Act (HR 676, } \\
\text { 113th } \\
\text { Congress) }\end{array}$} & $\begin{array}{l}\text { Coverage of all residents for a } \\
\text { comprehensive benefit package } \\
\text { No cost sharina for covered benefits }\end{array}$ & $\begin{array}{l}\text { Provider facilities must meet state quality and } \\
\text { licensing guidelines }\end{array}$ & $\begin{array}{l}\text { Budgets for operation (including provider } \\
\text { payments), capital expenditures, health } \\
\text { professional education }\end{array}$ \\
\hline & $\begin{array}{l}\text { Substitutive private insurance prohibited, } \\
\text { complementary insurance not restricted }\end{array}$ & \multicolumn{2}{|c|}{ Establishment of a standardized, confidential electronic patient record system } \\
\hline & ment of a National Board of & S, & pr \\
\hline
\end{tabular}




\begin{tabular}{|c|c|c|c|}
\hline Proposal/Bill & Access & Quality & Cost \\
\hline \multirow{8}{*}{$\begin{array}{l}\text { American } \\
\text { Health Security } \\
\text { Act (S 1782, } \\
\text { 113th Congress } \\
\text { / HR 1200, } \\
\text { 114th } \\
\text { Congress) }\end{array}$} & \multirow{6}{*}{$\begin{array}{l}\text { Coverage of all residents for a } \\
\text { comprehensive benefit package } \\
\text { Establishment of an enrollment system, } \\
\text { with enrollment available at employers, } \\
\text { Social Security offices, social services sites, } \\
\text { providers, community health centers, post } \\
\text { offices, schools }\end{array}$} & \multirow{5}{*}{$\begin{array}{l}\text { Establishment of the American Health Security } \\
\text { Quality Council to oversee practice guidelines, } \\
\text { standards of quality, performance measures } \\
\text { Establishment of the Center for American } \\
\text { Health Security Innovation to investigate new } \\
\text { models of care }\end{array}$} & \multirow{7}{*}{$\begin{array}{l}\text { Global budget caps on total health care } \\
\text { expenditures and subcomponents (quality } \\
\text { assessment, health professional education, } \\
\text { administrative costs, operating and other } \\
\text { costs) } \\
\text { Administrative expenditures not to exceed 3\% } \\
\text { of total expenditures }\end{array}$} \\
\hline & & & \\
\hline & & & \\
\hline & & & \\
\hline & & & \\
\hline & & \multirow{2}{*}{$\begin{array}{l}\text { State programs to conduct quality review of } \\
\text { services }\end{array}$} & \\
\hline & No copayments for covered benefits & & \\
\hline & $\begin{array}{l}\text { Continuous coverage of benefits for } \\
\text { individuals when establishing residence in a } \\
\text { different state }\end{array}$ & \multicolumn{2}{|c|}{ Establishment of a health security "smart" card for identification and claims processing } \\
\hline \multirow{6}{*}{$\begin{array}{l}\text { National Health } \\
\text { Insurance Act } \\
\text { (HR 15, 111th } \\
\text { Congress) }\end{array}$} & $\begin{array}{l}\text { Coverage of individuals meeting income } \\
\text { thresholds for a comprehensive benefit } \\
\text { package }\end{array}$ & $\begin{array}{l}\text { Provider payments to be adequate to } \\
\text { incentivize providers to advance careers and } \\
\text { provide high quality services }\end{array}$ & $\begin{array}{l}\text { Annual budget for overall expenditures and } \\
\text { each type of medical service }\end{array}$ \\
\hline & Patient choice of any general practitioner; & \multirow{5}{*}{$\begin{array}{l}\text { The board to study and recommend needed } \\
\text { benefits }\end{array}$} & $\begin{array}{l}\text { Administrative expenditures not to exceed } 5 \% \\
\text { of total expenditures }\end{array}$ \\
\hline & $\begin{array}{l}\text { need specialty referral unless waived by the } \\
\text { board }\end{array}$ & & \multirow{2}{*}{$\begin{array}{l}\text { If funds, facilities, or personnel are inadequate, } \\
\text { the board may limit benefits for a period of } \\
\text { time }\end{array}$} \\
\hline & Cost sharing allowed for improved services & & \\
\hline & & & \multirow{2}{*}{$\begin{array}{l}\text { DHHS to conduct study of cost control } \\
\text { methods }\end{array}$} \\
\hline & $\begin{array}{l}\text { Surveys of resources and needs in each } \\
\text { state }\end{array}$ & & \\
\hline
\end{tabular}




\begin{tabular}{|c|c|c|c|}
\hline Proposal/Bill & Access & Quality & Cost \\
\hline \multirow{8}{*}{$\begin{array}{l}\text { An act to } \\
\text { establish a } \\
\text { single-payor } \\
\text { health care } \\
\text { system to be } \\
\text { effective in } 2017 \\
\text { (Maine, HP 962, } \\
\text { 2013) }\end{array}$} & $\begin{array}{l}\text { Coverage of all Maine residents for a } \\
\text { comprehensive benefit package }\end{array}$ & \multirow{8}{*}{$\begin{array}{l}\text { The quality assurance program, to evaluate } \\
\text { provider performance, provide standards of } \\
\text { care, and resolve complaints on quality of } \\
\text { care, utilization, and rates } \\
\text { Establishment of incentives to providers to } \\
\text { maintain quality of care }\end{array}$} & \multirow{8}{*}{$\begin{array}{l}\text { An act to establish a single-payor health care } \\
\text { system to be effective in } 2017 \text { (Maine, HP 962, } \\
\text { 2013) }\end{array}$} \\
\hline & $\begin{array}{l}\text { Inclusion of long-term care benefits to be } \\
\text { studies by the Maine Health Care Agency }\end{array}$ & & \\
\hline & $\begin{array}{l}\text { Individuals must apply for a plan card and } \\
\text { pay premiums to be eligible for the plan }\end{array}$ & & \\
\hline & $\begin{array}{l}\text { Patient choice of participating providers and } \\
\text { facilities }\end{array}$ & & \\
\hline & $\begin{array}{l}\text { Cost sharing may be used to encourage the } \\
\text { use of appropriate and cost effective } \\
\text { services }\end{array}$ & & \\
\hline & $\begin{array}{l}\text { Coverage of out-of-state health care if } \\
\text { beneficiary is out of the state for reasons } \\
\text { other than health care; payments at } \\
\text { comparable rates }\end{array}$ & & \\
\hline & $\begin{array}{l}\text { Substitutive insurance prohibited; } \\
\text { complementary insurance allowed }\end{array}$ & & \\
\hline & $\begin{array}{l}\text { Establishment of programs for underserved } \\
\text { low-income and rural areas }\end{array}$ & & \\
\hline \multirow{5}{*}{$\begin{array}{l}\text { An act relating } \\
\text { to a universal } \\
\text { and unified } \\
\text { health system } \\
\text { (Vermont, H } \\
202,2011)\end{array}$} & $\begin{array}{l}\text { Coverage of all Vermont residents for a } \\
\text { comprehensive benefit package }\end{array}$ & \multirow{4}{*}{$\begin{array}{l}\text { GMCB to ensure provider reimbursement } \\
\text { levels such that high-quality health } \\
\text { professionals can be recruited and retained in } \\
\text { Vermont }\end{array}$} & GMC budget to be determined annually \\
\hline & $\begin{array}{l}\text { Inclusion of dental, vision, hearing, and } \\
\text { long-term care benefits to be determined by } \\
\text { the Green Mountain Care Board (GMCB) }\end{array}$ & & $\begin{array}{l}\text { Cost containment strategies to be determined } \\
\text { by GMCB, e.g., provider cost containment } \\
\text { targets, global payments, bundled payments, } \\
\text { global budgets, risk-adjusted capitated }\end{array}$ \\
\hline & Cost sharing to be determined by GMCB & & payments, or other provider arrangements \\
\hline & \multirow{2}{*}{$\begin{array}{l}\text { No restrictions on private insurance yet; the } \\
\text { secretary of administration to determine } \\
\text { whether to allow private insurance after } \\
\text { GMC is implemented }\end{array}$} & & $\begin{array}{l}\text { Payment reform pilots to be developed by the } \\
\text { department of Vermont health access }\end{array}$ \\
\hline & & \multicolumn{2}{|c|}{$\begin{array}{l}\text { Department of Vermont Health Access to provide recommendations for a single prescription } \\
\text { drug formulary }\end{array}$} \\
\hline
\end{tabular}




\begin{tabular}{|c|c|c|c|}
\hline Proposal/Bill & Access & Quality & Cost \\
\hline \multirow{10}{*}{$\begin{array}{l}\text { An act } \\
\text { establishing } \\
\text { Medicare for all } \\
\text { in } \\
\text { Massachusetts } \\
\text { (Massachusetts, } \\
\text { S 515, 2013) }\end{array}$} & \multicolumn{2}{|c|}{ Regional division and offices to do outreach locally and respond to patient feedback } & Global budget \\
\hline & $\begin{array}{l}\text { Coverage of all Massachusetts residents for } \\
\text { a comprehensive benefit package }\end{array}$ & \multirow{2}{*}{$\begin{array}{l}\text { Information technology division to establish a } \\
\text { monitoring system for quality of care, and a } \\
\text { patient database to support preventive care } \\
\text { guidelines and medical error alerts }\end{array}$} & $\begin{array}{l}\text { Administrative costs not to exceed } 5 \% \text { of Trust } \\
\text { income per year }\end{array}$ \\
\hline & Establishment of an enrollment system & & Planning division to determine resource \\
\hline & Patient choice of any participating providers & \multirow{2}{*}{$\begin{array}{l}\text { Quality assurance division to establish } \\
\text { standards for hospital staffing levels, clinical } \\
\text { practices, medical homes, end of life care }\end{array}$} & $\begin{array}{l}\text { allocation and capital expenaltures } \\
\text { Bulk nurchasing nower to negotiate nrices of }\end{array}$ \\
\hline & $\begin{array}{l}\text { Eligible providers may not provide services } \\
\text { covered but not paid for by the Trust }\end{array}$ & & medical supplies and pharmaceuticals \\
\hline & $\begin{array}{l}\text { No copayments, coinsurance, or } \\
\text { deductibles for covered services }\end{array}$ & \multirow{3}{*}{$\begin{array}{l}\text { Trust funds may be used to pay for prevention, } \\
\text { education, outreach and public health } \\
\text { programs }(\leq 5 \% \text { of Trust income per year); } \\
\text { health care workforce training and education } \\
(\leq 2 \%) \text {; and medical research and innovation } \\
(\leq 1 \%)\end{array}$} & \\
\hline & Substitutive insurance prohibited & & \\
\hline & $\begin{array}{l}\text { Quality assurance division to establish } \\
\text { standards for access to timely care }\end{array}$ & & \\
\hline & \multirow{2}{*}{$\begin{array}{l}\text { Planning division to conduct an annual } \\
\text { review of health care resources, particularly } \\
\text { for underserved populations and areas in } \\
\text { terms of provider supply and culturally and } \\
\text { linguistically appropriate care }\end{array}$} & \multirow{2}{*}{\multicolumn{2}{|c|}{$\begin{array}{l}\text { Information technology division to establish electronic medical record and electronic billing } \\
\text { systems } \\
\text { Early detection and intervention to avoid most expensive treatment in the future }\end{array}$}} \\
\hline & & & \\
\hline $\begin{array}{l}\text { An act } \\
\text { concerning a } \\
\text { single-payer } \\
\text { health care } \\
\text { system } \\
\text { (Connecticut, } \\
\text { SB 60, 2013) }\end{array}$ & $\mathrm{n} / \mathrm{a}$ & $\mathrm{n} / \mathrm{a}$ & $\mathrm{n} / \mathrm{a}$ \\
\hline \multirow{4}{*}{$\begin{array}{l}\text { An act to amend } \\
\text { the public health } \\
\text { law and the } \\
\text { state finance } \\
\text { law, in relation } \\
\text { to establishing } \\
\text { New York } \\
\text { Health (New } \\
\text { York, AB } \\
\text { 5389A, 2013) }\end{array}$} & $\begin{array}{l}\text { Coverage of all New York residents for a } \\
\text { comprehensive benefit package }\end{array}$ & \multirow{2}{*}{$\begin{array}{l}\text { Establishment of standards for health care } \\
\text { organizations, care coordinators, and health } \\
\text { care providers }\end{array}$} & $\begin{array}{l}\text { Establishment of provider payment } \\
\text { methodologies through demonstrations }\end{array}$ \\
\hline & $\begin{array}{l}\text { No premiums for enrollment no cost sharing } \\
\text { services covered by the program }\end{array}$ & & $\begin{array}{l}\text { Establishment of payment methodologies for } \\
\text { capital expenditures }\end{array}$ \\
\hline & $\begin{array}{l}\text { Employer-sponsored insurance not } \\
\text { prohibited, but no substitutive insurance } \\
\text { unless employees are out-of-state residents } \\
\text { or for retiree health insurance }\end{array}$ & \multirow[t]{2}{*}{$\begin{array}{l}\text { Payment for services only if beneficiary is } \\
\text { enrolled with a care coordinator, who } \\
\text { manages, refers, and coordinates services }\end{array}$} & \\
\hline & $\begin{array}{l}\text { Patient choice of any provider participating } \\
\text { in the program }\end{array}$ & & \\
\hline
\end{tabular}




\begin{tabular}{|c|c|c|c|}
\hline Proposal/Bill & Access & Quality & Cost \\
\hline \multirow{8}{*}{$\begin{array}{l}\text { Family and } \\
\text { Business } \\
\text { Healthcare } \\
\text { Security Act } \\
\text { (Pennsylvania, } \\
\text { SB 400, 2013) }\end{array}$} & $\begin{array}{l}\text { Coverage of all Pennsylvania residents for } \\
\text { a comprehensive benefit package }\end{array}$ & \multirow{4}{*}{$\begin{array}{l}\text { Establishment of four quality panels: Health } \\
\text { Professional Quality Panel, Health Institution } \\
\text { Quality Panel, Health Supplier Quality Panel, } \\
\text { Health Care Ombudsman Panel } \\
\text { Pennsylvania Health Care Board to determine } \\
\text { provider reimbursement at rates appropriate } \\
\text { for the provider skill, training, and costs and for } \\
\text { reasonable profit to maintain talent and capital } \\
\text { investment in the field }\end{array}$} & $\begin{array}{l}\text { Administrative expenditures not to exceed } 5 \% \\
\text { of overall budget }\end{array}$ \\
\hline & \multirow{2}{*}{$\begin{array}{l}\text { Establishment of an access card system as } \\
\text { proof of enrollment; ensure that enrollment } \\
\text { of those who travel often and have } \\
\text { language barriers }\end{array}$} & & \multirow{4}{*}{$\begin{array}{l}\text { Pennsylvania Health Care Board to approve } \\
\text { expenditures for facilities and other capital } \\
\text { Pennsylvania Health Care Board may limit } \\
\text { beneficiary choice of provider and set policies } \\
\text { for practices that over-utilize or underutilize } \\
\text { services if wasteful or outlier practices are } \\
\text { observed }\end{array}$} \\
\hline & & & \\
\hline & $\begin{array}{l}\text { Patient has free choice of providers; no } \\
\text { preapprovals or referrals needed for } \\
\text { specialists }\end{array}$ & & \\
\hline & \multirow{2}{*}{$\begin{array}{l}\text { No cost sharing for services by participating } \\
\text { providers; patient reimbursement for } \\
\text { services by nonparticipating providers and } \\
\text { out-of-state providers (according to the fee } \\
\text { schedule, patient responsible for costs } \\
\text { beyond the plan rate) }\end{array}$} & $\begin{array}{l}\text { Pennsylvania Health Care Board to conduct } \\
\text { an annual review of best practices for high } \\
\text { quality care }\end{array}$ & \\
\hline & & \multirow[t]{3}{*}{$\begin{array}{l}\text { Establishment of a standardized claims system } \\
\text { system }\end{array}$} & and a centralized electronic health record \\
\hline & No restrictions on private health insurance & & \\
\hline & $\begin{array}{l}\text { Pennsylvania Health Care Board to conduct } \\
\text { an annual evaluation of access to care }\end{array}$ & & \\
\hline \multirow{3}{*}{$\begin{array}{l}\text { Maryland Health } \\
\text { Benefit } \\
\text { Exchange - } \\
\text { Universal } \\
\text { Health Care } \\
\text { Program - Plan } \\
\text { for } \\
\text { Establishment } \\
\text { (Maryland, S } \\
667,2014 \text { ) }\end{array}$} & $\begin{array}{l}\text { Coverage of all Maryland residents for a } \\
\text { comprehensive benefit package }\end{array}$ & \multirow[t]{2}{*}{$\mathrm{n} / \mathrm{a}$} & $\begin{array}{l}\text { Establishment of provider payment } \\
\text { mechanisms such as global payments }\end{array}$ \\
\hline & \multirow{2}{*}{$\begin{array}{l}\text { Inclusion of dental, vision, hearing, and } \\
\text { long-term care services to be determined } \\
\text { based on future analysis conducted or } \\
\text { commissioned by the Board of Trustees of } \\
\text { the Maryland Health Benefit Exchange }\end{array}$} & & Reduction of administrative expenditures \\
\hline & & $\begin{array}{l}\text { Incentives provided to residents to promote } \\
\text { health and avoid preventable and unnecessary } \\
\text { health care }\end{array}$ & \\
\hline \multirow{2}{*}{$\begin{array}{l}\text { Delaware } \\
\text { Health Security } \\
\text { Act (Delaware, } \\
\text { HB 74, 2013) }\end{array}$} & Patient choice of provider & \multirow{2}{*}{$\begin{array}{l}\text { The Benefits Division of the Authority to } \\
\text { conduct annual review of the benefit package } \\
\text { The Quality Assurance Division of the } \\
\text { Authority to conduct an annual review of } \\
\text { quality and outcomes }\end{array}$} & Annual operating and capital budgets \\
\hline & $\begin{array}{l}\text { The Planning Division of the Delaware } \\
\text { Health Security Authority to coordinate } \\
\text { health care resources }\end{array}$ & & $\begin{array}{l}\text { The Authority to negotiate prescription drug } \\
\text { and other manufacturer discounts and rebates }\end{array}$ \\
\hline
\end{tabular}




\begin{tabular}{|c|c|c|c|}
\hline Proposal/Bill & Access & Quality & Cost \\
\hline \multirow{4}{*}{$\begin{array}{l}\text { An act to } \\
\text { provide for the } \\
\text { North Carolina } \\
\text { Health Plan to } \\
\text { cover all state } \\
\text { residents with } \\
\text { comprehensive } \\
\text { health benefit } \\
\text { coverage... } \\
\text { (North Carolina, } \\
\text { HB 70, 2013) }\end{array}$} & $\begin{array}{l}\text { Coverage of all North Carolina residents for } \\
\text { a comprehensive benefit package }\end{array}$ & \multirow[t]{3}{*}{$\mathrm{n} / \mathrm{a}$} & \multirow[t]{4}{*}{$\mathrm{n} / \mathrm{a}$} \\
\hline & Patient choice of provider & & \\
\hline & No cost sharing for the first two years; in & & \\
\hline & $\begin{array}{l}\text { later years, deductibles no greater than } \\
\$ 250 \text { per person and } \$ 500 \text { per family, and } \\
\text { no cost sharing for preventive care; cost } \\
\text { sharing may be charged for specialist care } \\
\text { without a referral from a primary care } \\
\text { provider }\end{array}$ & $\begin{array}{l}\text { Establishment of an electronic medical record sy } \\
\text { Benefits to include a prescription drug formulary }\end{array}$ & \\
\hline \multirow[t]{11}{*}{$\begin{array}{l}\text { Ohio Health } \\
\text { Security Act } \\
\text { (Ohio, SB 104 / } \\
\text { HB 121, 2013) }\end{array}$} & $\begin{array}{l}\text { Coverage of all Ohio residents for a } \\
\text { comprehensive benefit package } \\
\text { Establishment of an enrollment system that } \\
\text { is accessible to residents who do not speak }\end{array}$ & \multirow{2}{*}{$\begin{array}{l}\text { The administrator of quality assurance to } \\
\text { study the efficacy of treatments, develop } \\
\text { procedure to reduce medical errors, } \\
\text { determine whether treatments have no added } \\
\text { value, and assess provider and consumer } \\
\text { feedback on medical standards }\end{array}$} & $\begin{array}{l}\text { Annual budget with a limit on total } \\
\text { expenditures; separate budgets for the system, } \\
\text { providers, capital investments, purchasing, and } \\
\text { research and innovation }\end{array}$ \\
\hline & English, cannot read, and travel frequently & & $\begin{array}{l}\text { Administrative expenditures not to exceed } 5 \% \\
\text { of the total system budget }\end{array}$ \\
\hline & $\begin{array}{l}\text { No copayments or other cost sharing for } \\
\text { covered benefits }\end{array}$ & \multirow{3}{*}{$\begin{array}{l}\text { The technical and medical advisory board to } \\
\text { recommend the exclusion of treatments, } \\
\text { procedures, equipment, and prescription } \\
\text { drugs from covered benefits due to safety } \\
\text { reasons or lack of value; annual review of } \\
\text { benefit package }\end{array}$} & \multirow{4}{*}{$\begin{array}{l}\text { The Ohio health care board to set cost control } \\
\text { measures when expenditures exceed revenues } \\
\text { (actual or forecasted); measures may include } \\
\text { delay of new benefits, delay of new capital, } \\
\text { adjustment of provider budgets, provider } \\
\text { reimbursement global cap, pharmaceutical } \\
\text { manufacturers global cap, eligibility waiting } \\
\text { period }\end{array}$} \\
\hline & $\begin{array}{l}\text { Patient choice of providers participating in } \\
\text { the program }\end{array}$ & & \\
\hline & Substitutive insurance prohibited & & \\
\hline & \multirow{6}{*}{$\begin{array}{l}\text { The technical and medical advisory board } \\
\text { to establish incentives for providers in } \\
\text { underserved areas }\end{array}$} & $\begin{array}{l}\text { The Ohio health care board to establish a } \\
\text { quality and satisfaction monitoring system }\end{array}$ & \\
\hline & & \multirow{2}{*}{$\begin{array}{l}\text { Funds from the research and innovation } \\
\text { budget to be used to improve administration } \\
\text { and quality, patient education, and provider } \\
\text { communication }\end{array}$} & $\begin{array}{l}\text { Annual review of provider payment rates by the } \\
\text { Ohio health care board }\end{array}$ \\
\hline & & & \multirow[t]{2}{*}{$\begin{array}{l}\text { The administrator of finance to investigate } \\
\text { medical fraud }\end{array}$} \\
\hline & & $\begin{array}{l}\text { Funding to providers may be terminated if } \\
\text { standards established by the Ohio health care } \\
\text { board are not met }\end{array}$ & \\
\hline & & \multicolumn{2}{|c|}{ Establishment of an electronic claims and payments system } \\
\hline & & \multicolumn{2}{|c|}{ The administrator of quality assurance to establish a formulary } \\
\hline
\end{tabular}




\begin{tabular}{|c|c|c|c|}
\hline Proposal/Bill & Access & Quality & Cost \\
\hline \multirow{11}{*}{$\begin{array}{l}\text { Illinois Universal } \\
\text { Health Care Act } \\
\text { (Illinois, HB 942, } \\
\text { 2013) }\end{array}$} & \multirow{3}{*}{$\begin{array}{l}\text { Coverage of all individuals residing in } \\
\text { Illinois for a comprehensive benefit package } \\
\text { Individuals to apply for Illinois Health } \\
\text { Services Insurance cards; social security } \\
\text { numbers will not be used in registration }\end{array}$} & \multirow{3}{*}{$\begin{array}{l}\text { Health facilities to meet regional and state } \\
\text { quality, licensing, and safe staffing guidelines } \\
\text { The Illinois Health Services Governing Board } \\
\text { to make changes to the benefits package } \\
\text { based on evidence }\end{array}$} & Global budget and capital expenditure budgets \\
\hline & & & \multirow{2}{*}{$\begin{array}{l}\text { Administrative costs may not exceed } 12 \% \text { of } \\
\text { the total operating budget in the first } 2 \text { years, } \\
8 \% \text { in the next } 2 \text { years, and } 5 \% \text { in subsequent } \\
\text { years }\end{array}$} \\
\hline & & & \\
\hline & $\begin{array}{l}\text { Patient choice of any licensed provider; } \\
\text { providers may choose to participate in the } \\
\text { program entirely or not at all }\end{array}$ & & \multirow{2}{*}{$\begin{array}{l}\text { Global operating budgets for hospitals } \\
\text { negotiated annually; regional health planning } \\
\text { districts to allocate funds for capital } \\
\text { expenditures }\end{array}$} \\
\hline & \multirow{7}{*}{$\begin{array}{l}\text { No cost sharing for covered benefits unless } \\
\text { the Illinois Health Services Governing } \\
\text { Board determines that a good or service } \\
\text { exceeds the basic coverage } \\
\text { Substitutive insurance prohibited; } \\
\text { complementary insurance allowed }\end{array}$} & & \\
\hline & & & \multirow{2}{*}{$\begin{array}{l}\text { Providers may select their payment model: } \\
\text { fee-for-service from a negotiated schedule, } \\
\text { salaried in facilities with global budgets, or } \\
\text { salaried in group practices and health } \\
\text { maintenance organizations with capitation }\end{array}$} \\
\hline & & & \\
\hline & & & $\begin{array}{l}\text { The Pharmaceutical and Durable Medical } \\
\text { Goods Committee to negotiate prescription } \\
\text { drug and medical good prices and purchase in } \\
\text { bulk }\end{array}$ \\
\hline & & \multicolumn{2}{|c|}{ Establishment of electronic claims and billing within 5 years } \\
\hline & & \multicolumn{2}{|c|}{$\begin{array}{l}\text { Establishment of an electronic medical record system that is uniform throughout the state within } \\
7 \text { years }\end{array}$} \\
\hline & & \multicolumn{2}{|c|}{$\begin{array}{l}\text { Establishment of a formulary for prescription drugs and a list of durable medical supplies; lowest } \\
\text { cost therapeutically equivalent option should be used; the Pharmaceutical and Durable Medical } \\
\text { Goods Committee to review the formulary every quarter and modify as needed }\end{array}$} \\
\hline
\end{tabular}




\begin{tabular}{|c|c|c|c|}
\hline Proposal/Bill & Access & Quality & Cost \\
\hline \multirow{8}{*}{$\begin{array}{l}\text { An act... } \\
\text { relating to: } \\
\text { establishing a } \\
\text { publically } \\
\text { financed health } \\
\text { care system for } \\
\text { residents of this } \\
\text { state... } \\
\text { (Wisconsin, SB } \\
51,2007 \text { ) }\end{array}$} & \multicolumn{2}{|c|}{$\begin{array}{l}\text { The regional consumer health councils to monitor access to care, quality of care, and unmet } \\
\text { health care needs, and make recommendations for improvements }\end{array}$} & $\begin{array}{l}\text { Annual budgets for the overall system and for } \\
\text { operational costs, health facilities and } \\
\text { services, and provider payments }\end{array}$ \\
\hline & \multirow{3}{*}{$\begin{array}{l}\text { Coverage of all residents for a } \\
\text { comprehensive benefit package } \\
\text { Electronic identification cards for billing and } \\
\text { payment; social security numbers will not } \\
\text { be used as identification }\end{array}$} & \multirow[t]{5}{*}{$\mathrm{n} / \mathrm{a}$} & \multirow{2}{*}{$\begin{array}{l}\text { The board to review cost containment policies } \\
\text { and provide guidelines and recommendations } \\
\text { on a biennial basis }\end{array}$} \\
\hline & & & \\
\hline & & & \multirow{3}{*}{$\begin{array}{l}\text { Negotiated prices for medicines for the lowest } \\
\text { possible cost from manufacturers and } \\
\text { distributors; establishment of a single price for } \\
\text { each medicine }\end{array}$} \\
\hline & Patient choice of any participating provider & & \\
\hline & No cost sharing for covered benefits & & \\
\hline & $\begin{array}{l}\text { Periodic review of underserved areas and } \\
\text { populations and establishment of } \\
\text { community health centers and plans to } \\
\text { provide services to such areas }\end{array}$ & \multicolumn{2}{|c|}{ Establishment of a formulary of approved medicines } \\
\hline & \multicolumn{3}{|c|}{ The department of health planning and finance to establishment provider payment schedules, allowing for differences by regional and urbanity } \\
\hline
\end{tabular}




\begin{tabular}{|c|c|c|c|}
\hline Proposal/Bill & Access & Quality & Cost \\
\hline \multirow{12}{*}{$\begin{array}{l}\text { Minnesota } \\
\text { Health Plan } \\
\text { (Minnesota, HF } \\
76,2012 \text { ) }\end{array}$} & \multicolumn{2}{|c|}{$\begin{array}{l}\text { Establishment of an Ombudsman Office for Patient Advocacy to address public input and } \\
\text { complaints }\end{array}$} & $\begin{array}{l}\text { Operating, capital, and reserve accounts with } \\
\text { statewide and regional budgets }\end{array}$ \\
\hline & \multicolumn{2}{|c|}{ The board to ensure culturally and linguistically appropriate care } & \multirow{3}{*}{$\begin{array}{l}\text { Non-institutional provider payment rates } \\
\text { negotiated between the board and providers } \\
\text { (rates may be adjusted if there are provider } \\
\text { shortages); institutional providers to receive } \\
\text { annual operating and capital budgets }\end{array}$} \\
\hline & $\begin{array}{l}\text { Coverage of all Minnesota residents for a } \\
\text { comprehensive benefit package }\end{array}$ & $\begin{array}{l}\text { The board to implement quality assurance } \\
\text { measures }\end{array}$ & \\
\hline & \multirow{2}{*}{$\begin{array}{l}\text { Establishment of an enrollment system and } \\
\text { identification mechanism }\end{array}$} & \multirow{4}{*}{$\begin{array}{l}\text { Establishment of a health service research } \\
\text { account with funds for research and innovation }\end{array}$} & \\
\hline & & & The board to conduct fraud prevention \\
\hline & \multirow{2}{*}{$\begin{array}{l}\text { Patient choice of any participating provider; } \\
\text { all patients to have a primary care provider } \\
\text { and care coordination access; no referrals } \\
\text { needed for specialty care }\end{array}$} & & $\begin{array}{l}\text { procedures, and to implement cost } \\
\text { containment measures }\end{array}$ \\
\hline & & & $\begin{array}{l}\text { Establishment of an auditor general for fraud } \\
\text { and abuse }\end{array}$ \\
\hline & No cost sharing for covered benefits & \multicolumn{2}{|c|}{ Establishment of an electronic claims and payments system } \\
\hline & $\begin{array}{l}\text { Coverage for residents when out of state } \\
\text { temporarily; may establish reciprocal } \\
\text { coverage agreements with other states }\end{array}$ & \multirow{3}{*}{\multicolumn{2}{|c|}{$\begin{array}{l}\text { The board to conduct surveys and collect data to assess the benefit package, quality of } \\
\text { services, cost of services, and cost containment measures }\end{array}$}} \\
\hline & Substitutive insurance prohibited & & \\
\hline & $\begin{array}{l}\text { Establishment of rural health planning } \\
\text { regions and regional planning boards to } \\
\text { address priorities and guidelines for each } \\
\text { region }\end{array}$ & & \\
\hline & \multicolumn{3}{|c|}{ Establishment of an Office of Health Quality and Planning to assess and make recommendations on quality, access, and funding } \\
\hline
\end{tabular}




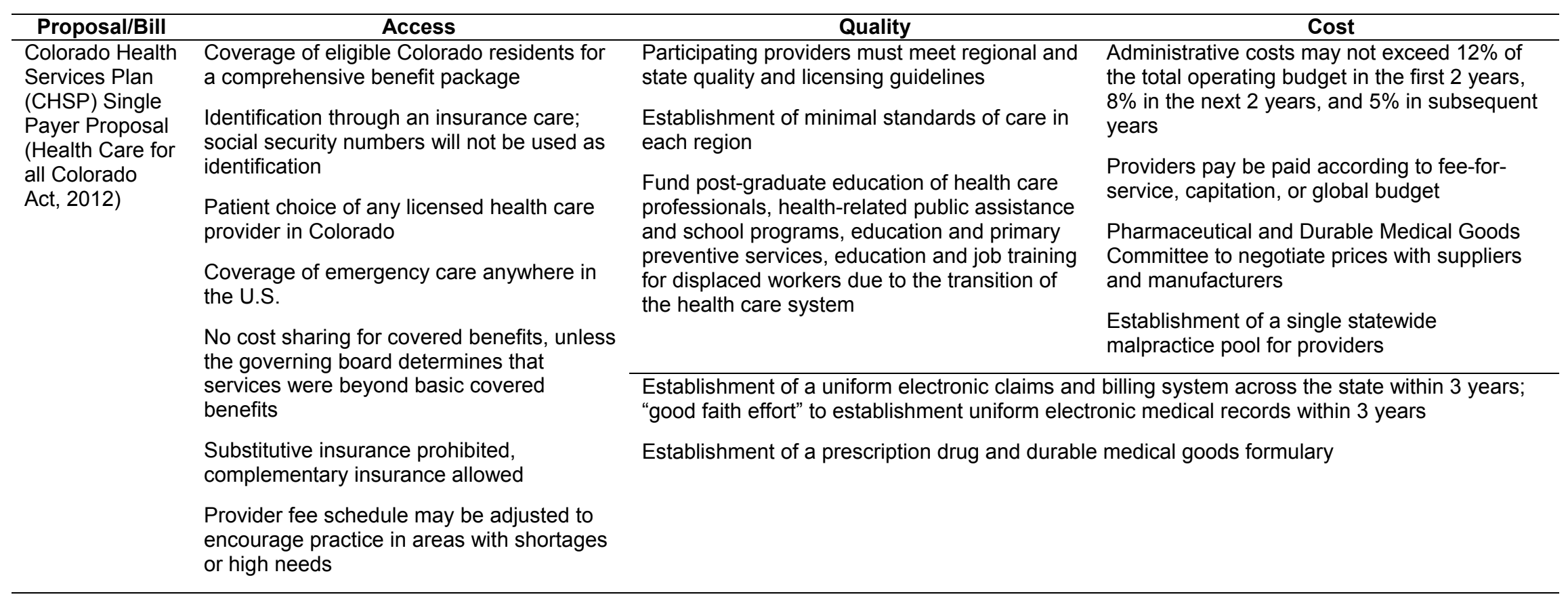




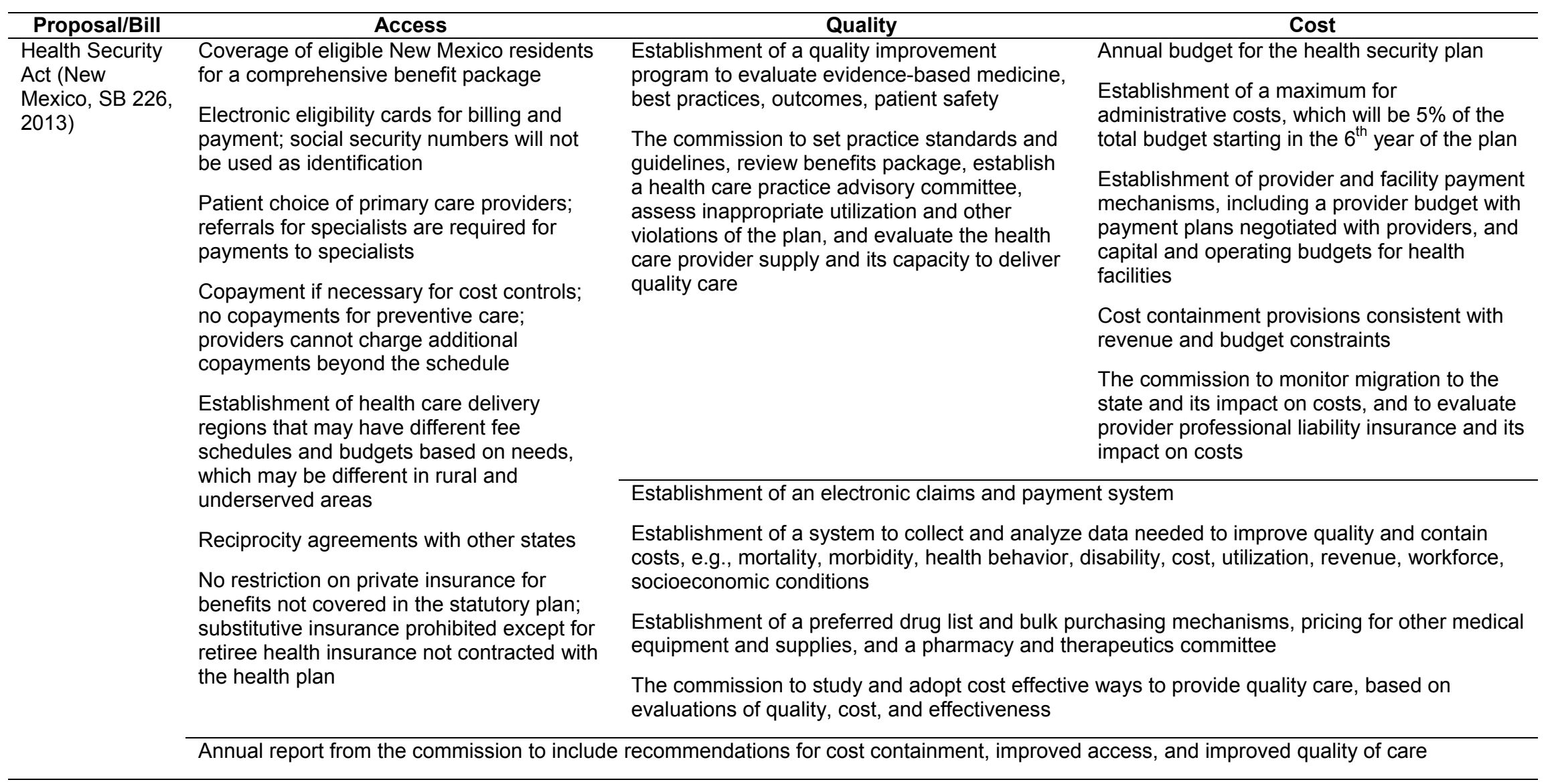




\begin{tabular}{|c|c|c|c|}
\hline Proposal/Bill & Access & Quality & Cost \\
\hline \multirow{15}{*}{$\begin{array}{l}\text { State Health } \\
\text { Plan (Arizona, } \\
\text { HB 2677, 2007) }\end{array}$} & Coverage of all residents for a & \multirow{10}{*}{$\begin{array}{l}\text { Establishment of a quality improvement } \\
\text { program to evaluate evidence-based medicine, } \\
\text { best practices, outcomes, patient safety } \\
\text { The commission to set practice standards and } \\
\text { guidelines, review benefits package, establish } \\
\text { a health care practice advisory committee, } \\
\text { assess inappropriate utilization and other } \\
\text { violations of the plan, and evaluate the health } \\
\text { care provider supply and its capacity to deliver } \\
\text { quality care }\end{array}$} & Annual budget for the health security plan \\
\hline & comprehensive benefit package & & Establishment of a maximum for \\
\hline & \multirow{3}{*}{$\begin{array}{l}\text { Electronic eligibility cards for billing and } \\
\text { payment; social security numbers will not } \\
\text { be used as identification }\end{array}$} & & administrative costs, which will be $5 \%$ of the \\
\hline & & & total budget starting in the $6^{\text {th }}$ year of the plan \\
\hline & & & Establishment of provider and facility payment \\
\hline & $\begin{array}{l}\text { Patient choice of primary care providers; } \\
\text { referrals for specialists are required for } \\
\text { payments to specialists }\end{array}$ & & $\begin{array}{l}\text { mechanisms, including a provider budget with } \\
\text { payment plans negotiated with providers, and } \\
\text { capital and operating budgets for health }\end{array}$ \\
\hline & \multirow{3}{*}{$\begin{array}{l}\text { Copayment if necessary for cost controls; } \\
\text { no copayments for preventive care; } \\
\text { providers cannot charge additional } \\
\text { copayments beyond the schedule }\end{array}$} & & 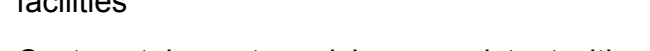 \\
\hline & & & $\begin{array}{l}\text { Cost containment provisions consistent with } \\
\text { revenue and budget constraints }\end{array}$ \\
\hline & & & The commission to monitor migration to the \\
\hline & \multirow{2}{*}{$\begin{array}{l}\text { Establishment of health care delivery } \\
\text { regions that may have different fee } \\
\text { schedules and budgets based on needs, } \\
\text { which may be different in rural and } \\
\text { underserved areas }\end{array}$} & & $\begin{array}{l}\text { state and its impact on costs, and to evaluate } \\
\text { provider professional liability insurance and its } \\
\text { impact on costs }\end{array}$ \\
\hline & & Establishment of an electronic claims and paym & nt system \\
\hline & \multirow{2}{*}{$\begin{array}{l}\text { No restriction on private insurance for } \\
\text { benefits not covered in the statutory plan; } \\
\text { substitutive insurance prohibited except for } \\
\text { retiree health insurance not contracted with } \\
\text { the health plan }\end{array}$} & \multicolumn{2}{|c|}{$\begin{array}{l}\text { Establishment of a system to collect and analyze data needed to improve quality and contain } \\
\text { costs, e.g., mortality, morbidity, health behavior, disability, cost, utilization, revenue, workforce, } \\
\text { socioeconomic conditions }\end{array}$} \\
\hline & & \multicolumn{2}{|c|}{$\begin{array}{l}\text { Establishment of a preferred drug list and bulk purchasing mechanisms, pricing for other medical } \\
\text { equipment and supplies, and a pharmacy and therapeutics committee }\end{array}$} \\
\hline & $\begin{array}{l}\text { Out-of-state health care may be reimbursed } \\
\text { at the same rate as in-state services }\end{array}$ & \multicolumn{2}{|c|}{$\begin{array}{l}\text { The commission to study and adopt cost effective ways to provide quality care, based on } \\
\text { evaluations of quality, cost, and effectiveness }\end{array}$} \\
\hline & 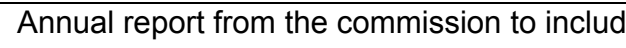 & nent, impro & ccess, and improvec \\
\hline
\end{tabular}




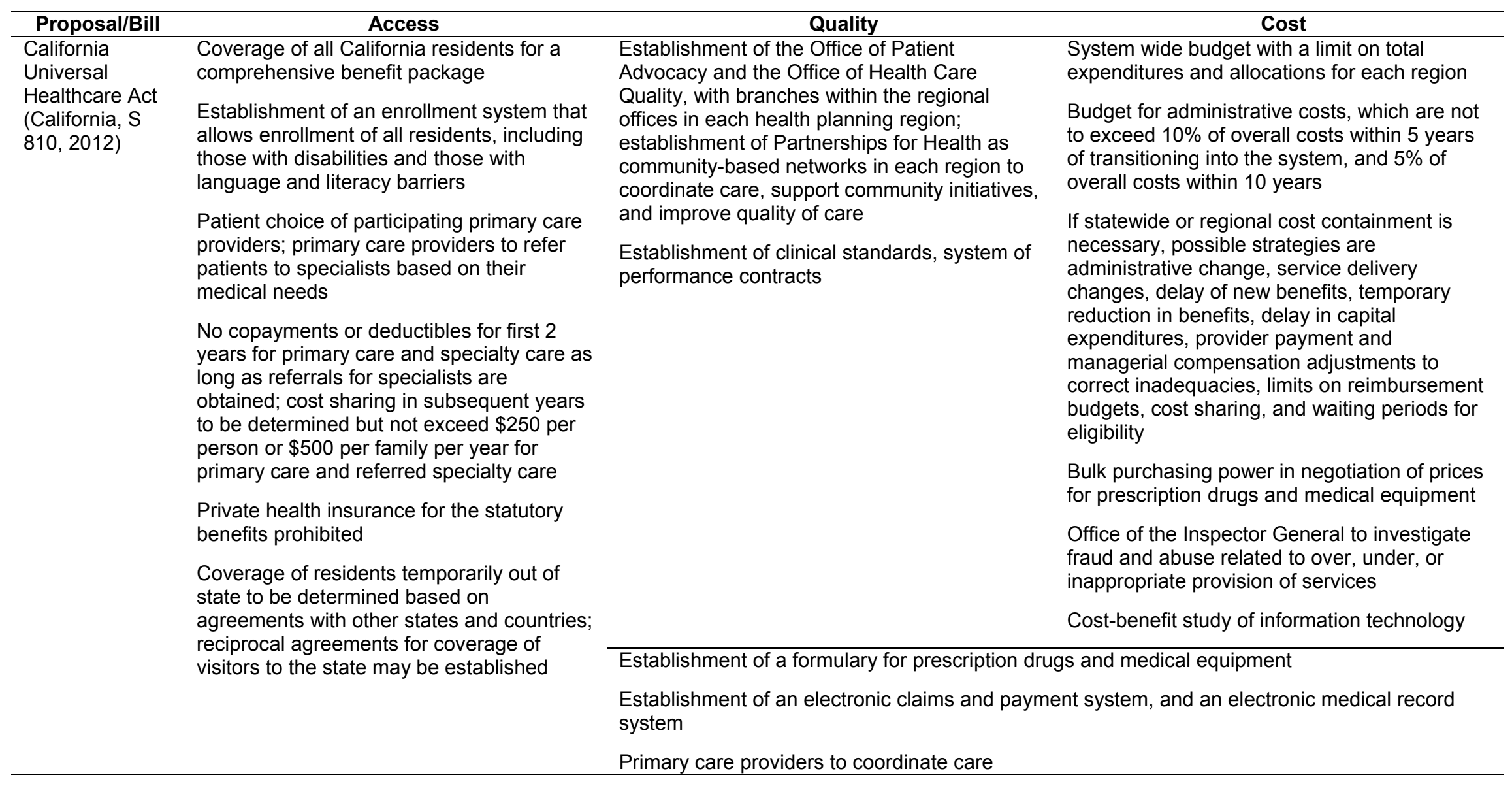




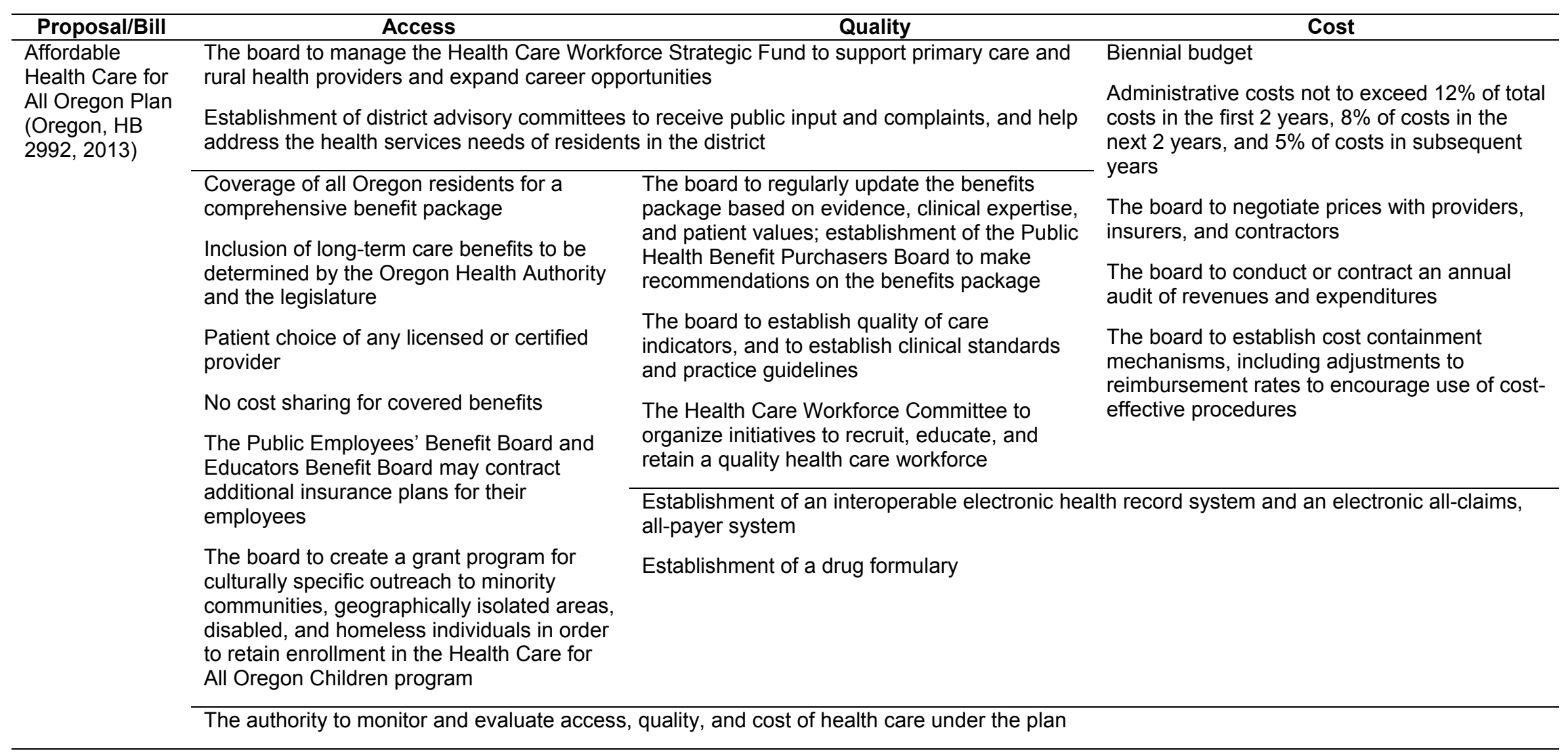




\begin{tabular}{|c|c|c|c|}
\hline Proposal/Bill & Access & Quality & Cost \\
\hline \multirow{10}{*}{$\begin{array}{l}\text { An act relating } \\
\text { to the } \\
\text { Washington } \\
\text { health security } \\
\text { trust } \\
\text { (Washington, } \\
\text { HB } 1085 \text { / SB } \\
5224,2013 \text { ) }\end{array}$} & \multicolumn{2}{|c|}{$\begin{array}{l}\text { Establishment of a citizens' advisory committee to assess public satisfaction, complaints, and } \\
\text { health care access }\end{array}$} & \multirow{2}{*}{$\begin{array}{l}\text { Annual budget } \\
\text { Administrative costs not to exceed } 11 \% \text { of the } \\
\text { annual budget }\end{array}$} \\
\hline & $\begin{array}{l}\text { Coverage of all Washington residents for a } \\
\text { comprehensive benefit package }\end{array}$ & \multirow{2}{*}{$\begin{array}{l}\text { Establishment of a technical advisory } \\
\text { committee to make recommendations on the } \\
\text { covered benefits, quality assurance, and } \\
\text { utilization }\end{array}$} & \\
\hline & \multirow{2}{*}{$\begin{array}{l}\text { Plans to include long-term care and dental } \\
\text { benefits to be developed by the board of } \\
\text { trustees, with consideration of financial } \\
\text { analysis }\end{array}$} & & $\begin{array}{l}\text { Establishment of a financial advisory } \\
\text { committee to make recommendations on } \\
\text { budgets, appropriations, and taxes }\end{array}$ \\
\hline & & $\begin{array}{l}\text { The board of trustees to establish practice } \\
\text { guidelines and quality standards }\end{array}$ & $\begin{array}{l}\text { The board of trustees to negotiate global } \\
\text { budgets with facilities and group practices }\end{array}$ \\
\hline & $\begin{array}{l}\text { Patient choice of any provider } \\
\text { Cost sharing for residents }>150 \% \text { FPL to be } \\
\text { determined by the board of trustees; annual } \\
\text { cap of } \$ 150 \text { per family }\end{array}$ & \multirow[t]{3}{*}{$\begin{array}{l}\text { The board of trustees to determine coverage of } \\
\text { medical research and health professions } \\
\text { training }\end{array}$} & $\begin{array}{l}\text { Individual providers to be paid fee-for- } \\
\text { services or salaried if employed by an } \\
\text { institution; the board of trustees to study } \\
\text { capitated payments for providers }\end{array}$ \\
\hline & $\begin{array}{l}\text { The board of trustees to determine } \\
\text { coverage for residents while temporarily out } \\
\text { of state }\end{array}$ & & $\begin{array}{l}\text { Pharmaceutical and durable medical } \\
\text { equipment manufacturers to offer lowest rate } \\
\text { offered to government entities }\end{array}$ \\
\hline & \multirow[t]{4}{*}{ Complementary insurance not prohibited } & & $\begin{array}{l}\text { The board of trustees to develop cost } \\
\text { containment measures as needed, and } \\
\text { annually report on health care costs }\end{array}$ \\
\hline & & \multirow{3}{*}{\multicolumn{2}{|c|}{$\begin{array}{l}\text { Establishment of a uniform claims processing system for provider payment } \\
\text { The board of trustees may establish drug formularies } \\
\text { Establishment of a statewide health data system to monitor quality and cost; the board of } \\
\text { trustees to determine cases of excessive utilization and fraud }\end{array}$}} \\
\hline & & & \\
\hline & & & \\
\hline \multirow{2}{*}{$\begin{array}{l}\text { A bill for an act } \\
\text { relating to } \\
\text { health care } \\
\text { (Hawaii, HB } \\
1617,2003)\end{array}$} & $\begin{array}{l}\text { Coverage of all Hawaii residents for } \\
\text { benefits allowed under Medicaid }\end{array}$ & \multirow{2}{*}{$\begin{array}{l}\text { The state health authority commission to review } \\
\text { all health benefits and determine coverage; } \\
\text { establishment of a review panel on mandated } \\
\text { health care service coverage }\end{array}$} & \multirow{2}{*}{$\begin{array}{l}\text { The state health authority commission to } \\
\text { determine financing costs, contribution } \\
\text { amounts, financial impact, social impact, and } \\
\text { medical impact of the program }\end{array}$} \\
\hline & $\begin{array}{l}\text { Health care coverage provided by the state } \\
\text { authority must be portable }\end{array}$ & & \\
\hline
\end{tabular}




\section{Appendix B: Technical Details of Modeling Assumptions}

\section{Firm Offers and Spending without the Tax Exclusion}

The tax treatment of employer-sponsored insurance (ESI) influences a firm's decision to offer ESI and how much to spend on premium contributions on behalf of their employees. The elimination of the ESI tax exclusion makes ESI less tax advantageous; however, a firm may choose to still offer ESI to workers without the tax exclusion in order to take advantage of pooling, negotiation, and administration within a large group.

I used published elasticities to adjust firms' decision to offer ESI and firm spending based on the tax price (Gruber and Lettau, 2004). The elasticity of firm offers with respect to tax price for small firms ( $<100$ workers) was -0.537 , while large firms' ( $\geq 100$ workers) decision to offer ESI would not be significantly affected by tax price. The elasticity of firm spending on ESI (employer premium contributions) with respect to tax price was -1.342 for small firms and -0.445 for large firms. In addition, I assumed firms would no longer offer ESI if the estimated firm spending resulted in health insurance benefits below $60 \%$ actuarial value (the minimum value for essential benefits under the ACA) due to reduced firm spending.

\section{Private Premium Calculation in Catastrophic Scenarios}

In the catastrophic scenarios allowing private insurance options, I assumed private insurance would be available to cover expenses below the catastrophic deductible (Figure B.1). I assumed that total revenue (person weight $w$ times premium $p$ ) equaled total claims paid (totexp minus оopexp) plus administrative costs and profits (admin):

$$
\sum w_{i} p_{i}=\sum w_{i}(\text { totexp }- \text { oopexp })_{i}(1+\text { admin })
$$


Figure B.1. Private Insurance Coverage below the Catastrophic Deductible

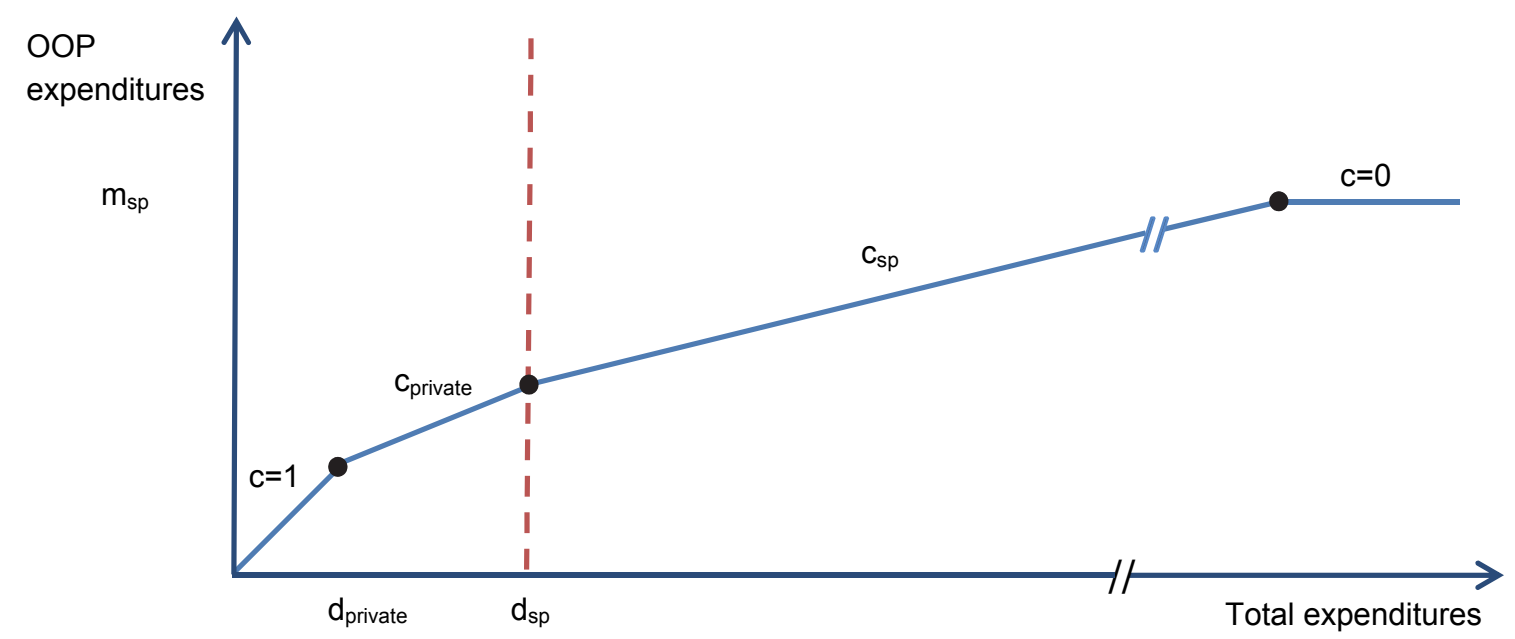

$\mathrm{OOP}=$ out-of-pocket, $d=$ deductible, $c=$ coinsurance, $m=$ maximum OOP, $s p=$ single-payer

I calculated household income rating $\left(f_{\text {inc }}\right)$ and age rating $\left(f_{\text {age }}\right)$ curves for each plan (Figures B.2 and B.3), in which the expected premiums were equal to the expected payout for each income and age group plus administrative costs. I assumed premiums were proportional to the income and age rating in each insurance pool $(\alpha)$ :

$$
p_{\text {inc,age, } \alpha}=r_{\alpha} f_{\text {inc }} f_{\text {age }}
$$

Substituting the premium and solving for the ratio (r) for each pool gives the following:

$$
r_{\alpha}=\frac{\sum_{\alpha} w_{\alpha}(\text { totexp }- \text { oopexp })_{\alpha}(1+\text { admin })}{\sum_{\alpha} w_{\alpha} * f_{\text {inc }} f_{\text {age }}}
$$

The group pools were separated by region and firm size. The non-group pools were separated by actuarial value $(60,70,80$, and $90 \%)$, smoking status, and age. Single and family premiums are calculated based on the ratio for the risk pool, family income, and age of the oldest family member. 
Figure B.2. Income Rating Curves

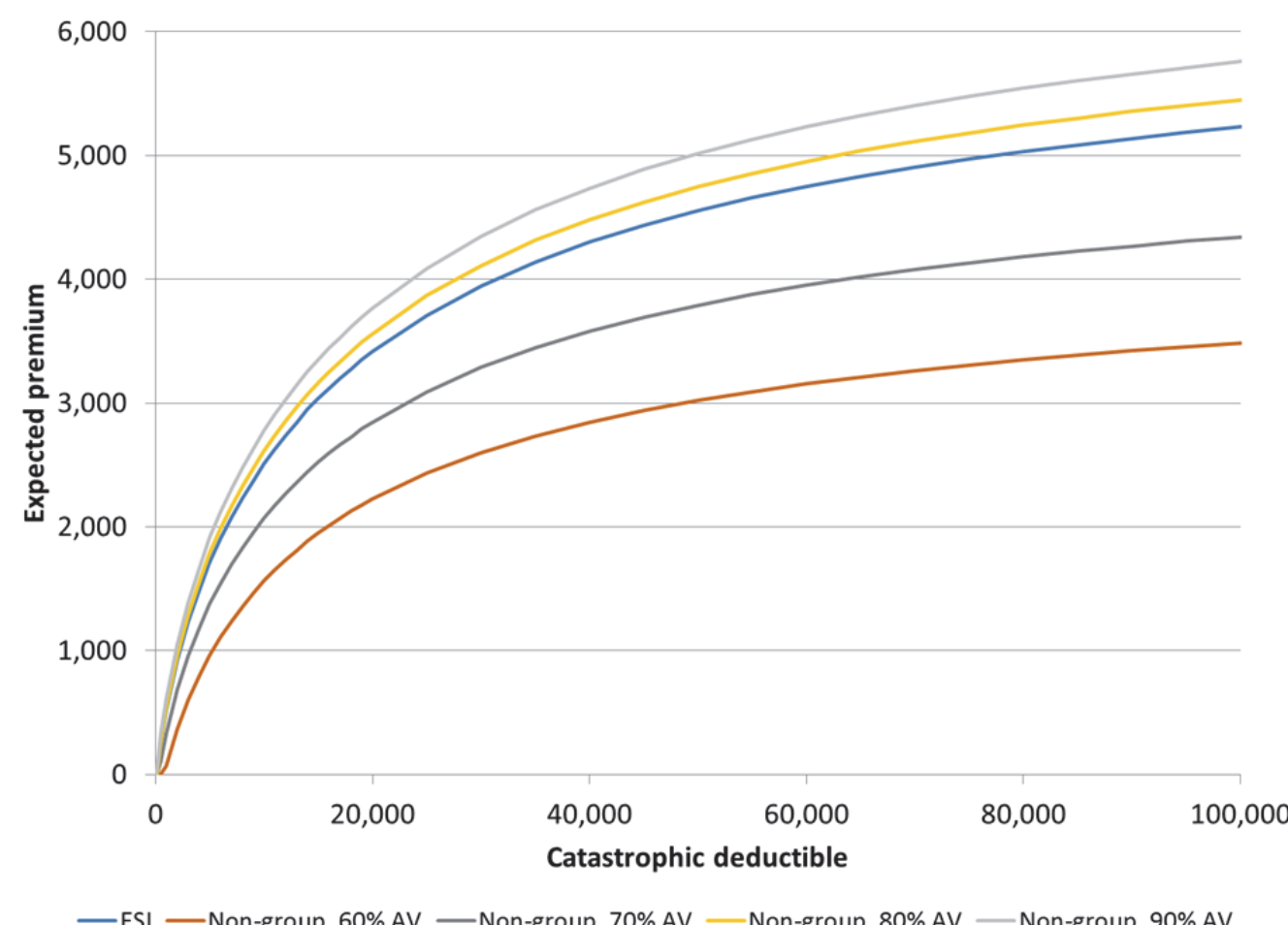

Figure B.3. Age Rating Curves

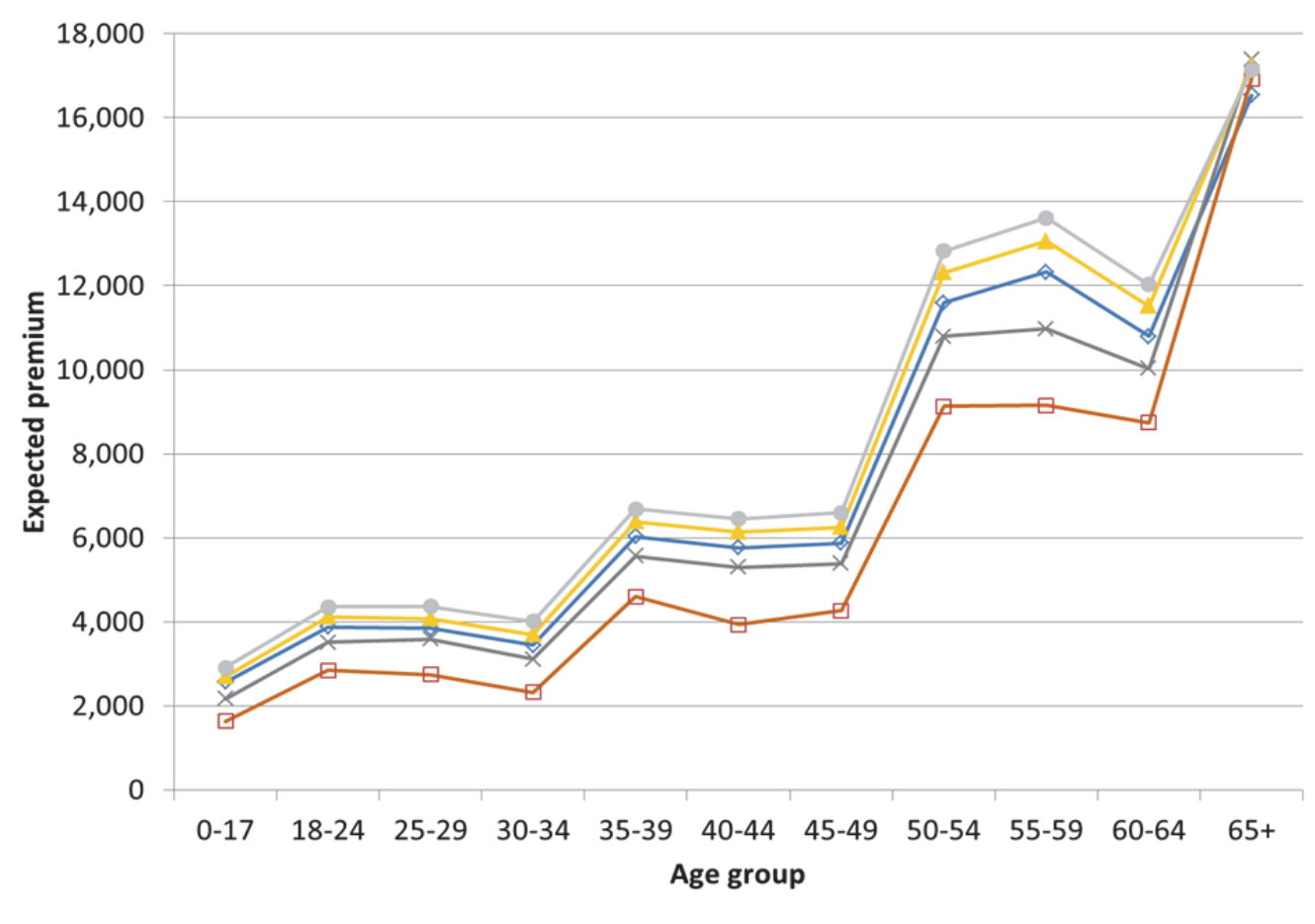

$\multimap$ ESI $\square$ Non-group, 60\% AV $\leftarrow$ Non-group, $70 \%$ AV $\multimap$ Non-group, 80\% AV $\multimap$ Non-group, 90\% AV 


\section{Existing Federal Income Taxes Supporting Health Care}

Income variables from the 2008 SIPP wave 6 core file were used to prepare the inputs to NBER's TAXSIM model. I adjusted top-coded earned income upwards to match wages and salaries projected by the CBO, $\$ 8.5$ trillion in 2017 (Congressional Budget Office, 2015a). I assigned the primary taxpayer as the household member with the highest personal total income. Total property (asset) income and interest income were included as other property income. I calculated other non-taxable transfer income as total means-tested cash transfers and other income minus Social Security benefits and unemployment compensation, which were included as separate inputs to TAXSIM.

To estimate the share of federal income taxes used to fund health care under current policies, I assumed the share was proportional to the share of federal outlays on health care programs:

Share of federal income tax payments supporting health care

$$
=\frac{\text { (total federal health care outlays)-(net Medicare Part A outlays) }}{\text { (total federal outlays)-(net Social Security outlays)-(net Medicare Part A outlays) }}
$$

Medicare Part A and Social Security outlays were excluded from outlays funded by federal income taxes because they are funded by trust funds financed by dedicated payroll taxes.

In 2017, total outlays on Medicare, Medicaid, the Children's Health Insurance Program (CHIP), and exchange subsidies and other spending were projected to be $\$ 967$ billion (Congressional Budget Office, 2014c). Total outlays for Veterans health care, defense health programs, and other health programs will be $\$ 230$ billion (White House Office of Management and Budget, 2014). I assumed the share of defense health spending for military retirees will be equal to the proportion of retirees and their families among active service members and retirees, 54\% in 2012 (Congressional Budget Office, 2014a). Defense health spending for active services members was excluded because I assumed total compensation for active service members would 
rise if health spending was reduced, resulting in no change in the share of federal income taxes supporting health care. Total federal outlays were projected to be $\$ 4.1$ trillion, and net Social Security outlays will be $\$ 971$ billion (Congressional Budget Office, 2014c). Net Medicare Part A outlays will be $\$ 306$ billion (Congressional Budget Office, 2013). Based on these outlay projections, I estimated that $34 \%$ of federal income taxes would be used to support health care.

\section{Single-Payer Income Tax Schedule}

The income tax schedule proposed in the American Health Security Act (S. 1782, 113th Congress) is as follows:

Single return (2015 dollars)

$2.2 \%$ if taxable income $\leq \$ 200,000$

$\$ 4,400+3.2 \%$ of the excess over $\$ 200,000$ if taxable income $>\$ 200,000$ and $\leq \$ 400,000$

$\$ 10,800+4.2 \%$ of the excess over $\$ 400,000$ if taxable income $>\$ 400,000$ and $\leq \$ 600,000$

$\$ 19,200+5.2 \%$ of the excess over $\$ 600,000$ if taxable income $>\$ 600,000$

$5.4 \%$ surcharge on modified adjusted gross income $>\$ 500,000$

Joint return (2015 dollars)

$2.2 \%$ if taxable income $\leq \$ 250,000$

$\$ 5,500+3.2 \%$ of the excess over $\$ 250,000$ if taxable income $>\$ 250,000$ and $\leq \$ 400,000$

$\$ 10,300+4.2 \%$ of the excess over $\$ 400,000$ if taxable income $>\$ 400,000$ and $\leq \$ 600,000$

$\$ 18,700+5.2 \%$ of the excess over $\$ 600,000$ if taxable income $>\$ 600,000$

$5.4 \%$ surcharge on modified adjusted gross income $>\$ 1,000,000$

The above amounts are to be adjusted for inflation in each year after 2015 and rounded down to the thousands place. Using the consumer price index to inflate the dollar amounts, I estimated the following schedule for 2017 :

Single return (2017 dollars)

$2.2 \%$ if taxable income $\leq \$ 207,000$

$\$ 4,500+3.2 \%$ of the excess over $\$ 207,000$ if taxable income $>\$ 207,000$ and $\leq \$ 415,000$

$\$ 11,200+4.2 \%$ of the excess over $\$ 415,000$ if taxable income $>\$ 415,000$ and $\leq \$ 623,000$

$\$ 19,900+5.2 \%$ of the excess over $\$ 623,000$ if taxable income $>\$ 623,000$

$5.4 \%$ surcharge on modified adjusted gross income $>\$ 519,000$ 
Joint return (2017 dollars)

$2.2 \%$ if taxable income $\leq \$ 259,000$

$\$ 5,700+3.2 \%$ of the excess over $\$ 259,000$ if taxable income $>\$ 250,000$ and $\leq \$ 415,000$

$\$ 10,600+4.2 \%$ of the excess over $\$ 415,000$ if taxable income $>\$ 415,000$ and $\leq \$ 623,000$

$\$ 19,400+5.2 \%$ of the excess over $\$ 623,000$ if taxable income $>\$ 623,000$

$5.4 \%$ surcharge on modified adjusted gross income $>\$ 1,038,000$

\section{Trading Volume Assumption with the Single-Payer Securities Transaction Tax}

The single-payer securities transaction tax was based on the fair market value of the security. I calculated the total securities transaction tax revenue using the 2013 transaction volumes of equities, options, futures deliveries (U.S. Securities and Exchange Commission, 2015), and bonds (Securities Industry and Financial Markets Association, 2015), and an assumed reduction in trading volume due to the imposition of the tax. Others have assumed trading volume reductions ranging from 0 to 50\% (Keightley, 2012; Pollin, Baker and Schaberg, 2002; Schulmeister, Schratzenstaller and Picek, 2008), and estimates of the elasticity of trading volume with respect to transaction costs have ranged from -1.5 to -0.5 (Matheson, 2011; McCulloch, 2011). An average initial transaction cost of $0.25 \%$ (Matheson, 2012; Pollin and Heintz, 2011) and an upper elasticity estimate of -1.5 translates to a $12 \%$ reduction in trading volume. For a more conservative estimate of potential revenues from a $0.02 \%$ securities transaction tax, I assumed a $25 \%$ reduction in trading volume, resulting in $\$ 40$ billion in tax revenue, which is similar to a $\mathrm{CBO}$ projection of $\$ 19$ billion with a $0.01 \%$ tax on securities transactions (Congressional Budget Office, 2013). 


\section{Appendix C: Alternative Comprehensive Single-Payer Scenario}

Estimated health care expenditures in an alternative comprehensive single-payer scenario based on the Expanded \& Improved Medicare For All Act (H.R. 676, $114^{\text {th }}$ Congress) were compared to estimates in the base comprehensive scenario based on the American Health Security Act. The Medicare For All Act is similar to the American Health Security Act in that it provides comprehensive coverage with no cost sharing for covered services. The acts differ in the level of administration: the American Health Security Act would be administered at the state or regional level, while the Medicare For All Act would be federally administered. Although the implementation of these acts would be different, the level of administration does not affect the modeling of health care spending presented here.

Table C. 1 shows the alternative comprehensive scenario (Comp-Alt). As in the base comprehensive scenario, all citizens and legal residents would be eligible for a $98 \%$ AV singlepayer plan. While the types of taxes in the alternative comprehensive scenario are based on the Medicare For All Act, the act does not specify the tax levels. For this scenario, tax levels were set to be similar to the American Health Security Act and a prior analysis of the Medicare For All Act (Friedman, 2013). The unearned income tax was applied to dividend income, property income, interest income, pension distributions, Social Security benefits, unemployment compensation, and supplemental unemployment benefits. 
Table C.1. Alternative Comprehensive Scenario

\begin{tabular}{|c|c|c|}
\hline & \multicolumn{2}{|c|}{ Comprehensive Single-Payer } \\
\hline & Comp-Base & Comp-Alt \\
\hline Proposal & $\begin{array}{l}\text { Based on the American Health Security } \\
\text { Act (S. 1782, 113th Congress) }\end{array}$ & $\begin{array}{l}\text { Based on the Medicare For All Act } \\
\text { (H.R. 676, 114th Congress) }\end{array}$ \\
\hline Eligibility & \multicolumn{2}{|c|}{ Available to all U.S. citizens and legal residents } \\
\hline Plan Design & \multicolumn{2}{|c|}{$\begin{array}{l}\text { Uniform coverage with limited cost sharing } \\
98 \% \text { actuarial value } \\
\text { Private insurance duplicating single-payer coverage prohibited }\end{array}$} \\
\hline $\begin{array}{l}\text { Financing } \\
\text { Design }\end{array}$ & $\begin{array}{l}\text { Graduated income tax from } 2.2 \% \text { to } \\
5.2 \% \text {, plus } 5.4 \% \text { surcharge for high } \\
\text { earners } \\
6.7 \% \text { payroll tax paid by employers } \\
0.02 \% \text { securities transaction tax }\end{array}$ & $\begin{array}{l}6 \% \text { income tax for top } 5 \% \text { earners } \\
6 \% \text { unearned income tax } \\
3.35 \% \text { payroll tax on income }<\$ 50,000 \text {, } \\
6.7 \% \text { payroll tax on income } \geq \$ 50,000 \text {, } \\
\text { paid by employers } \\
0.02 \% \text { securities transaction tax }\end{array}$ \\
\hline
\end{tabular}

$\mathrm{AV}=$ actuarial value

NOTES: Health insurance plans can be designed in different ways and have the same AV. The comprehensive scenarios with $98 \% \mathrm{AV}$ were modeled using a plan with a zero deductible, $2.5 \%$ coinsurance, and $\$ 2,000$ OOP maximum.

The alternative comprehensive scenario resulted in similar health care expenditures as the base comprehensive scenario (Figure C.1), with a shortfall of over $\$ 1$ trillion in federal expenditures relative to the ACA (Table C.2). The distribution of average household spending on health care follows a similar trend as the trend in the base comprehensive scenario (Figure C.2). 


\section{Figure C.1. National Health Care Spending by Source of Revenue in 2017: Alternative}

Comprehensive Scenario

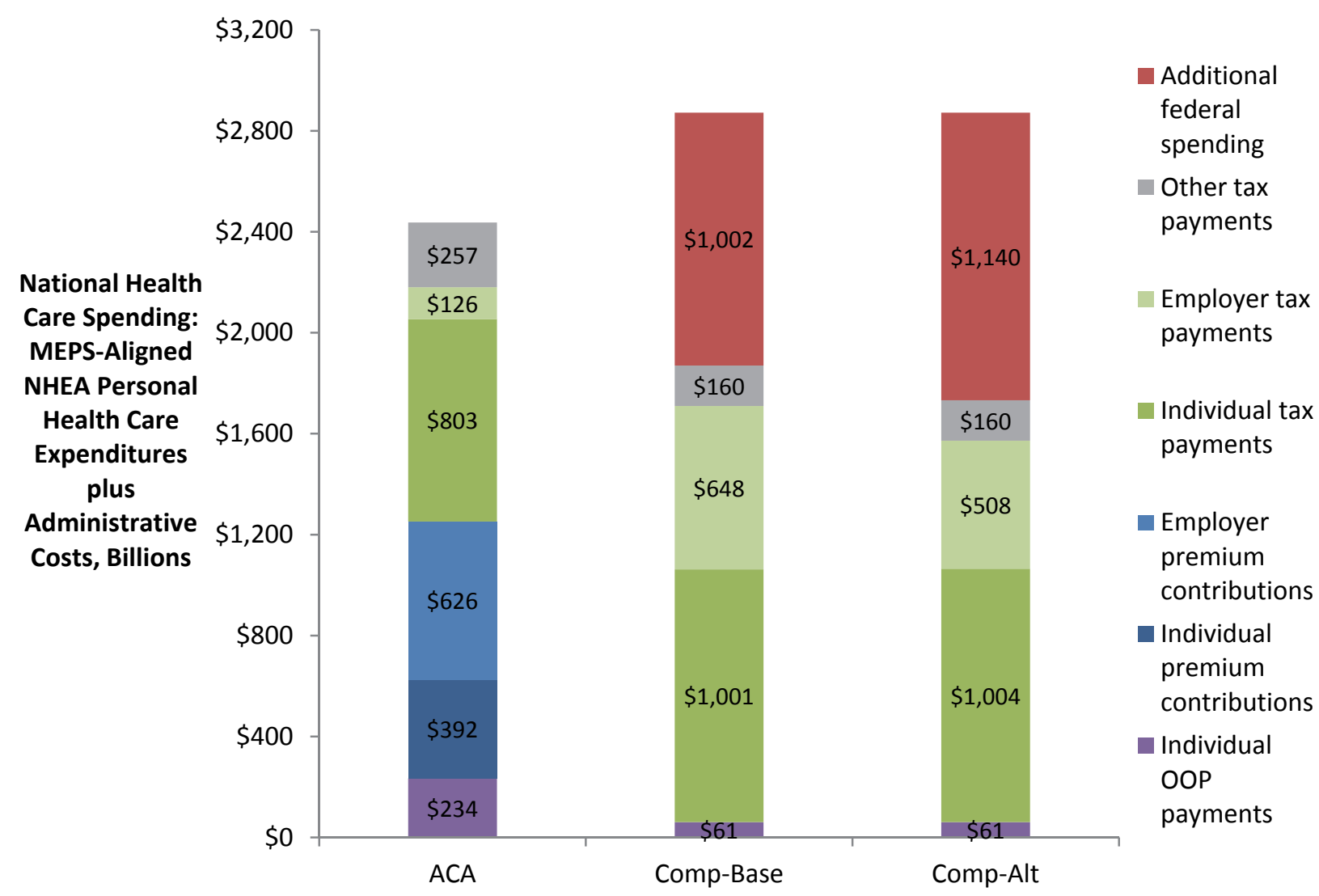

NOTES: The expenditures are the MEPS-aligned NHEA Personal Health Care Expenditures plus administrative costs. The effect of cost sharing on spending is included, but additional savings and costs associated with singlepayer systems are not included here. Sources of revenue in the form of out-of-pocket payments, premium contributions, and tax payments are overlaid on spending. Other tax payments include taxes such as corporate income taxes, excise taxes, estate and gift taxes, and state sales taxes. The additional federal spending represents the gap between projected spending and revenue sources. 
Table C.2. Federal Health Care Spending in 2017: Alternative Comprehensive Scenario

\begin{tabular}{lrrr}
\hline & ACA & Comp-Base & Comp-Alt \\
\hline Spending (\$ billions) & 707 & - & - \\
Medicare & 203 & - & - \\
Medicaid & 42 & - & - \\
Military & 72 & - & - \\
Exchange & - & 2,457 & 2,457 \\
Single-payer & 70 & 35 & 35 \\
Uninsured & 39 & 319 & 319 \\
Government administration & 1,133 & 2,811 & 2,811 \\
& & & \\
Revenue (\$ billions) & 594 & 604 & 612 \\
Income tax supporting health care & 261 & 266 & 270 \\
Medicare payroll tax & 17 & - & - \\
Penalty payments & - & 778 & 629 \\
Single-payer taxes & 160 & 160 & 160 \\
Other taxes supporting health care & 100 & - & - \\
Medicare premiums & 1 & - & - \\
TRICARE premiums & 1,133 & 1,810 & 1,672 \\
& & & 1,140 \\
\hline Net federal spending relative to ACA & - & 1,002 & - \\
\hline
\end{tabular}

NOTES: The effect of cost sharing on spending is included, but additional savings and costs associated with singlepayer systems are not included here. Other tax payments include taxes such as corporate income taxes, excise taxes, and estate and gift taxes. 
Figure C.2. Average Household Spending on Health Care in 2017: Alternative Comprehensive Scenario

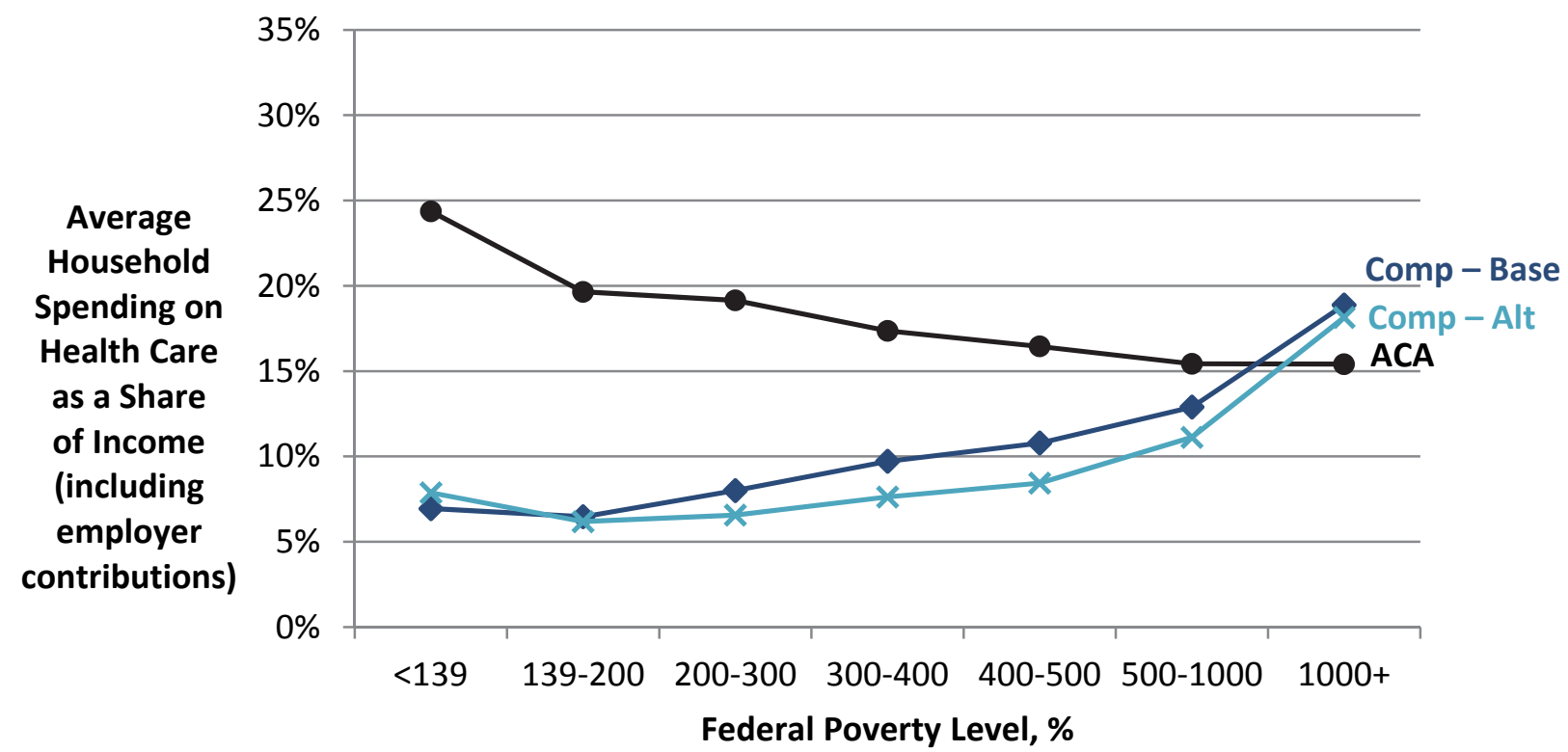

NOTES: In the numerator of spending as a share of income, household spending on health care includes premiums (paid by individuals and employers), out-of-pocket payments, federal income taxes devoted to health care programs, penalty payments (ACA), state income taxes devoted to Medicaid, Medicare payroll tax, single-payer taxes, and the value of the ESI tax exclusion. The income denominator includes household income plus employer premium contributions for health care benefits. I estimated the FPL to be $\$ 12,409$ for a single individual and $\$ 25,359$ for a family of four in 2017, based on the 2014 Department of Health and Human Services (HHS) poverty guidelines and inflated using the consumer price index estimated by the Congressional Budget Office (CBO). 


\section{Appendix D: Employer Spending}

Employer spending on health care is shown in Table D.1. Overall, firms spent about the same or less on average than they did under the ACA. However, firms that did not offer insurance under the ACA would pay much more under the comprehensive scenarios with mandatory payroll taxes. Employer spending in the base catastrophic scenario reflects the Medicare Hospital Insurance payroll tax. In other catastrophic scenarios, firms could offer insurance for expenditures below each employee's catastrophic deductible. In the catastrophic scenario without the ESI tax exclusion, only large firms with 100 or more employees offered insurance.

Table D.1. Employer Spending on Health Care in 2017

\begin{tabular}{|c|c|c|c|c|c|}
\hline \multicolumn{6}{|c|}{ Average employer spending per employee, \$ } \\
\hline & ACA & Comp & Cata-Base & Cata-Priv Ins & Cata-No Excl \\
\hline \multicolumn{6}{|l|}{ All firms } \\
\hline 1-24 employees & 3,000 & 2,750 & 520 & 1,230 & 520 \\
\hline 25-99 employees & 4,050 & 3,910 & 730 & 1,810 & 730 \\
\hline $100+$ employees & 5,650 & 4,860 & 910 & 2,400 & 2,540 \\
\hline \multicolumn{6}{|l|}{ Firms offering in ACA } \\
\hline 1-24 employees & 3,000 & 3,020 & 570 & 1,650 & 560 \\
\hline 25-99 employees & 4,050 & 3,980 & 740 & 2,070 & 740 \\
\hline 100+ employees & 5,650 & 4,870 & 920 & 2,430 & 2,570 \\
\hline \multicolumn{6}{|c|}{ Firms not offering in ACA } \\
\hline 1-24 employees & 430 & 2,230 & 430 & 460 & 430 \\
\hline 25-99 employees & 710 & 3,460 & 710 & 760 & 710 \\
\hline $100+$ employees & 340 & 2,940 & 340 & 520 & 570 \\
\hline
\end{tabular}




\section{References}

2011 Vt. Acts \& Resolves 48. An act relating to a universal and unified health system.

A. 5389A, 2013-2014 Gen. Assem., Reg. Sess. (N.Y. 2013).

Aaron, Henry J., "The costs of health care administration in the United States and Canada -

Questionable answers to a questionable question," New England Journal of Medicine, Vol. 349, No. 8, Aug 21, 2003, pp. 801-803.

American Health Security Act of 2013, S. 1782, 113th Cong., 1st Sess. (2013).

American Health Security Act of 2015, H.R. 1200, 114th Cong., 1st Sess. (2015).

Angrisano, Carlos, Diana Farrell, Bob Kocher, Martha Laboissiere, and Sara Parker, Accounting for the cost of health care in the United States, McKinsey Global Institute, 2007. As of October 23, 2014:

http://www.mckinsey.com/insights/health_systems_and_services/accounting_for_the_cost_o f_health_care_in_the_united_states

Aron-Dine, Aviva, Liran Einav, and Amy Finkelstein, "The RAND Health Insurance Experiment, three decades later," Journal of Economic Perspectives, Vol. 27, No. 1, Win, 2013, pp. 197-222.

Artiga, Samantha, Anthony Damico, Katherine Young, Elizabeth Cornachione, and Rachel Garfield, Health coverage and care for immigrants, Menlo Park, CA: Kaiser Family Foundation, 2016. As of April 27, 2016: http://kff.org/disparities-policy/issue-brief/healthcoverage-and-care-for-immigrants/

Atherly, Adam, "The effect of Medicare supplemental insurance on Medicare expenditures," International Journal of Health Care Finance and Economics, Vol. 2, No. 2, Jun, 2002, pp. 137-162.

Auerbach, David I., Sarah A. Nowak, Jeanne S. Ringel, Federico Girosi, Christine Eibner, Elizabeth A. McGlynn, and Jeffrey Wasserman, How will health care reform affect costs and coverage?, Santa Monica, CA: RAND Corporation, RB-9589, 2011. As of November 29, 2015: http://www.rand.org/pubs/research_briefs/RB9589.html

Baker, Dean, "Reducing waste with an efficient Medicare prescription drug benefit," 2013. As of March 6, 2016: http://cepr.net/documents/publications/medicare-drug-2012-12.pdf

Beeuwkes Buntin, Melinda, Amelia M. Haviland, Roland McDevitt, and Neeraj Sood, "Healthcare spending and preventive care in high-deductible and consumer-directed health plans," American Journal of Managed Care, Vol. 17, No. 3, Mar, 2011, pp. 222-230.

Bernard, Didem, Cathy Cowan, Thomas Selden, Liming Cai, Aaron Catlin, and Stephen Heffler, "Reconciling medical expenditure estimates from the MEPS and NHEA, 2007," Medicare \& Medicaid Research Review, Vol. 2, No. 4, 2012.

Bernard, Didem, Thomas M. Selden, and Yuriy O. Pylypchuk, Aligning the Medical Expenditure Panel Survey to aggregate U.S. benchmarks, 2010, Agency for Healthcare Research and 
Quality, No. 15002, 2015. As of April 15, 2015:

http://meps.ahrq.gov/mepsweb/data_files/publications/workingpapers/wp_15002.pdf

Berwick, Donald M., Thomas W. Nolan, and John Whittington, "The Triple Aim: Care, health, and cost," Health Affairs, Vol. 27, No. 3, May-Jun, 2008, pp. 759-769.

Blanchfield, Bonnie B., James L. Heffernan, Bradford Osgood, Rosemary R. Sheehan, and Gregg S. Meyer, "Saving billions of dollars - and physicians' time - by streamlining billing practices," Health Affairs, Vol. 29, No. 6, 2010, pp. 1248-1254.

Blewett, Lynn A., "Persistent disparities in access to care across health care systems," Journal of Health Politics, Policy and Law, Vol. 34, No. 4, Aug, 2009, pp. 635-647.

Blumenthal, David, "Employer-sponsored health insurance in the United States--origins and implications," New England Journal of Medicine, Vol. 355, No. 1, Jul 6, 2006, pp. 82-88.

Blumenthal, David, and Sara R. Collins, "Health care coverage under the Affordable Care Act--a progress report," New England Journal of Medicine, Vol. 371, No. 3, Jul 17, 2014, pp. 275281.

Brook, Robert H., John E. Ware, William H. Rogers, Emmett B. Keeler, Allyson R. Davies, Cathy A. Sherbourne, Geroge A. Goldberg, Kathleen N. Lohr, Patricia Camp, and Joseph P. Newhouse, The effect of coinsurance on the health of adults: Results from the RAND Health Insurance Experiment, Santa Monica, CA: RAND Corporation, R-3055-HHS, 1984. As of December 7, 2014: http://www.rand.org/pubs/reports/R3055.html

Buettgens, Matthew, Health Insurance Policy Simulation Model (HIPSM) methodology documentation, Washington, DC: Urban Institute, 2011. As of March 17, 2016:

http://www.urban.org/research/publication/health-insurance-policy-simulation-model-hipsmmethodology-documentation

Calfee, John E., "Pharmaceutical price controls and patient welfare," Annals of Internal Medicine, Vol. 134, No. 11, Jun 5, 2001, pp. 1060-1064.

Carman, Katherine G., and Christine Eibner, Changes in health insurance enrollment since 2012: Evidence from the RAND Health Reform Opinion Study, Santa Monica, CA: RAND Corporation, RR-656, 2014. As of June 5, 2015: http://www.rand.org/pubs/research_reports/RR656.html

Centers for Medicare \& Medicaid Services, Department of Health and Human Services, Medicaid \& CHIP: December 2015 monthly applications, eligibility determinations and enrollment report, Washington, DC, March 4, 2016a. As of May 9, 2016: http://www.medicaid.gov/medicaid-chip-program-information/programinformation/downloads/december-2015-enrollment-report.pdf

_ _ ,CMS program statistics," 2016b. As of May 8, 2016: http://www.cms.gov/ResearchStatistics-Data-and-Systems/Statistics-Trends-and-Reports/CMSProgramStatistics/

Chen, Alice, and Darius N. Lakdawalla, Savings lives or saving money? Understanding the dual nature of physician preferences, Cambridge, MA: National Bureau of Economic Research, Working Paper 21930, 2016. As of February 2, 2016: http://www.nber.org/papers/w21930

Collins, Sara R., Petra W. Rasmussen, and Michelle M. Doty, Gaining ground: Americans' health insurnace coverage and access to care after the Affordable Care Act's first open enrollment period, The Commonwealth Fund, 2014. As of December 7, 2014: 
http://www.commonwealthfund.org/publications/issue-briefs/2014/jul/Health-CoverageAccess-ACA

Committee for a Responsible Federal Budget, "Analysis of the Sanders single-payer offsets," February 3, 2016. As of February 12, 2016: http://fiscalfactcheck.crfb.org/analysis-of-thesanders-single-payer-offsets/s

Congressional Budget Office, A detailed description of $C B O$ 's cost estimate for the Medicare prescription drug benefit, Washington, DC, July, 2004. As of March 7, 2016:

http://www.cbo.gov/sites/default/files/108th-congress-2003-2004/reports/07-21-medicare.pdf

- CBO's Health Insurance Simulation Model: A technical description, Washington, DC, 2007. As of March 17, 2016:

http://www.cbo.gov/sites/default/files/cbofiles/ftpdocs/87xx/doc8712/10-31-

healthinsurmodel.pdf

, Options for reducing the deficit: 2014 to 2023, Washington, DC, 2013. As of September 16, 2015: http://www.cbo.gov/sites/default/files/cbofiles/attachments/44715-

OptionsForReducingDeficit-3.pdf

- Approaches to reducing federal spending on military health care, Washington, DC, 2014a. As of August 11, 2015: http://www.cbo.gov/sites/default/files/113th-congress-20132014/reports/44993-MilitaryHealthcare.pdf

, Comparing the costs of the veterans' health care system with private-sector costs, Washington, DC, December, 2014b. As of March 16, 2016:

http://www.cbo.gov/sites/default/files/113th-congress-2013-2014/reports/49763-

VA_Healthcare_Costs.pdf

, Updated estimates of the effects of the insurance coverage provisions of the Affordable Care Act, Washington, DC, 2014c. As of June 22, 2015:

http://www.cbo.gov/sites/default/files/45231-ACA_Estimates.pdf

- The budget and economic outlook: 2015 to 2025, Washington, DC, 2015a. As of October 14, 2015: http://www.cbo.gov/publication/49892

- Budgetary and economic effects of repealing the Affordable Care Act, Washington, DC, 2015b. As of June 26, 2015: http://www.cbo.gov/sites/default/files/114th-congress-20152016/reports/50252-Effects_of_ACA_Repeal.pdf

- Insurance coverage provisions of the Affordable Care Act-CBO's March 2015 baseline, Washington, DC, March 9, 2015c. As of June 22, 2015: http://www.cbo.gov/sites/default/files/cbofiles/attachments/43900-2015-03-ACAtables.pdf

Cordova, Amado, Federico Girosi, Sarah Nowak, Christine Eibner, and Kenneth Finegold, "The COMPARE microsimulation model and the U.S. Affordable Care Act," International Journal of Microsimulation, Vol. 6, No. 3, 2013, pp. 78-117.

Corlette, Sabrina, JoAnn Volk, Robert Berenson, and Judy Feder, Narrow provider networks in new health plans: balancing affordability with access to quality care, Washington DC: Georgetown University Center on Health Insurance Reforms, The Urban Institute, 2014. As of October 23, 2014:

http://www.rwjf.org/content/dam/farm/reports/issue_briefs/2014/rwjf413643 
Cubanski, Juliette, and Tricia Neuman, Searching for savings in Medicare drug price negotiations, Menlo Park, CA: Kaiser Family Foundation, 2016. As of April 15, 2016: $\mathrm{http} / / / \mathrm{kff}$.org/medicare/issue-brief/searching-for-savings-in-medicare-drug-pricenegotiations/

Cubanski, Juliette, Christina Swoope, Cristina Boccuti, Gretchen Jacobson, Giselle Casillas, Shannon Griffin, and Tricia Neuman, A primer on Medicare: key facts about the Medicare program and the people it covers, Kaiser Family Foundation, 2015. As of March 22, 2016: $\mathrm{http} / / \mathrm{kff}$.org/report-section/a-primer-on-medicare-what-types-of-supplemental-insurance-dobeneficiaries-have/

Deber, Raisa B., "Health care reform: Lessons from Canada," American Journal of Public Health, Vol. 93, No. 1, Jan, 2003, pp. 20-24.

DesRoches, Catherine M., Eric G. Campbell, Christine Vogeli, Jie Zheng, Sowmya R. Rao, Alexandra E. Shields, Karen Donelan, Sara Rosenbaum, Steffanie J. Bristol, and Ashish K. Jha, "Electronic health records' limited successes suggest more targeted uses," Health Affairs, Vol. 29, No. 4, Apr, 2010, pp. 639-646.

DiJulio, Bianca, Jamie Firth, Ashley Kirzinger, and Mollyann Brodie, Kaiser Health Tracking Poll: February 2016, Menlo Park, CA: Kaiser Family Foundation, 2016. As of April 17, 2016: http://kff.org/global-health-policy/poll-finding/kaiser-health-tracking-poll-february2016/

Eibner, Christine, Sarah A. Nowak, Jodi L. Liu, and Chapin White, The economic incidence of health care spending in Vermont, Santa Monica, CA: RAND Corporation, RR-901-SVJFO, 2015. As of March 1, 2016: http://www.rand.org/pubs/research_reports/RR901.html

Eibner, Christine, and Evan Saltzman, Assessing alternative modifications to the Affordable Care Act, Santa Monica, CA: RAND Corporation, RR-708, 2014. As of November 29, 2015: http://www.rand.org/pubs/research_reports/RR708.html

Emanuel, Ezekiel J., "The problem with single-payer plans," Hastings Center Report, Vol. 38, No. 1, Jan-Feb, 2008, pp. 38-41. As of May 29, 2014: http://www.jstor.org/stable/25165292

European Observatory on Health Systems and Policies, "Health Systems in Transition (HiT) series," edited by Busse, Reinhard, Josep Figueras, Martin McKee, Elias Mossialos, Sarah Thomson, and Ewout van Ginneken, 2014. As of October 20, 2014: http://www.euro.who.int/en/about-us/partners/observatory/health-systems-in-transition-hitseries

Expanded \& Improved Medicare For All Act, H.R. 676, 113th Cong., 1st Sess. (2013).

Expanded \& Improved Medicare For All Act, H.R. 676, 114th Cong., 1st Sess. (2015).

Finegold, Kenneth., "Microsimulation and the Affordable Care Act: An executive branch perspective," AcademyHealth Annual Research Meeting, San Diego, CA, 2014. As of July 7, 2015: http://www.academyhealth.org/files/2014/monday/finegold.pdf

Flood, Colleen M., and Amanda Haugan, "Is Canada odd? A comparison of European and Canadian approaches to choice and regulation of the public/private divide in health care," Health Economics, Policy and Law, Vol. 5, No. 3, Jul, 2010, pp. 319-341. 
Flood, Colleen M., and Terrence Sullivan, "Supreme disagreement: the highest court affirms an empty right," Canadian Medical Association Journal, Vol. 173, No. 2, Jul 19, 2005, pp. 142143.

Foster, Richard S., Estimated financial effects of the "America's Affordable Health Choices Act of 2009" (H.R. 3200), as reported by the Ways and Means Committee Centers for Medicare and Medicaid Services, Office of the Actuary, 2009. As of March 7, 2016: http://www.cms.gov/Research-Statistics-Data-andSystems/Research/ActuarialStudies/Downloads/HR3200_2009-10-21.pdf

Fox, Ashley. M., and Nathan J. Blanchet, "The Little State That Couldn't Could? The Politics of "Single-Payer" Health Coverage in Vermont," Journal of Health Politics, Policy and Law, Vol. 40, No. 3, Jun, 2015, pp. 447-485.

Frakt, Austin, "How Medicare solves private plans' problems and vice versa," 2012. As of February 28, 2016: http://newsatjama.jama.com/2012/06/21/jama-forum-how-medicaresolves-private-plans-problems-and-vice-versa/

Friedberg, Mark W., Peggy G. Chen, Chapin White, Olivia Jung, Laura Raaen, Samuel Hirshman, Emily Hoch, Clare Stevens, Paul B. Ginsburg, Lawrence P. Casalino, Michael Tutty, Carol Vargo, and Lisa Lipinski, Effects of health care payment models on physician practice in the United States, Santa Monica, CA: RAND Corporation, RR-869-AMA, 2015. As of March 22, 2016: http://www.rand.org/pubs/research_reports/RR869.html

Friedman, Gerald, Funding HR 676: The Expanded and Improved Medicare for All Act: how we can afford a national single-payer health plan, Physicians for a National Health Program, 2013. As of May 23, 2014:

http://www.pnhp.org/sites/default/files/Funding\%20HR\%20676_Friedman_7.31.13_proofed. pdf

, "United States can afford single payer health care program," January 17, 2016a. As of February 12, 2016: http://berniesanders.com/wp-content/uploads/2016/01/friedman-memo1.pdf

, "Where Kenneth Thorpe went wrong," February 5, 2016b. As of February 12, 2016: http://dollarsandsense.org/Friedman-response-to-Thorpe-paper-020516.pdf

Gagnon, Marc-Andre, and Sidney Wolfe, Mirror, mirror on the wall: Medicare Part D pays needlessly high brand-name drug prices compared with other OECD countries and with U.S. government programs, Carlton University and Public Citizen, July, 2015. As of March 7, 2016: http://carleton.ca/sppa/wp-content/uploads/Mirror-Mirror-Medicare-Part-DReleased.pdf

Garfield, Rachel, Rachel Licata, and Katherine Young, The uninsured at the starting line: findings from the 2013 Kaiser survey of low-income Americans and the ACA, Kaiser Family Foundation, February, 2014, 2014. As of October 20, 2014: $\mathrm{http}: / \mathrm{kff}$.org/uninsured/report/the-uninsured-at-the-starting-line-findings-from-the-2013kaiser-survey-of-low-income-americans-and-the-aca/

General Accounting Office, Canadian health insurance: Lessons for the United States, Washington, DC, 1991. As of February 13, 2015: http://archive.gao.gov/d20t9/144039.pdf

Glied, Sherry, "Single payer as a financing mechanism," Journal of Health Politics, Policy and Law, Vol. 34, No. 4, Aug, 2009, pp. 593-615. 
Golberstein, Ezra, Kayo Walsh, Yulei He, and Michael E. Chernew, "Supplemental coverage associated with more rapid spending growth for Medicare beneficiaries," Health Affairs, Vol. 32, No. 5, May, 2013, pp. 873-881.

Goss, Stephen, Alice Wade, J. Patrick Skirvin, Michael Morris, K. Mark Bye, and Danielle Huston, Effects of authorized immigration on the actuarial status of the Social Secruity Trust Funds, Baltimore, MD: Social Security Administration, Office of the Chief Actuary, 151, 2013. As of March 6, 2016: http://www.ssa.gov/oact/NOTES/pdf_notes/note151.pdf

Gruber, Jonathan, "Health insurance and the labor market," Handbook of health economics, Amsterdam: North-Holland, 2000, pp. 645-706.

, Proposal 3: Restructuring cost sharing and supplemental insurance for Medicare, Brookings Institute, The Hamilton Project, 2013. As of December 17, 2014 :

http://www.brookings.edu/research/papers/2013/02/medicare-cost-sharing-supplementalinsurance

- The impacts of the Affordable Care Act: How reasonable are the projections?, National Bureau of Economic Research, Working Paper 17168, 2011. As of March 25, 2016: http://www.nber.org/papers/w17168.pdf

Gruber, Jonathan, and Michael Lettau, "How elastic is the firm's demand for health insurance?," Journal of Public Economics, Vol. 88, No. 7-8, Jul, 2004, pp. 1273-1293.

Grumbach, Kevin, Thomas Bodenheimer, David U. Himmelstein, and Steffie Woolhandler, "Liberal benefits, conservative spending. The Physicians for a National Health Program proposal," Journal of the American Medical Association, Vol. 265, No. 19, May 15, 1991, pp. 2549-2554.

H.B. 2677, 48th Leg., 1st Reg. Sess. (Ariz. 2007).

H.B. 74, 147th Gen. Assems. (Del. 2013).

H.B. 942, 98th Gen. Assem. (Ill. 2013).

H.B. 1085 / S.B. 5224, 63rd Leg., Reg. Sess. (Wash. 2013).

H.B. 2992, 77th Leg., Reg. Sess. (Or. 2013).

H.F. 76, 2012 Leg., 88th Sess. (Minn. 2012).

H.P. 962, 126th Leg., 1st Reg. Sess. (Me. 2013).

Hagopian, Kip, and Dana Goldman, "The Health-Insurance Solution," National Affairs, Vol. 13, 2012, pp. 95-111.

Hanel, Joe, Amy Downs, Brian Clark, Cliff Foster, Deb Goeken, Michele Lueck, Allie Morgan, Nina Roumell, and Rebecca Silvernale, ColoradoCare: An independent analysis, Denver, CO: Colorado Health Institute, 2016. As of May 27, 2016:

http://www.coloradohealthinstitute.org/key-issues/detail/legislation-and-policy/coloradocarean-independent-analysis

Harrison, Bridget, "A historical survey of national health movements and public opinion in the United States," Journal of the American Medical Association, Vol. 289, No. 9, 2003, pp. 1163-1164. 
Hellman, Matthew S., Matthew E. Price, Julie Straus Harris, and Previn Warren, "Brief amici curiae for bipartisan economic scholars in support of respondents," Washington, DC: Jenner \& Block LLP, 2015. As of November 29, 2015:

https://jenner.com/system/assets/assets/8464/original/14-

114_20bsac_20Bipartisan_20Economic_20Scholars.pdf

Hillestad, Richard, James Bigelow, Anthony Bower, Federico Girosi, Robin Meili, Richard Scoville, and Roger Taylor, "Can electronic medical record systems transform health care? Potential health benefits, savings, and costs," Health Affairs, Vol. 24, No. 5, Sep-Oct, 2005, pp. 1103-1117.

Himmelstein, David U., Miraya Jun, Reinhard Busse, Karine Chevreul, Alexander Geissler, Patrick Jeurissen, Sarah Thomson, Marie-Amelie Vinet, and Steffie Woolhandler, "A comparison of hospital administrative costs in eight nations: US costs exceed all others by far," Health Affairs, Vol. 33, No. 9, Sep, 2014, pp. 1586-1594.

Hogan, Christopher, Exploring the effects of secondary coverage on Medicare spending for the elderly, Washington, DC: Direct Research, LLC, 2014. As of December 18, 2014:

http://medpac.gov/documents/contractorreports/Jun09_SecondaryInsurance_CONTRACTOR_RS_REVISED.pdf

Holahan, John, Lisa Clemans-Cope, Matthew Buettgens, Melissa Favreault, Linda J. Blumberg, and Siyabonga Ndwandwe, The Sanders single-payer health care plan, Washington, DC: Urban Institute, 2016. As of May 24, 2016:

http://www.urban.org/research/publication/sanders-single-payer-health-care-plan-effectnational-health-expenditures-and-federal-and-private-spending

Hsiao, William C., Anna G. Knight, Steven Kappel, and Nicolae Done, "What other states can learn from Vermont's bold experiment: Embracing a single-payer health care financing system," Health Affairs, Vol. 30, No. 7, Jul, 2011, pp. 1232-1241.

Hsiao, William, Steven Kappel, and Jonathan Gruber, "Act 128: Health system reform design. achieving affordable universal health care in Vermont," Final Report to the Vermont Legislature (February 19, 2011), 2011.

Hussey, Peter, and Gerald F. Anderson, "A comparison of single- and multi-payer health insurance systems and options for reform," Health Policy, Vol. 66, No. 3, Dec, 2003, pp. 215-228.

Institute of Medicine, Committee on Health Insurance Status and Its Consequences, America's uninsured crisis: Consequences for health and health care, Washington, DC: National Academy Press, 2009. As of May 2, 2016: http://www.nationalacademies.org/hmd/Reports/2009/Americas-Uninsured-CrisisConsequences-for-Health-and-Health-Care.aspx

Institute of Medicine, Committee on the Consequences of Uninsurance, Insuring America's health: Principles and recommendations, Washington, DC: National Academies Press, 2004. As of May 2, 2016: http://www.nationalacademies.org/hmd/Reports/2004/InsuringAmericas-Health-Principles-and-Recommendations.aspx

Jacobson, Gretchen, Jennifer Huang, and Tricia Neuman, Medigap reform: Setting the context for understanding recent proposals, Kaiser Family Foundation, 2014. As of December 17, 2014: http://kff.org/medicare/issue-brief/medigap-reform-setting-the-context/ 
Jiwani, Aliya, David Himmelstein, Steffie Woolhandler, and James G. Kahn, "Billing and insurance-related administrative costs in United States' health care: synthesis of microcosting evidence," BMC Health Services Research, Vol. 14, 2014, p. 556.

Kaiser Family Foundation, National health insurance - a brief history of reform efforts in the U.S., 2009. As of June 16, 2014: http://kff.org/health-reform/issue-brief/national-healthinsurance-a-brief-history-of/

_ 2015: http://kff.org/other/state-indicator/distribution-of-general-fund-spending/

-, Key facts about the uninsured population, Menlo Park, CA, 2015. As of April 8, 2015: http://kff.org/uninsured/fact-sheet/key-facts-about-the-uninsured-population/

Keightley, Mark P., A securities transaction tax: financial markets and revenue effects, Washington, DC: Congressional Research Service, R41192, 2012.

Kulesher, Robert R., and Elizabeth Forrestal, "International models of health systems financing," Journal of Hospital Administration, Vol. 3, No. 4, 2014, p. p127.

Kutzin, Joseph, "A descriptive framework for country-level analysis of health care financing arrangements," Health Policy, Vol. 56, No. 3, Jun, 2001, pp. 171-204.

Lameire, Norbert, Preben Joffe, and M. Wiedemann, "Healthcare systems--an international review: An overview," Nephrology, Dialysis, Transplantation, Vol. 14 Suppl 6, 1999, pp. 39.

Leibowitz, Arleen, "Fringe benefits in employee compensation," The Measurement of Labor Cost: University of Chicago Press, 1983, pp. 371-394.

Lewin Group, The Health Benefits Simulation Model (HBSM): Methodology and assumptions, Falls Church, VA, 2009. As of January 13, 2015:

http://www.lewin.com/ /media/Lewin/Site_Sections/Clients/HBSMSummary.pdf

London, Katherine, Michael Grenier, Robert Seifert, Thomas Friedman, Julie Peper, Julia Lambert, David Neiman, and Crystal Bradley, State of Vermont health care financing plan beginning calendar year 2017 analysis, Charlestown, MA: University of Massachusetts Medical School, Wakely Consulting Group, Inc., 2013.

Lu, Jui-Fen R., and Tung-Liang Chiang, "Evolution of Taiwan's health care system," Health Economics, Policy and Law, Vol. 6, No. 1, Jan, 2011, pp. 85-107.

Manning, Willard G, Joseph P Newhouse, Naihua Duan, Emmett B Keeler, and Arleen Leibowitz, "Health insurance and the demand for medical care: Evidence from a randomized experiment," Amer Econ Rev, Vol. 77, No. 3, 1987, pp. 251-277.

Manski, Charles F., Public policy in an uncertain world: analysis and decisions: Harvard University Press, 2013.

Martinez, Michael E., and Robin A. Cohen, Health insurance coverage: Early release of estimates from the National Health Interview Survey, January-June 2014, National Center for Health Statistics, December 2014. As of December 17, 2014: http://www.cdc.gov/nchs/data/nhis/earlyrelease/insur201412.pdf 
Matheson, Thornton, Taxing financial transactions: Issues and evidence, International Monetary Fund, 54, 2011. As of September 10, 2015:

http://www.imf.org/external/pubs/ft/wp/2011/wp1154.pdf

_ Vol. 19, No. 6, Dec, 2012, pp. 884-912.

McArdle, Frank; Stark, Ian; Levinson, Zachary; Neuman, Tricia, How does the benefit value of Medicare compare to the benefit value of typical large employer plans? A 2012 update, Kaiser Family Foundation, 2012. As of March 6, 2016: http://kaiserfamilyfoundation.files.wordpress.com/2013/01/7768-02.pdf

McCulloch, Neil; Pacillo, Grazia, The Tobin tax: A review of the evidence, Institute of Development Studies, 68, 2011. As of September 13, 2015: http://www.ids.ac.uk/publication/the-tobin-tax-a-review-of-the-evidence

McDonough, John E., "Wyden's waiver: State innovation on steroids," Journal of Health Politics, Policy and Law, Vol. 39, No. 5, Oct, 2014, pp. 1099-1111.

, "The demise of Vermont's single-payer plan," New England Journal of Medicine, Vol. 372, No. 17, Apr 23, 2015, pp. 1584-1585.

Medicare Trustees, 2014 annual report of the Board of Trustees of the Federal Hospital Insurance and Federal Supplementary Medical Insurance Trust Funds, 2014. As of December 18, 2014: http://www.cms.gov/Research-Statistics-Data-and-Systems/StatisticsTrends-and-Reports/ReportsTrustFunds/Downloads/TR2014.pdf

Morone, James A., "Presidents and health reform: From Franklin D. Roosevelt to Barack Obama," Health Affairs, Vol. 29, No. 6, Jun, 2010, pp. 1096-1100.

Mossialos, Elias, and Sarah Thomson, Voluntary health insurance in the European Union, Brussels: European Observatory on Health Systems and Policies (WHO), 2004.

Mossialos, Elias, Martin Wenzel, Robin Osborn, and Dana Sarnak, 2015 International profiles of health care systems, New York, NY: Commonwealth Fund, 2016. As of May 25, 2016: http://www.commonwealthfund.org/publications/fund-reports/2016/jan/internationalprofiles-2015

National Bureau of Economic Research, "Internet TAXSIM version 9.3," 2013. As of February 21, 2016: http://users.nber.org/ taxsim/taxsim9/

National Conference of State Legislatures, "State Partisan Composition," 2016. As of March 3, 2016: http://www.ncsl.org/research/about-state-legislatures/partisan-composition.aspx

National Health Insurance Act, H.R. 15, 111 th Cong., 1st Sess. (2009).

Newhouse, Joseph P., and The Insurance Experiment Group, Free for all? Lessons from the RAND Health Insurance Experiment: Harvard University Press, 1993.

Office of the Assistant Secretary for Planning and Evaluation, Department of Health and Human Services, Demystifying microsimulation meeting report, Washington, DC, 2012. As of March 4, 2016: http://aspe.hhs.gov/sp/reports/2013/DemystMicrosim/DemystMicrosim.pdf

, "Health insurance marketplace 2016 open enrollment period: January enrollment report," 2016. As of March 7, 2016:

http://aspe.hhs.gov/sites/default/files/pdf/167981/MarketPlaceEnrollJan2016.pdf 
Oliver, Adam, "The single-payer option: A reconsideration," Journal of Health Politics, Policy and Law, Vol. 34, No. 4, Aug, 2009, pp. 509-530.

Organization of Economic Cooperation and Development, Health at a glance 2013: OECD indicators, 2013a. As of May 5, 2014: http://www.oecd.org/health/health-systems/health-ata-glance.htm

- OECD Health Statistics, Paris, 2013 b.

Palmisano, Donald J., "The danger of single-payer health insurance," Archives of Internal Medicine, Vol. 164, No. 20, Nov 8, 2004, pp. 2281-2282.

Passel, Jeffrey S., and D'Vera Cohn, A portrait of uninauthorized immigrants in the United States, Washington, DC: Pew Research Center, 2009. As of March 17, 2016:

http://www.pewhispanic.org/2009/04/14/a-portrait-of-unauthorized-immigrants-in-theunited-states/

Passel, Jeffrey S., D'Vera Cohn, Jens Manuel Krogstad, and Ana Gonzalez-Barrera, As growth stalls, unauthorized immigrant population becomes more settled, Washington, DC: Pew Research Center, 2014. As of March 17, 2016: http://www.pewhispanic.org/2014/09/03/asgrowth-stalls-unauthorized-immigrant-population-becomes-more-settled/

Pauly, Mark V., "The incidence of health insurance costs: is everyone out of step but economists?," Industrial Relations Research Association Series Forty-First Annual Meeting, 1988, pp. 387-397.

- , Health benefits at work: An economic and political analysis of employment-based health insurance: University of Michigan Press, 1999.

Petersen, Mark, and David Muhlestein, "ACO results: what we know so far," in Health Affairsairs Blog: Health Affairs, 2014. As of January 29, 2015: http://healthaffairs.org/blog/2014/05/30/aco-results-what-we-know-so-far/

Pollack, Harold, "Medicare for All if it were politically possible would necessarily replicate the defects of our current system," Journal of Health Politics Policy and Law, Vol. 40, No. 4, Aug, 2015, pp. 923-931.

Pollin, Robert, Dean Baker, and Marc Schaberg, Securities transaction taxes for U.S. financial markets, Amherst, MA: Political Economy Research Institute, 20, 2002. As of September 13, 2015: http://www.peri.umass.edu/fileadmin/pdf/working_papers/working_papers_150/WP20.pdf

Pollin, Robert, and James Heintz, Transaction costs, trading elasticities and the revenue potential of financial transaction taxes for the United States, Political Economy Research Institute, 2011. As of September 13, 2015: http://www.peri.umass.edu/fileadmin/pdf/research_brief/PERI_FTT_Research_Brief.pdf

Pozen, Alexis, and David M Cutler, "Medical spending differences in the United States and Canada: The role of prices, procedures, and administrative expenses," Inquiry, Vol. 47, No. 2, 2010, pp. 124-134.

Reid, T. R., The healing of America: A global quest for better, cheaper, and fairer health care, New York, New York: Penguin Press, 2009.

Ringel, Jeanne S, Federico Girosi, Amado Cordova, Carter C Price, and Elizabeth A McGlynn, Analysis of the Patient Protection and Affordable Care Act (HR 3590), Santa Monica, CA: 
RAND Corporation, RB-9514, 2010. As of February 29, 2015:

http://www.rand.org/pubs/research_briefs/RB9514.html

S. 51, 2007-2008 Leg. (Wis. 2007).

S. 515, 2013 Leg. (Mass. 2013).

S. 810, 2012 Leg. (Cal. 2012).

S.B. 104 / H.B. 121, 130th Gen. Assem., Reg. Sess. (Ohio 2013).

S.B. 226, 51st Leg., 1st Sess. (N.M. 2013).

S.B. 400, 2013 Leg. (Pa. 2013).

S.B. 667, 2014 Leg. (Md. 2014).

Sanders, Bernie, "Medicare for All: leaving no one behind," January, 2016. As of February 12, 2016: http://berniesanders.com/wp-content/uploads/2016/01/Medicare-for-All.pdf

Schulmeister, Stephan, Margit Schratzenstaller, and Oliver Picek, A general financial transaction tax: Motives, revenues, feasibility and effects Vienna, Austria: Austrian Institute of Economic Research, 2008. As of October 23, 2015: http://www.wifo.ac.at/publikationen?detail-view=yes\&publikation_id=31819

Securities Industry and Financial Markets Association, U.S. bond market trading volume, 2015. As of March 7, 2016: http://www.sifma.org/research/statistics.aspx

Shaw, James C., "Oh, Canada: Comparing single-payer health care with practice in the United States," American Journal of Medicine, Vol. 118, No. 10, Oct, 2005, pp. 1064-1066.

Sheils, John F., Gary J. Young, and Robert J. Rubin, "O Canada: Do we expect too much from its health system?," Health Affairs, Vol. 11, No. 1, Spring, 1992, pp. 7-20.

Sheils, John F., and Randall A. Haught, Analysis of the costs and impact of universal health care coverage under a single payer model for the State of Vermont, Falls Church, VA: The Lewin Group Inc., 2001.

Sing, Merrile, Jessica S. Banthin, Thomas M. Selden, Cathy A. Cowan, and Sean P. Keehan, "Reconciling medical expenditure estimates from the MEPS and NHEA, 2002," Health Care Financing Review, Vol. 28, No. 1, Fall, 2006, pp. 25-40.

Slee, Vergil N., and Debora A. Slee, Health care reform terms: An explanatory glossary of words, phrases, \& acronyms used in today's U.S. "health care reform" movement, Second edition, St. Paul, Minn.: Tringa Press, 1994.

Sommers, Benjamin D., Thomas Musco, Kenneth Finegold, Munira Z. Gunja, Amy Burke, and Audrey M. McDowell, "Health reform and changes in health insurance coverage in 2014," New England Journal of Medicine, Vol. 371, No. 9, Aug 28, 2014, pp. 867-874.

Sparer, Michael S., Lawrence D. Brown, and Lawrence R. Jacobs, "Exploring the concept of single payer," Journal of Health Politics, Policy and Law, Vol. 34, No. 4, Aug, 2009, pp. 447-451.

State of Vermont Agency of Administration, Health Care Reform, Green Mountain Care: A comprehensive model for building Vermont's universal health care system, Montpelier, VT: State of Vermont, 2014. As of January 23, 2015: http://hcr.vermont.gov/sites/hcr/files/pdfs/GMC\%20FINAL\%20REPORT\%20123014.pdf 
Stone, Deborah, "Single payer: good metaphor, bad politics," Journal of Health Politics, Policy and Law, Vol. 34, No. 4, Aug, 2009, pp. 531-542.

The Official Website of the Governor of Vermont, "Gov. Shumlin details health care financing report to business and consumer advisory councils," December 17, 2014. As of December 18, 2014: http://governor.vermont.gov/node/2163

Thomson, Sarah, Robin Osborn, David Squires, and Miraya Jun, International profiles of health care systems, 2013: Australia, Canada, Denmark, England, France, Germany, Italy, Japan, the Netherlands, New Zealand, Norway, Sweden, Switzerland, and the United States, New York, New York: The Commonwealth Fund, 2013. As of July 26, 2014:

http://www.commonwealthfund.org/publications/fund-reports/2013/nov/internationalprofiles-of-health-care-systems

Thorpe, Kenneth E., "An analysis of Senator Sanders single payer plan," January 27, 2016. As of February 12, 2016: http://www.scribd.com/doc/296831690/Kenneth-Thorpe-s-analysis-ofBernie-Sanders-s-single-payer-proposal

Tuohy, Carolyn H., "Single payers, multiple systems: the scope and limits of subnational variation under a federal health policy framework," Journal of Health Politics, Policy and Law, Vol. 34, No. 4, Aug, 2009, pp. 453-496.

U.S. Internal Revenue Service, "SOI Tax Stats: Individual statistical table by size of adjusted gross income," 2013. As of November 6, 2015: http://www.irs.gov/uac/SOI-Tax-Stats--Individual-Statistical-Tables-by-Size-of-Adjusted-Gross-Income

— , "Questions and answers for the Additional Medicare Tax," 2015a. As of October 23, 2015: http://www.irs.gov/Businesses/Small-Businesses-\&-Self-Employed/Questions-andAnswers-for-the-Additional-Medicare-Tax

_ , "Questions and answers on the Net Investment Income Tax," 2015b. As of October 23, 2015: http://www.irs.gov/uac/Newsroom/Net-Investment-Income-Tax-FAQs

U.S. Securities and Exchange Commission, Select SEC and market data, fiscal 2014, Washington, DC, 2015. As of March 22, 2016: http://www.sec.gov/about/secstats2014.pdf

Uberoi, Namrata, Kenneth Finegold, and Emily Gee, Health insurance coverage and the Affordable Care Act, 2010-2016, Washington, DC: Office of the Assistant Secretary for Planning and Evaluation, Department of Health and Human Services, 2016. As of May 11, 2016: https://aspe.hhs.gov/sites/default/files/pdf/187551/ACA2010-2016.pdf

Wallace, Steven P., Jaqueline M. Torres, Tabashir Z. Nobari, and Nadereh Pourat, Undocumented and uninsured: Barriers to affordable care for immigrant populations, New York, NY: Commonwealth Fund, 2013. As of March 10, 2016:

http://www.commonwealthfund.org/publications/fund-reports/2013/aug/undocumented-anduninsured

White House Office of Management and Budget, Fiscal year 2015 historical tables: Budget of the U.S. government, Washington, DC, 2014. As of August 11, 2015: http://www.whitehouse.gov/sites/default/files/omb/budget/fy2015/assets/hist.pdf

White, Joseph, "Gap and parallel insurance in health care systems with mandatory contributions to a single funding pool for core medical and hospital benefits for all citizens in any given 
geographic area," Journal of Health Politics, Policy and Law, Vol. 34, No. 4, Aug, 2009, pp. 543-583.

Woolhandler, Steffie, Terry Campbell, and David U. Himmelstein, "Costs of health care administration in the United States and Canada," New England Journal of Medicine, Vol. 349, No. 8, Aug 21, 2003, pp. 768-775.

Woolhandler, Steffie, David U. Himmelstein, Marcia Angell, Quentin D. Young, and Physicians' Working Group Single-Payer, "Proposal of the Physicians' Working Group for Single-Payer National Health Insurance," Journal of the American Medical Association, Vol. 290, No. 6, Aug 13, 2003, pp. 798-805.

Xu, Ke, David B. Evans, Guy Carrin, and Ana M. Aguilar-Rivera, Designing health financing systems to reduce catastrophic health expenditure, Geneva, Switzerland: World Health Organization, 2005. As of December 12, 2014:

http://www.who.int/health_financing/documents/pb_e_05_2-cata_sys.pdf

Xu, Ke, David B. Evans, Kei Kawabata, Riadh Zeramdini, Jan Klavus, and Christopher J. Murray, "Household catastrophic health expenditure: a multicountry analysis," Lancet, Vol. 362, No. 9378, Jul 12, 2003, pp. 111-117.

Zweifel, Peter, and Willard G. Manning, "Moral hazard and consumer incentives in health care," Handbook of health economics, Amsterdam: North-Holland, 2000, pp. 409-459. 